\title{
De waarde van een startkwalificatie
}

\author{
Citation for published version (APA):
}

van der Velden, R. K. W., de Vries, M. R., Wolbers, M. H. J., \& van Eijs, P. W. L. J. (2002). De waarde van een startkwalificatie. Researchcentrum voor Onderwijs en Arbeidsmarkt, Faculteit der Economische Wetenschappen. ROA Reports No. 14 https://doi.org/10.26481/umarep.2002014

Document status and date:

Published: 01/01/2002

DOI:

10.26481/umarep.2002014

Document Version:

Publisher's PDF, also known as Version of record

\section{Please check the document version of this publication:}

- A submitted manuscript is the version of the article upon submission and before peer-review. There can be important differences between the submitted version and the official published version of record.

People interested in the research are advised to contact the author for the final version of the publication, or visit the DOI to the publisher's website.

- The final author version and the galley proof are versions of the publication after peer review.

- The final published version features the final layout of the paper including the volume, issue and page numbers.

Link to publication

\footnotetext{
General rights rights.

- You may freely distribute the URL identifying the publication in the public portal. please follow below link for the End User Agreement:

www.umlib.nl/taverne-license

Take down policy

If you believe that this document breaches copyright please contact us at:

repository@maastrichtuniversity.nl

providing details and we will investigate your claim.
}

Copyright and moral rights for the publications made accessible in the public portal are retained by the authors and/or other copyright owners and it is a condition of accessing publications that users recognise and abide by the legal requirements associated with these

- Users may download and print one copy of any publication from the public portal for the purpose of private study or research.

- You may not further distribute the material or use it for any profit-making activity or commercial gain

If the publication is distributed under the terms of Article $25 \mathrm{fa}$ of the Dutch Copyright Act, indicated by the "Taverne" license above, 
De waarde van een startkwalificatie

ROA-R-2002/14

R. van der Velden

R. de Vries

M. Wolbers

P. van Eijs

Researchcentrum voor Onderwijs en Arbeidsmarkt

Faculteit der Economische Wetenschappen en Bedrijfskunde Universiteit Maastricht

Maastricht, november 2002 
ISBN 90-5321-366-X

Sec02.164.doc 


\section{Inhoud}

Bladzijde

Voorwoord

1 Introductie 1

1.1 De achtergrond 1

1.2 Leeswijzer 1

2 De waarde van een opleiding 3

2.1 Het probleem 3

2.2 Theoretische invalshoeken 5

2.3 De startkwalificatie als beleidsmatig streven van de Nederlandse $\begin{array}{ll}\text { overheid } & 10\end{array}$

2.4 De OECD en de transitie van school naar werk 11

3 De startkwalificatie in de Nederlandse context 15

3.1 Wat is er bekend? 15

$\begin{array}{ll}3.2 \text { Data en methodiek } & 16\end{array}$

$\begin{array}{ll}3.3 & \text { Doorstroom naar vervolgonderwijs } \\ 3.4 & 18\end{array}$

3.4 De arbeidsmarktintrede van schoolverlaters 20

3.5 De waarde van opleidingen op niveau 2 nader bekeken 25

$\begin{array}{lll}3.6 & \text { Conclusie } & 35\end{array}$

4 De waarde van een startkwalificatie vanuit een internationaal perspectief $\quad 37$

$\begin{array}{ll}4.1 & \text { Inleiding } \\ 4.2 & \text { Onderzoeksopzet }\end{array}$

$\begin{array}{lll}4.2 & \text { Onderzoeksopzet } & 38\end{array}$

4.3 Resultaten $\quad 40$

$\begin{array}{ll}4.4 & \text { Samenvatting en conclusie }\end{array} 49$

5 Samenvatting en conclusies 53

5.1 De belangrijkste bevindingen $\quad 53$

5.2 Verschillen in uitkomsten $\quad 55$

$\begin{array}{ll}5.3 \text { Conclusies } & 57\end{array}$

6 Literatuur $\quad 59$

$\begin{array}{ll}\text { Appendix A } & 61\end{array}$ 



\section{Voorwoord}

In het Nederlandse onderwijsbeleid wordt de startkwalificatie aangemerkt als het minimale onderwijsniveau dat vereist is om een (volwaardige) plaats op de arbeidsmarkt te verwerven. Binnen het beroepsonderwijs is deze startkwalificatie gelijkgesteld aan de basisberoepsopleiding (niveau 2 in de BOL en BBL). In het rapport 'Education at a Glance' van de OECD worden deze korte beroepsopleidingen niet gerekend tot succesvolle afronding van een opleiding in het hoger secundair onderwijs (de zogeheten 'level completion'). Daarmee zou een zekere discrepantie bestaan tussen wat volgens nationale en internationale maatstaven als startkwalificatie wordt beschouwd.

Voor het Ministerie van OCenW is dit aanleiding geweest om een onderzoek te laten uitvoeren met als centrale vraagstelling: Wat is de waarde van de Nederlandse startkwalificatie zowel in de nationale als in de internationale context?

Het onderzoek bestaat uit een viertal deelonderzoeken:

1. Een controle op de indeling van de beroepsopleidingen naar de nationale opleidingsclassificatie en de conversie hiervan naar de internationale opleidingsclassificatie door het Centraal Bureau voor de Statistiek (CBS).

2. Een internationale vergelijking van opleidingsprogramma's op het niveau van de startkwalificatie naar programmaduur, -inhoud en -zwaarte door het OCTO, Universiteit Twente.

3. Een benchmarking op basis van onafhankelijke vaardigheidsmetingen (PISA, TIMMS, IALS) door het Max Goote Kenniscentrum (MGK), Universiteit van Amsterdam.

4. Een vergelijking van de externe rendementen van de startkwalificatie met opleidingen die qua niveau daar vlak onder zitten respectievelijk vlak boven zitten door het Researchcentrum voor Onderwijs en Arbeidsmarkt (ROA), Universiteit Maastricht.

De algehele projectcoördinatie berust bij drs. W. Houtkoop van het MGK.

Het voorliggende rapport doet verslag van het vierde deelonderzoek. Het vormt tevens een onderdeel van het algemene verslag dat uitgebracht wordt door het MGK.

Het onderzoek van het ROA is uitgevoerd door drs. R. de Vries, dr. M. Wolbers en drs. P. van Eijs. De projectleiding was in handen van dr. R. van der Velden.

Een woord van dank is op zijn plaats voor de leden van de begeleidingscommissie: drs. C. Bakker, drs. J. van Rijn en drs. U. Teunis (allen OCenW). Daarnaast heeft het ROA waardevolle opmerkingen ontvangen van de projectcoördinator, drs. W. Houtkoop, alsmede van de onderzoekers van de overige deelprojecten: dr. J. Brandsma (OCTO), drs. W. Bernelot Moens en drs. J. van der Valk (beiden CBS). We danken alle betrokkenen voor de plezierige samenwerking.

Maastricht, januari 2003

Prof. Dr. J.A.M. Heijke

directeur 



\section{Introductie}

\subsection{De achtergrond}

Het Nederlandse onderwijsbeleid is erop gericht om jongeren minimaal een startkwalificatie te laten behalen, dat wil zeggen een opleiding overeenkomend met niveau 2 van de kwalificatiestructuur voor de beroepsopleidende leerweg (BOL) en de beroepsbegeleidende leerweg (BBL) van het secundair beroepsonderwijs. ${ }^{1}$ Globaal betekent dit dat na het verlaten van het VMBO (voorheen VBO en MAVO) nog een beroepsopleiding moet worden gevolgd via de BOL of de BBL met een minimale opleidingsduur van 2 jaar (voorheen 2-jarig kmbo respectievelijk primair leerlingwezen). De startkwalificatie (of het niveau van basisberoepsbeoefenaar) wordt gezien als het niveau dat minimaal noodzakelijk is om op een goede manier te kunnen functioneren op de zich snel veranderende arbeidsmarkt.

In de nieuwe internationale classificatie van opleidingen (ISCED 1997) worden de Nederlandse niveau 2 opleidingen van het secundair beroepsonderwijs ingedeeld als niveau $3 \mathrm{C}$ short. Ofschoon $3 \mathrm{C}$ short behoort tot het niveau van 'upper secondary education', wordt dit in publicaties van de OECD niet beschouwd als 'level completion'. Van 'level completion' oftewel volledige afronding van het secundair onderwijs is sprake wanneer, gezien naar nationale maatstaven, een opleiding zodanig is afgerond dat een leerling hetzij toegang heeft verkregen tot het tertiair onderwijs dan wel goed opgeleid de arbeidsmarkt kan betreden. Voor Nederland ligt de grens van 'level completion' bij opleidingen op minimaal niveau 3 van de kwalificatiestructuur (de zogeheten vakopleidingen). Voor Engeland en Frankrijk is echter in OECD verband een uitzondering gemaakt. Daar worden opleidingen op niveau $3 \mathrm{C}$ short wel als 'level completion' beschouwd.

De Nederlandse overheid ziet zich voor het probleem gesteld dat wat in Nederland als een startkwalificatie wordt beschouwd, door de OECD impliciet niet als zodanig wordt erkend. Aangezien juist het streven van de overheid erop is gericht om iedereen minimaal een startkwalificatie te laten behalen, en de betreffende opleidingen in het Nederlandse onderwijssysteem ook getalsmatig een belangrijke plaats innemen, is er veel aan gelegen om helderheid te verschaffen over de feitelijke waarde van de Nederlandse startkwalificatie. Aan het ROA is gevraagd om een empirisch onderzoek te verrichten waarbij zowel de nationale situatie wordt belicht, als een vergelijking plaats vindt met andere landen (waaronder het Verenigd Koninkrijk en Frankrijk). In dit rapport wordt hiervan verslag gedaan.

\subsection{Leeswijzer}

De opbouw van het rapport is als volgt. In hoofdstuk 2 wordt ingegaan op de vraag hoe de waarde van een opleiding bepaald kan worden en op welke wijze een

1. Ook de tweede fase VO (diploma HAVO of VWO) leidt tot een startkwalificatie, maar blijft hier - gezien de nadruk op het secundair beroepsonderwijs - buiten beschouwing. 
demarcatie criterium gevonden kan worden om een minimum niveau als startkwalificatie te bepalen. Enerzijds zal worden ingegaan op de vraag in hoeverre arbeidsmarkttheorieën houvast bieden voor een dergelijke demarcatie. Anderzijds zal worden nagegaan wat de argumenten zijn geweest in het beleid, zowel van OCenW als OECD om een bepaald niveau als startkwalificatie resp. 'level completion' te definiëren.

In hoofdstuk 3 zal de waarde van de Nederlandse startkwalificatie (niveau 2 in de WEB) worden bekeken door die te vergelijken met zowel de opleidingen die daar vlak boven zitten (de opleidingen op niveau 3 en 4 ) als de opleidingen die er onder zitten (niveau 1 en VBO). Deze analyse vindt plaats op basis van schoolverlatersonderzoek van het ROA. Uitgaande van de premisse dat niveau 3 en 4 in ieder geval wel een startkwalificatie opleveren en het VBO en niveau 1 niet, kan aan de hand van de plaats die de opleidingen op niveau 2 innemen worden nagegaan of ze meer op de ene groep dan wel meer op de andere groep van opleidingen lijken. Wanneer de waarde van een startkwalificatie op de arbeidsmarkt niet wezenlijk verschilt van opleidingen die niet als startkwalificatie worden beschouwd, terwijl er wel een duidelijk verschil is met de opleidingen op niveau 3 en 4 , kan inderdaad getwijfeld worden aan de vraag of niveau 2 wel een adequate startkwalificatie biedt.

In hoofdstuk 4 wordt de waarde van de Nederlandse startkwalificatie bepaald door de relatieve positie van gediplomeerden van niveau ISCED $3 \mathrm{C}$ short internationaal te vergelijken. Dit gebeurt op basis van gegevens uit de European Union Labor Force Surveys (EU LFS). Ook hier is het ijkpunt weer: hoe verhoudt de positie van niveau ISCED 3C short zich ten opzichte van de opleidingen die daar vlak boven, respectievelijk vlak onder zitten? De referentie voor de Nederlandse opleidingen op niveau ISCED 3C short zijn nu de buitenlandse opleidingen op niveau ISCED 3C short, waarbij tevens een vergelijking plaats vindt met andere opleidingen op niveau ISCED 3 (3A, 3B en 3C long) en met opleidingen op niveau ISCED 2.

Hoofdstuk 5 besluit met de conclusies. 


\section{De waarde van een opleiding}

\subsection{Het probleem}

Het (beleidsmatig) streven iedereen minimaal een startkwalificatie te laten behalen, impliceert de veronderstelling dat deze startkwalificatie noodzakelijk is om een volwaardige rol in de samenleving te vervullen. Met andere woorden: de startkwalificatie is de sleutel tot een (goede) baan, een volwaardig inkomen, een volwaardige sociale plek in de samenleving, etc. De term is voor het eerst geïntroduceerd in het advies van de Commissie Rauwenhoff (1990) en is vervolgens door het Ministerie van OCenW tot beleidsnorm verheven. De waarde van een startkwalificatie zal in dit onderzoek worden opgevat als de waarde van een opleiding in de doorstroommogelijkheden naar de arbeidsmarkt, de kansen op werk en de kwaliteit van het werk (waaronder beloning). De focus is derhalve gericht op de opbrengsten van een opleiding. Impliciet wordt daarmee verondersteld dat opleidingen die beogen een startkwalificatie te leveren minimaal bepaalde opbrengsten moeten genereren.

Ofschoon in het Nederlandse onderwijsbeleid gekozen is voor een heldere operationalisering van het begrip startkwalificatie (namelijk een opleiding op niveau 2 in BOL of BBL, resp. HAVO of VWO), is de inhoudelijke onderbouwing ervan diffuser. Nijhof \& Streumer (1994) wijzen in dit verband bijvoorbeeld op de erg brede en open definities die gegeven werd door Droste et al. (1993): "die kwalificatiebagage die noodzakelijk is om op een bevredigende wijze maatschappelijk te functioneren" (o.c. in Nijhof \& Streumer, 1994, p.12). In de nota Een goed voorbereide start van het Ministerie wordt aangegeven dat het van belang is een beroepskwalificatie te verwerven "waarmee ze zowel een goede intrede op de arbeidsmarkt kunnen maken als een voldoende basis hebben gekregen om zich gedurende de beroepsloopbaan verder te ontwikkelen" (OCenW, 1993). Daarnaast worden eisen gesteld aan de persoonlijke en maatschappelijke kwalificaties. In deze definitie wordt al duidelijk dat de inhoudelijke onderbouwing in ieder geval twee elementen omvat: de verwerving van een bepaald niveau van competenties enerzijds en het bereiken van bepaald niveau van functioneren - of opbrengsten - anderzijds.

Het is juist het vaststellen van deze twee niveaus waarvoor het moeilijk is om een helder demarcatie criterium te geven. Een demarcatie kan in beginsel op twee gronden gebaseerd zijn (die elkaar overigens niet hoeven uit te sluiten). Dit kan geïllustreerd worden aan de hand van de figuren 2.1A en 2.1B. In figuur 2.1A wordt de relatie tussen aantal jaren scholing en het bereikte competentie niveau resp. de verwachte opbrengsten voorgesteld als een rechte lijn. Hoe hoger het aantal jaren scholing, hoe hoger het bereikte competentieniveau of hoe hoger de verwachte opbrengsten. Om in dit geval tot een demarcatie te komen moet een absoluut oordeel gegeven worden over het gewenste competentieniveau of de gewenste opbrengsten op grond van maatschappelijke overwegingen. Het zijn dergelijke absolute oordelen die doorgaans impliciet of expliciet ten grondslag liggen aan het beleid inzake de startkwalificatie, maar die we ook zien terugkeren in het beleid ten aanzien van de basisvorming of de leerplicht. De geschiedenis van de leerplicht leert 
overigens dat door maatschappelijke ontwikkelingen een dergelijke grens ook sterk kan verschuiven.

Figuur 2.1a

opbrengsten

competenties

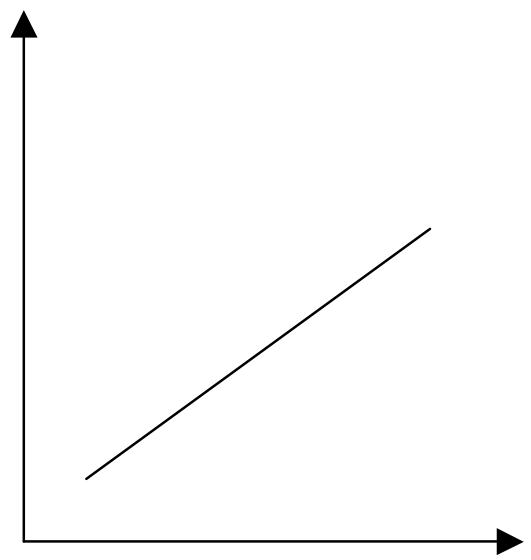

Aantal jaren scholing
Figuur 2.1b

opbrengsten

competenties

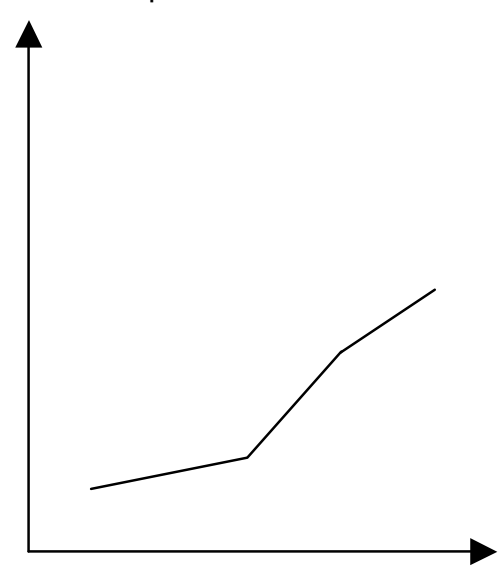

Aantal jaren scholing

De relatie tussen aantal jaren scholing en bereikt competentieniveau of verwachte opbrengsten kan echter ook discontinu verlopen. Deze situatie wordt geïllustreerd in figuur 2.1B. Het kan bijvoorbeeld zijn dat vanaf een bepaald opleidingsniveau de verwerving van relevante competenties sterk intensiveert of de opbrengsten sterk toenemen (of omgekeerd dat vanaf een bepaald aantal jaren scholing de meeropbrengsten sterk dalen). Uitgaande van gelijke kosten voor elk jaar additionele scholing, kan in dit geval een demarcatie criterium gevonden worden in het punt waar de marginale verbetering bij één jaar additionele scholing het grootst is. Met andere woorden, daar waar de relatieve sprong het grootst is.

Het bestaan van dergelijke discontinuïteiten dient op empirische gronden te worden vastgesteld. Dat is ook gelijk een voordeel in vergelijking met de absolute beoordeling omdat de laatste een bepaalde maatschappelijke consensus veronderstelt. Ook voor discontinuïteiten dient echter een theoretische legitimering gegeven te worden. Immers discontinuïteiten die in de empirie worden aangetroffen kunnen ook een toevalsbasis hebben. In dit hoofdstuk gaan we daarom eerst na of vanuit bestaande arbeidsmarkt theorieën aanknopingspunten gevonden kunnen worden voor het bestaan van dergelijke discontinuïteiten. Dit gebeurt in paragraaf 2.2.

Zoals eerder aangegeven, het al dan niet aanwezig zijn van discontinuïteiten laat onverlet dat ook op grond van algemeen maatschappelijke overwegingen de overheid een bepaald opleidingsniveau als minimum kwalificatie kan formuleren. Daarom vindt in paragraaf 2.3 een reconstructie plaats van de beleidstheorieën 
achter de concepten 'startkwalificatie' en 'level completion'. Dit gebeurt op basis van relevante beleidsdocumenten van OCenW en de OECD.

\subsection{Theoretische invalshoeken}

In deze paragraaf wordt bekeken in hoeverre in bestaande arbeidsmarkttheorieën aanknopingspunten kunnen worden gevonden voor het bestaan van continuïteit dan wel discontinuïteit in de relatie tussen aantal jaren scholing enerzijds en verworven competenties resp. opbrengsten van onderwijs anderzijds. Hiertoe passeert een aantal belangrijke theoretische stromingen op het gebied van de aansluiting tussen onderwijs en beroepspraktijk op systematische wijze de revue. Indien in de theorie aanwijzingen gevonden kunnen worden voor een discontinuïteit in de relatie tussen opleidingsniveau en arbeidsmarktpositie, dan kan dit mede als onderbouwing gebruikt worden door het beleid om iedereen minimaal op dat niveau te scholen.

\subsubsection{De human capital theorie}

De (economische) theorievorming over de relatie tussen onderwijs en arbeidsmarkt wordt gedomineerd door de human capital theorie, die zijn oorsprong vindt in Becker (1964). De human capital theorie legt een directe relatie tussen het opleidingsniveau en de productiviteit en daarmee de beloning. Hoe hoger het opleidingsniveau, hoe hoger de beloning. Dit impliceert dat de beloning alleen bepaald wordt door de opleiding (of breder: de kennis en vaardigheden) waarover iemand beschikt. De context (de baan) waarbinnen de verworven kennis en vaardigheden worden aangewend speelt geen rol. De human capital theorie is diep geworteld in de neoklassieke traditie. Dit betekent dat de allocatie op de arbeidsmarkt verondersteld wordt via het prijsmechanisme te verlopen (loonconcurrentie). In de human capital literatuur wordt daarom primair gekeken naar de beloningseffecten van het volgen van onderwijs. In een wat bredere context is de argumentatie overigens ook toepasbaar op andere (secundaire) arbeidsvoorwaarden. Benadrukt dient te worden dat er geen ruimte is voor het verklaren van verschillen in de kans op werk. Het prijsmechanisme zorgt er in de (neoklassieke) wereld van de human capital immers voor dat markten ruimen en iedereen een plek op de arbeidsmarkt kan verwerven.

Over het algemeen wordt in de human capital literatuur uitgegaan van een continue relatie tussen opleidingsniveau en beloning. Sterker nog, het rendement (in termen van beloning) van een extra jaar scholing wordt constant verondersteld (vergelijk figuur 1A). Met andere woorden, het volgen van een extra jaar scholing door een VMBO'er levert hetzelfde rendement op als het volgen van een extra jaar scholing door een academisch opgeleide. Zoals gezegd, biedt de human capital theorie bovendien geen ruimte om verschillen in de kans op werk te verklaren. Dit betekent dat in de human capital theorie geen aanknopingspunten gevonden kunnen worden die het bestaan van een discontinuïteit in de relatie tussen opleidingsniveau en arbeidsmarktpositie zouden kunnen onderbouwen. 


\subsubsection{De screening theorie}

De screening theorie kan beschouwd worden als een tegenhanger van de human capital theorie. De screening theorie legt de nadruk op baankenmerken als belangrijkste determinanten van de beloning. De in de baan vereiste kennis en vaardigheden bepalen de productiviteit en daarmee de beloning. Hoe komen mensen dan in die banen terecht? Hier speelt de opleidingsachtergrond wel een centrale rol. De opleiding vormt het criterium op basis waarvan de werkgever de mate van geschiktheid van een potentiële werknemer bepaald (met andere woorden: de opleiding fungeert als screening device). In de nauw aan de screening theorie verwante theorie van de arbeidsrij wordt een wachtrij als metafoor voor dit selectieproces gebruikt (Thurow, 1975). De werkgever plaatst de kandidaten in een wachtrij. Hoe geschikter de kandidaat, hoe beter zijn of haar plaats in de rij.

De mate van geschiktheid wordt bepaald door het gemak waarmee de kandidaat ingepast kan worden in de baan. Deze geschiktheid bepaalt de mate waarin aanvullende training nodig is en de snelheid waarmee een nieuwe werknemer zelfstandig aan de slag kan. In economische termen: hoe lager de aanpassingskosten, hoe geschikter de kandidaat. Zoals reeds gememoreerd, wordt de opleiding als graadmeter voor deze aanpassingskosten beschouwd.

Over het algemeen zal het opleidingsniveau een positieve invloed hebben op de plaats in de wachtrij. Verwacht mag worden dat een hoger opgeleide minder training nodig heeft, sneller zelfstandig aan de slag kan en een kortere inwerktijd nodig heeft dan een lager opgeleide. Lager opgeleiden komen daarmee achteraan in de wachtrij terecht. Volgens de screening theorie mag dan ook verwacht worden dat een hoger opgeleide betere arbeidsmarktkansen heeft dan een lager opgeleide. Hiermee legt de screening theorie niet alleen het accent op een ander allocatiemechanisme op de arbeidsmarkt dan de human capital theorie, maar biedt ze ook de mogelijkheid verschillen in de kans op werk te verklaren. Wanneer immers de vraag naar arbeid tekortschiet ten opzicht van het aanbod van arbeidskrachten, zullen degenen die achteraan in de wachtrij staan buiten de boot vallen en dus niet in staat zijn een baan te vinden.

Mechanismen zoals beschreven in de screening theorie kunnen ertoe leiden dat er een discontinuïteit optreedt in de relatie tussen het opleidingsniveau en de arbeidsmarktpositie. Aangezien verwacht mag worden dat de laagst opgeleiden steeds achteraan in de wachtrij terechtkomen, is het gevaar groot dat zij moeilijk een baan zullen vinden. Dit betekent dat in een situatie van economische tegenwind er een discontinuïteit kan optreden. Aan de goede kant van de 'knik' vinden we de hoger opgeleiden terug die een goede positie hebben verworven in de wachtrij en relatief makkelijk een baan hebben kunnen vinden. Aan de verkeerde kant van de knik bevinden zich de laagst opgeleiden waarvoor nauwelijks werk voorhanden is.

Een probleem is echter dat de plek van de knik afhankelijk is van de vraagaanbodverhoudingen. Hoe lager de vraag naar arbeid, hoe meer mensen er buiten de boot zullen vallen. De vraag naar arbeid is onder meer afhankelijk van 
conjuncturele schommelingen. Dit impliceert dat hoe slechter de conjuncturele situatie, hoe hoger het opleidingsniveau dat goede kansen biedt op de arbeidsmarkt. Met andere woorden: in een situatie van economische tegenwind verschuift de knik naar rechts. Dit wordt geillustreerd in figuur 2.2. Lijn A heeft betrekking op een situatie waarin de vraag naar arbeid groot is, terwijl lijn B betrekking heeft op een ongunstige economische situatie. Beleidsmatig biedt de screening theorie daarmee onvoldoende houvast. De screening theorie zou immers impliceren dat de conjunctuur voor een belangrijk deel het niveau van de startkwalificatie bepaalt.

Figuur 2.2

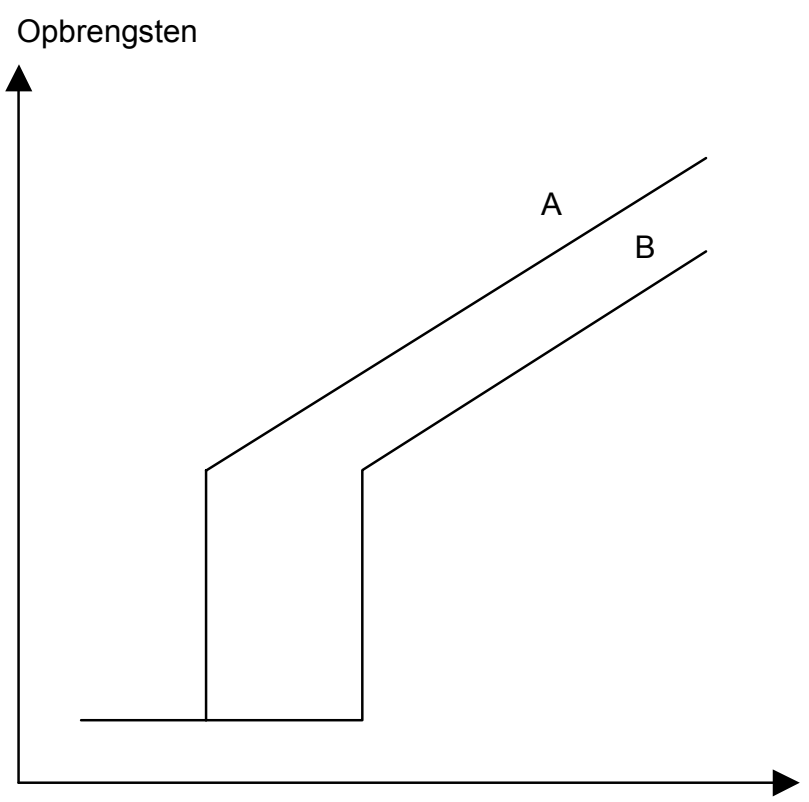

Aantal jaren scholing

\subsubsection{De job matching theorie}

Daar waar de human capital theorie de nadruk legt op persoonskenmerken en de screening theorie op baankenmerken, legt de job matching theorie de nadruk op de interactie tussen persoons- en baankenmerken (Hartog, 2000). Hoe beter de aansluiting tussen de verworven en de in de baan vereiste kennis en vaardigheden (met andere woorden: hoe beter de match), hoe beter iemand functioneert. Verwacht mag worden dat dit beter functioneren zijn weerslag vindt in de beloning. De allocatie van mensen over banen speelt hierbij dus een belangrijke rol. Om de optimale allocatie van mensen over banen te beschrijven, is het begrip comparatief voordeel geïntroduceerd. lemand heeft een comparatief voordeel in een baan wanneer hij of zij in de betreffende baan relatief het best presteert vergeleken met anderen.

Wat is het belang van de job matching theorie voor het thema van dit onderzoek? Op de eerste plaats onderstreept de job matching theorie het belang van ontwikkelingen aan de vraagzijde van de arbeidsmarkt voor het onderwijs. In het bijzonder kan 
hierbij gewezen worden op de toenemende opleidingseisen als gevolg van onder meer technologische en organisatorische ontwikkelingen. Dit upgradingsproces stelt daarmee steeds hogere eisen aan het onderwijs. Het impliceert tevens dat verwacht mag worden dat lager opgeleiden het steeds moeilijker zullen krijgen. De job matching theorie kan daarmee het belang van een startkwalificatie onderstrepen.

Op de tweede plaats biedt het begrip comparatief voordeel mogelijkheden om de discontinuïteit in de relatie tussen opleidingsniveau en arbeidsmarktpositie te onderbouwen. Verwacht mag worden dat de laagst opgeleiden een comparatief voordeel hebben in banen waarvoor nauwelijks of geen scholing vereist is. Mede in het licht van de upgrading van opleidingseisen is het belang van ongeschoolde arbeid voor de Nederlandse economie sterk afgenomen. De laagst opgeleiden dreigen daarbij dus buiten de boot te vallen. Ook hier is echter het probleem dat ook vraag-aanbodverhoudingen een rol spelen. Met name in een ongunstig economisch klimaat zullen de laagst opgeleiden moeite hebben een baan te vinden. Is de vraag naar arbeid daarentegen groot dan zullen lager opgeleiden een comparatief voordeel behalen in banen waarvoor enige scholing vereist is en kunnen zij dus wel een plekje op de arbeidsmarkt verwerven. Bovendien kan met de job matching theorie, in tegenstelling tot de screening theorie, aannemelijk gemaakt worden dat de arbeidsmarktpositie van hoger opgeleiden ook slechter kan zijn dan die van lager opgeleiden. Zo hebben bijvoorbeeld sociale wetenschappers op academisch niveau op geheel andere segmenten van de arbeidsmarkt een comparatief voordeel dan bijvoorbeeld zorgopgeleiden op MBO-niveau. Het is dus, afhankelijk van de vraagaanbodverhoudingen op de relevante arbeidsmarktsegmenten, heel goed mogelijk dat de werkloosheid onder sociale wetenschappers hoger is dan onder de zorgopgeleiden.

Net als de screening theorie biedt de job matching theorie daarmee beleidsmatig onvoldoende houvast. Ook de job matching theorie zou immers impliceren dat de aan conjuncturele schommelingen onderhevige vraag-aanbodverhoudingen op specifieke segmenten van de arbeidsmarkt voor een belangrijk deel het niveau van de startkwalificatie bepalen.

\subsubsection{Segmenteringstheorieën}

De notie dat de arbeidsmarkt niet als één geheel kan worden beschouwd, maar dat er sprake is van arbeidsmarktsegmenten met hun eigen allocatiemechanismen, is het uitgangspunt van een groot aantal theorieën over het functioneren van de arbeidsmarkt. Voorbeelden zijn de insider-outsider-theorie, en de theorie van de interne arbeidsmarkt.. Elk van deze theorieën heeft zijn eigen invalshoek. In het kader van dit onderzoek is vooral de theorie van Lutz en Sengenberger (1974) interessant, omdat daarin een relatie wordt gelegd tussen de allocatiemechanismen in de verschillende segmenten en de vereiste kwalificaties. Lutz en Sengenberger (1974) stellen dat er sprake is van drie segmenten: (1) de bedrijfsspecifieke deelmarkt (grofweg overeenkomend met het in de Angelsaksische literatuur gebruikte begrip interne arbeidsmarkt), (2) de beroepsspecifieke deelmarkt of 
vakdeelmarkt en (3) de niet-specifieke deelmarkt ("Jedermanns Qualifikation”, grofweg overeenkomend met het begrip secundaire arbeidsmarkt).

In bedrijfsspecifieke deelmarkten spelen bedrijfsspecifieke vaardigheden een belangrijke rol. Deze specifieke vaardigheden bieden de werkgever de mogelijkheid de werknemer aan zich te binden. De werknemer kan binnen het bedrijf een loopbaan opbouwen. Vanuit de optiek van de werkgever heeft het initieel onderwijs vooral als taak cognitieve vaardigheden aan te leren. Deze cognitieve vaardigheden stellen de werknemer in staat binnen het bedrijf te functioneren en zich de noodzakelijke bedrijfsspecifieke vaardigheden eigen te maken. Het opleidingsniveau bepaalt voor een belangrijk deel het niveau van de aangeleerde cognitieve vaardigheden. Een opleiding van minstens middelbaar niveau is daarom essentieel om toegang te krijgen tot de bedrijfsspecifieke deelmarkten.

Vakdeelmarkten omvatten banen waarvoor beroepsspecifieke vaardigheden van groot belang zijn. De inhoud van de baan verschilt met name tussen beroepen en veel minder tussen bedrijven. De doorgroeimogelijkheden zijn over het algemeen geringer dan in interne arbeidsmarkten. Vanuit de optiek van de vakdeelmarkt heeft het onderwijs (waartoe ook de duale opleidingen gerekend moeten worden) dan ook vooral als taak beroepsspecifieke vaardigheden aan te leren. Een beroepsopleiding is essentieel om toegang te krijgen tot een vakdeelmarkt en nationale standaardisering van de eindtermen van deze opleidingen waarborgt de mobiliteit tussen bedrijven.

De niet-specifieke deelmarkt omvat de banen waarvoor geen of uitsluitend zeer basale kennis en vaardigheden worden vereist. Vaak betreft het dan ook werk dat door laag opgeleiden wordt verricht. Over het algemeen zijn de arbeidsvoorwaarden aanzienlijk slechter dan in de bedrijfsspecifieke en de vakdeelmarkten. De lonen zijn laag, de baanzekerheid is vaak gering en er zijn nauwelijks doorgroeimogelijkheden.

Dit onderscheid tussen bedrijfsspecifieke deelmarkten, vakdeelmarkten en nietspecifieke deelmarkten onderstreept het belang van een goed en voor iedereen toegankelijk (middelbaar) beroepsonderwijs. Onderwijs op middelbaar of hoger niveau is essentieel om de schoolverlaters de algemene cognitieve vaardigheden mee te geven die hem of haar toegang verschaffen tot bedrijfsspecifieke deelmarkten. Beroepsspecifieke kwalificaties reguleren daarentegen de toegang tot vakdeelmarkten. Wanneer een schoolverlater in het initieel onderwijs noch de gewenste algemene cognitieve vaardigheden, noch de gewenste beroepsspecifieke vaardigheden heeft verworven, is de kans groot dat hij of zij terechtkomt op de nietspecifieke deelmarkt waar nauwelijks een beroep wordt gedaan op algemene of beroepsspecifieke vaardigheden.

Daarmee biedt de segmentatietheorie van Lutz en Sengenberger (1974) een mogelijke onderbouwing voor het bestaan van discontinuïteiten in de relatie tussen opleidingsniveau en arbeidsmarktpositie. De knik ligt daarbij rond het opleidingsniveau dat de schoolverlater toegang verschaft tot de bedrijfsspecifieke deelmarkten en/of de vakdeelmarkten. Op de niet-specifieke deelmarkt is er immers sprake van 
aanzienlijk slechtere arbeidsvoorwaarden dan op de bedrijfsspecifieke deelmarkten en vakdeelmarkten.

\subsubsection{Institutionele theorieën}

Ook instituties kunnen tot een discontinuïteit in de relatie tussen opleidingsniveau en arbeidsmarktpositie leiden. Een belangrijk voorbeeld vormt het minimumloon. Het minimumloon is een instrument om iedereen een bestaansminimum te garanderen. Het is daarmee een middel om een rechtvaardiger inkomensverdeling te bewerkstelligen. Het gevolg is wel dat de vrije werking van de arbeidsmarkt wordt verstoord. Het kan er bijvoorbeeld toe leiden dat het voor werkgevers onaantrekkelijk wordt om laag opgeleiden in dienst te nemen. De door de laag opgeleiden geleverde prestaties wegen in dat geval volgens de werkgever niet meer op tegen de (loon)kosten die deze arbeidskracht met zich meebrengt. Alleen een zeker prestatieniveau waarborgt in dat geval een goede arbeidsmarktpositie. De hierboven beschreven theorieën hebben laten zien dat het aannemelijk is dat opleiding een positieve invloed heeft op het prestatieniveau. Wanneer de kennis en vaardigheden iemand in staat stellen een prestatieniveau te bereiken dat, vanuit werkgeversoogpunt, het minimumloon rechtvaardigt, is de kans op het vinden van werk groot. Wanneer dat prestatieniveau niet wordt gehaald, is de kans op werk gering. Er kan daarom een discontinuïteit ontstaan in de relatie tussen opleidingsniveau en arbeidsmarktpositie. De knik ligt in dat geval rond het prestatie- of opleidingsniveau dat in balans is met het minimumloon. De zwakkere arbeidsmarktpositie manifesteert zich vooral in een lagere kans op werk, werkzekerheid of kwaliteit van het werk en niet of nauwelijks in de primaire arbeidsvoorwaarden. Deze laatste immers zijn institutioneel bepaald en laten voor de laag opgeleiden die wel werk hebben gevonden juist een relatief goede positie zien.

\subsection{De startkwalificatie als beleidsmatig streven van de Nederlandse overheid}

Vanuit maatschappelijk oogpunt wordt het (voortijdig) verlaten van het onderwijs met ten hoogste een VMBO-diploma als ongewenst beschouwd. Het overheidsbeleid is er dan ook op gericht om iedereen een zogeheten startkwalificatie te laten behalen. De term startkwalificatie wordt voor het eerst gebruikt in het rapport 'Onderwijsarbeidsmarkt: naar een werkzaam traject' van de commissie Rauwenhoff (Adviescommissie onderwijs en arbeidsmarkt, 1990). Dit rapport poogt onder meer vanuit de inzichten zoals geformuleerd in het advies van de commissie Wagner voort te bouwen in het licht van de maatschappelijke veranderingen die zich toentertijd voltrokken. Het rapport omvat een groot aantal voorstellen om de aansluiting tussen onderwijs en arbeidsmarkt te verbeteren. De commissie formuleert een aantal doelstellingen. De eerste doelstelling luidt: "een meer gelijke deelname aan onderwijs en scholing, in elk geval tot uiting komend tot en stimulering van een zekere startkwalificatie waarmee een ieder het beroepsleven kan intreden en de basis heeft om daarin verder te leren." (o.c., p. 15). De commissie geeft vervolgens ook aan welk niveau zij daarvoor in gedachten heeft: "Als minimale startkwalificatie hanteert zij een niveau vergelijkbaar met het huidige niveau primair leerlingwezen (aankomend 
vakman)." (o.c., p. 26). Het belangrijkste argument dat de commissie aandraagt voor het streven iedereen een startkwalificatie te laten behalen is een vergroting van de mobiliteit en flexibiliteit van het arbeidsaanbod: "Het investeren in scholing van lager opgeleiden kent blijkbaar een drempel. Het risico is dat werknemers in latere levensfasen onvoldoende mobiel en flexibel zijn en voortijdig met werken moeten stoppen." (o.c., p. 26). De commissie lijkt daarmee vooral de nadruk te leggen op de cognitieve vaardigheden die met een startkwalificatie kunnen worden verworven.

Zoals de titel al aangeeft staat het cognitieve aspect ook in de discussienota 'Blijvend leren' centraal (Ministerie van OCenW, 1993a). Deze, mede op de notitie 'Een goed voorbereide start' (Ministerie van OCenW, 1993b) gebaseerde nota, stelt: "Een goed fundament is nodig. Alleen daarop kan kennisverwerving op latere leeftijd cumuleren." (Ministerie van OCenW, 1993a, p. 21). In de nota wordt daarnaast een aantal andere argumenten ten tonele gevoerd. Zo wordt er gewezen op het belang van gelijke kansen voor iedereen: "De gedachte die achter de voorstellen (...) ligt, is dat het een kerntaak van de overheid is om elke (jonge) burger in de gelegenheid te stellen een kwalificatie te behalen, die hem of haar in de gelegenheid stelt vanuit een stabiele positie op de arbeidsmarkt in de samenleving te functioneren." (o.c., p. 22). De nota onderstreept daarbij het economisch en maatschappelijk belang van gelijke kansen voor iedereen: "Wanneer we er als samenleving in slagen zoveel mogelijk jongeren een dergelijke startkwalificatie te laten behalen, dan betekent dat niet alleen een grotere welvaart door betere werkgelegenheidskansen en minder inactiviteit. Het betekent ook dat middelen die nu moeten worden uitgegeven aan uitkeringen, scholing van werklozen, opvang van (werkloze) jongeren en (jeugd)criminaliteit door het kabinet op een meer positieve manier kunnen worden ingezet." (o.c., p. 22).

De nota onderbouwt dit economisch en maatschappelijk belang door te wijzen op onderzoek naar de arbeidsmarktpositie van voortijdig schoolverlaters. Dit onderzoek laat zien dat: "Globaal kan worden geconcludeerd dat het bezit van een startkwalificatie nodig is voor een aanvaardbare positie op de arbeidsmarkt." (o.c., p. 29). Hiermee sluit de nota nauw aan op het kader dat in paragraaf 2.1 van dit rapport is geschetst. De bevinding dat mensen met een laag opleidingsniveau een aanzienlijk zwakkere arbeidsmarktpositie hebben dan hoger opgeleiden, kan houvast bieden om het (beleidsmatig) streven iedereen een startkwalificatie te laten behalen inhoudelijk te onderbouwen.

\subsection{De OECD en de transitie van school naar werk}

De door de OECD uitgevoerde Thematic Review geeft een goed beeld van de inzichten en beleidsvoornemens die in internationaal opzicht zijn geformuleerd voor een succesvol beleid ten aanzien van de transitie van school naar werk (OECD, 2000). De eerste doelstelling luidt: "High proportion of young people completing a full upper secondary education with a recognised qualification for either work, tertiary study or both." (OECD, 2000, p. 31). De OECD onderstreept hiermee dat een succesvol transitiebeleid gericht dient te zijn op het iedereen laten behalen van een minimum opleidingsniveau (upper secondary education). 
Vervolgens passeren de voorwaarden voor een succesvol transitiebeleid de revue. Het gaat hierbij om de notie dat "education, employment and social policies can make a significant difference in laying effective foundations for lifelong learning, in dealing with the transition problem of those most at risk of being excluded, and in enhancing both economic effectiveness and social equity." (o.c., p. 14). Kijkende naar het onderwijssysteem lijkt de leerweg waarlangs upper secondary education wordt gevolgd (leerlingwezen, beroepsonderwijs of algemeen onderwijs) niet zozeer de sleutel tot een succesvolle transitie. Waar het vooral om gaat is dat "young people have available to them learning pathways and qualification frameworks that are clearly defined, well organised and open, designed and developed in a lifelong learning perspective, with effective connections to post school destinations, wether work or further study." (o.c., p. 15). Hoewel de gevolgde leerweg er wat minder toe doet is het wel belangrijk een mix van verschillende leerwegen aan te bieden. Bovendien is het wenselijk dat er makkelijk geswitcht kan worden tussen de verschillende leerwegen.

Een dergelijk 'flexibel' systeem voor het upper secondary education vergroot op verschillende manieren de kans dat jongeren met een zeker kwalificatieniveau het onderwijs verlaten. Of zoals de OECD het stelt: "young people will have available to them a wide variety of general, technical and vocational education options, developing both work-related competencies and personal and social skills." (o.c., p. 15). Op de eerste plaats biedt een dergelijk systeem de jongeren een breed scala aan keuzemogelijkheden. Hierdoor kan iedereen de leerweg kiezen die het best bij hem of haar past waardoor de kans op uitval wordt verkleind. Op de tweede plaats vergroot het de kans dat uitvallers snel de draad weer op kunnen pakken. Het systeem fungeert op dat moment als een vangnet.

Het voltooien van een opleiding op het niveau van upper secondary education is niet alleen van belang voor een succesvolle transitie van school naar werk of een makkelijke overstap naar onderwijs op tertiair niveau. Het speelt, aldus de OECD, ook een belangrijke rol in het levenslang leren. "Providing all young people with a high quality upper secondary education that develops general, personal and workrelated knowledge and skills, and providing all with opportunities for learning outside of the classroom is a key challenge in the ability of upper secondary education to lay a better foundation for lifelong learning." (OECD, 2000, p. 22).

Niet alle diploma's van opleidingen die formeel tot 'upper secondary education' behoren worden in gezaghebbende publicaties van de OECD als 'Education at a Glance' gerekend tot het succesvol voltooien van een upper secondary education. Van 'level completion' is sprake bij een volledige afronding van het secundair onderwijs, gezien naar nationale maatstaven, op een zodanige manier dat een leerling hetzij toegang heeft verkregen tot het tertiair onderwijs dan wel goed opgeleid de arbeidsmarkt kan betreden. Voor Nederland ligt de grens van 'level completion' bij opleidingen op minimaal niveau 3 van de kwalificatiestructuur (de zogeheten vakopleidingen). Voor Engeland en Frankrijk is echter in OECD verband een uitzondering gemaakt. Daar worden opleidingen op niveau $3 \mathrm{C}$ short wel als 'level completion' beschouwd. 
De uitzonderingsposities van deze landen wordt als volgt beargumenteerd: "There is a clear distinction in France between the ISCED 3C short level (...) and the higher levels which group together $3 \mathrm{C}$ long, $3 \mathrm{~B}$ and $3 \mathrm{~A}$ programmes (...). For France therefore, students who have successfully completed secondary education and those who have a level of qualification corresponding to a short ISCED 3C programme are considered to have completed the ISCED 3 level." (OECD, 2001, p. 343). Voor het Verenigd Koninkrijk luidt de argumentatie: "United Kingdom attainment data at upper secondary level (ISCED 3) include a sizeable proportion of persons (about 7 per cent of the population) whose highest level of attainment will in general have been reached at age 16 . Although the programmes which they have been do not formally satisfy the duration criterion for the completion of ISCED level 3, they can lead to a qualification (5 A-C grades in GCSEs) that the United Kingdom considers to be at the same attainment level as that conferred by completion of a number of programmes which do satisfy the ISCED criterion. In other words, the usual ISCED classification criteria have been relaxed for this group, for reasons of consistency with the national structure." (OECD, 2001, p. 343). 



\section{De startkwalificatie in de Nederlandse context}

\subsection{Wat is er bekend?}

De grote prioriteit die in de afgelopen jaren in het Nederlands onderwijsbeleid is gegeven aan het behalen van een startkwalificatie zou doen vermoeden dat de ontwikkeling hiervan op alle mogelijke niveaus gemonitord zou worden. Dit blijkt echter slechts ten dele het geval te zijn. Zo is er betrekkelijk weinig zicht op de vraag hoeveel jongeren uit een leeftijdscohort nu wel of niet een startkwalificatie behalen. Dit wordt veroorzaakt door het feit dat in de belangrijkste onderwijsstatistiek, de Onderwijsmatrices van het CBS, en daarop gebaseerde berekeningen, zoals de Referentieramingen, wel de overgangen van tijdstip $T$ naar tijdstip $T+1$ in kaart gebracht worden, maar geen longitudinale informatie op individueel niveau beschikbaar is. Dat houdt in dat op basis hiervan geen uitspraak gedaan kan worden welk percentage van degenen die het onderwijs verlaten in een later stadium alsnog een diploma in vervolgonderwijs behalen. Dat heeft tot gevolg dat de voortijdige uitstroom systematisch wordt overschat, omdat onvoldoende rekening gehouden kan worden met latere terugkeer. ${ }^{2}$ De invoering van het onderwijsnummer moet hierin verandering brengen en zal het voor het eerst mogelijk maken om systematisch de onderwijsloopbaan van individuele leerlingen te volgen en te bepalen wat de kans is voor jongeren uit een leeftijdscohort om wel of niet een startkwalificatie te behalen. ${ }^{3}$

Cijfers over de kans om een startkwalificatie te halen zijn dus gebaseerd op schattingen, waarbij soms gebruik wordt gemaakt van databronnen die niet primair voor dat doel ontworpen zijn. Cijfers hieromtrent zijn onder meer gepresenteerd in de recente evaluatie van de WEB met betrekking tot toegankelijkheid, intern rendement en de doorstroom naar de arbeidsmarkt (Van der Velden, 2001). In dat rapport presenteren De Jong en Berkebosch (2001) een analyse over de ontwikkeling van het aandeel jongeren dat geen startkwalificatie heeft behaald en ook geen onderwijs meer volgt. De cijfers zijn gebaseerd op de Enquête Beroepsbevolking (EBB) van het CBS. Daaruit komt naar voren dat van de groep 15-24 jarigen het percentage jongeren dat geen startkwalificatie heeft behaald én op dit moment ook geen onderwijs volgt, gezakt is van $20 \%$ in 1995 naar $17 \%$ in 1997 en 1998, om vervolgens in 1999 weer te stijgen naar 18\%. De stijging blijkt vooral voor rekening te komen van het groeiend aandeel autochtone jongeren dat het onderwijs verlaat zonder een startkwalificatie te behalen. Recente cijfers van OCenW laten zien dat het hier om een toevallige uitschieter gaat en dat de cijfers over 2000 en 2001 weer een lichte daling laten zien (OCenW, 2002). Ook in deze analyse kan echter geen

2. Onderzoek onder schoolverlaters van het VBO en MAVO laat zien dat van degenen die in eerste instantie geen vervolgonderwijs doen, maar direct naar de arbeidsmarkt zijn gegaan, $11 \%$ vijf jaar later alsnog een diploma in vervolgonderwijs heeft behaald (Van Eijs en Farag, 2002).

3. In het landbouwonderwijs is dat al langer mogelijk omdat daar reeds sinds 1986 door de voltijdse agrarische opleidingen gegevens over individuele deelnemers worden aangeleverd aan een centraal bestand en sinds 1993 door het agrarisch leerlingwezen. 
antwoord gegeven worden op de vraag welk percentage van een leeftijdscohort een startkwalificatie behaalt. Anders geformuleerd, weliswaar kan de relatieve verandering over de jaren heen goed vergeleken worden, aan de absolute percentages kan geen bijzondere betekenis worden gegeven.

Ook over de effecten van het al dan niet hebben van een startkwalificatie is betrekkelijk weinig informatie direct beschikbaar of toegankelijk. Een van de belangrijkste informatiebronnen over de overgang van school naar werk, de jaarlijkse publicatie Schoolverlaters tussen onderwijs en arbeidsmarkt van het ROA, publiceert weliswaar heel gedetailleerde informatie per opleiding, maar levert niet direct inzicht in de vraag of een startkwalificatie zich onderscheidt van de andere niveaus. Dit komt omdat in de presentatie van de geaggregeerde cijfers, de opleidingen op niveau 1 en 2 worden samengenomen, evenals de opleidingen op niveau 3 en 4 . Hetzelfde geldt voor de analyse die Wolbers (2001) met behulp van deze schoolverlatersgegevens heeft verricht ten behoeve van de eerder genoemde evaluatie van de WEB. De analyse van Wolbers had betrekking op de uitstroomcohorten van de BOL vanaf 1990/1991 tot en met 1997/1998. Hij concludeert dat in het algemeen de transitie van het bve naar de arbeidsmarkt succesvol verloopt, maar tekent daarbij wel aan dat de positie van de mbo'ers duidelijk beter is dan die van de kmbo'ers. Deze conclusie wordt min of meer bevestigd in de meest recente analyse van het ROA (ROA, 2002), waaruit naar voren komt dat voor de uitstroomcohorten 1990/1991 tot en met 1999/2000 de positie van de BOL $1 / 2$ schoolverlaters relatief zwak is en meer vergelijkbaar met het VBO dan met BOL 3/4 (ROA, 2002). Voor een deel echter wordt de relatief zwakke positie van de kmbo opleidingen veroorzaakt door enkele omvangrijke 1-jarige opleidingen zoals de opleiding 'oriënteren en schakelen'. De betreffende analyses zeggen derhalve nog niets over een eventueel onderscheid tussen niveau 1 en niveau 2. De analyse in dit hoofdstuk beoogt die lacune op te vullen.

\subsection{Data en methodiek}

In dit hoofdstuk worden de opleidingen op niveau 2 vergeleken met de opleidingen die qua niveau daar vlak onder zitten (niveau 1 en VBO) en de opleidingen die er boven zitten (niveau 3 en 4). De plaats die de opleidingen op niveau 2 bij deze vergelijking innemen is een indicatie van de waarde van deze opleidingen. Uitgangspunt bij de analyse is dat opleidingen van niveau 3 en 4 in ieder geval een startkwalificatie opleveren en opleidingen op niveau 1 en het VBO niet. De discussie die zich afspeelt tussen OECD en het Nederlandse beleidsstandpunt betreft de vraag of de opleidingen op niveau 2 nu bij de eerste groep of bij de tweede groep moeten worden ingedeeld. Wanneer bij de vergelijking van de opleidingen naar voren komt dat de opleidingen op niveau 2 lijken op opleidingen van niveau 3 en 4 en zich onderscheiden van niveau 1 en het VBO, dan mag worden aangenomen dat opleidingen op niveau 2 schoolverlaters een adequate startkwalificatie biedt. Op het moment dat echter blijkt dat opleidingen op niveau 2 zich niet onderscheiden van opleidingen van lager niveau, terwijl er een duidelijk onderscheid is met opleidingen op niveau 3 en 4 mag hier aan worden getwijfeld. 
Over het algemeen zijn schoolverlaters van een hoog opleidingsniveau succesvoller op de arbeidsmarkt dan schoolverlaters van een lager opleidingsniveau. In het vorige hoofdstuk is al aangegeven dat de relatie tussen de opbrengsten van een opleiding en de opleidingsduur op zowel continu als discontinu kan verlopen. Bij een continue relatie verbetert de arbeidsmarktpositie van schoolverlaters met een vast percentage met elk jaar additionele scholing. Bij een discontinue relatie is sprake van een buitenproportionele verbetering in de arbeidsmarktpositie vanaf een bepaald opleidingsniveau. Het bestaan van een dergelijk 'knik' in de relatie geeft aan bij wel opleidingsniveau een relatief sterke winst te behalen is ten opzichte van het voorgaande niveau. Dit kan eventueel als onderbouwing worden gebruikt door het beleid om studenten minimaal op dat niveau te scholen.

De gegevens die in dit hoofdstuk worden gebruikt zijn afkomstig van het schoolverlatersonderzoek RUBS (Registratie van Uitstroom en Bestemming van Schoolverlaters) dat jaarlijks door het ROA wordt uitgevoerd. Het onderzoek heeft betrekking op schoolverlaters van het voorbereidend beroepsonderwijs (VBO), het algemeen voortgezet onderwijs (MAVO, HAVO, VWO) en het secundair beroepsonderwijs (BOL, BBL). Voor de huidige analyse worden twee recente metingen gebruikt die betrekking hebben op gediplomeerde schoolverlaters van het schooljaar 1997/1998 en 1998/1999. De schoolverlaters zijn ongeveer anderhalf jaar na het verlaten van de opleiding ondervraagd. Het voornaamste doel van het onderzoek is om de arbeidsmarktpositie van schoolverlaters gedetailleerd in kaart te brengen. Het bevat daarom informatie over verschillende aspecten van de arbeidsmarktintrede, zoals de kans op werk, de aard van het dienstverband en andere kenmerken van de gevonden baan. Daarnaast bevat het schoolverlatersonderzoek RUBS informatie over de deelname aan vervolgonderwijs en de kans op uitval in de vervolgopleiding. Ongeveer 21.000 schoolverlaters van het $\mathrm{VBO}$, de $\mathrm{BOL}$ en de $\mathrm{BBL}$ hebben meegewerkt aan het onderzoek. Tabel 3.1 vermeldt het ongegewogen en gewogen aantal respondenten per opleidingsniveau, die zijn meegenomen in de analyse. Schoolverlaters van het VBO die doorstromen naar een vervolgopleiding in de BBL zijn niet meegenomen in de analyse. Dit is gedaan om een zuiver effect te meten voor schoolverlaters van die uitsluitend met het VBO de arbeidsmarkt betreden. ${ }^{4}$

Bij de vergelijking van de opleidingen is eerst gekeken naar de doorstroommogelijkheden naar het vervolgonderwijs (deelname aan vervolgonderwijs en de kans op voortijdig verlaten van de vervolgopleiding). Vervolgens wordt ingegaan op de arbeidsmarktintrede van schoolverlaters. Aan de hand van een zestal indicatoren is de waarde van opleidingen voor schoolverlaters op de arbeidsmarkt bekeken. Het betreft de kans op betaald werk, de kans op een vaste baan, de kans op een voltijdbaan, de kans op een baan in de eigen/verwante opleidingsrichting, het niveau van het beroep en het bruto uurloon van schoolverlaters. Deze geven een goed beeld wat de opleiding oplevert voor schoolverlaters die de arbeidsmarkt betreden.

4. Bij de overige opleidingsniveaus zijn de schoolverlaters die kiezen voor een vervolgopleiding in de BBL wel meegenomen in de analyse omdat dit - in vergelijking met het VBO - een veel kleinere groep betreft. 
De vergelijking van de 'score' van opleidingen op deze acht indicatoren is weergegeven in de figuren $3.1 \mathrm{t} / \mathrm{m}$ 3.8. Vervolgens is de 'score' van de opleidingen op deze indicatoren opnieuw bepaald, maar ditmaal rekening houdend met individuele kenmerken van schoolverlaters (geslacht, leeftijd, etniciteit, gevolgde opleidingssector en het jaar van behalen van het diploma). Hierdoor kan het effect van het gevolgde opleidingsniveau zuiverder geschat worden. De resultaten van deze multivariate analyses zijn vermeld in de figuren $3.9 \mathrm{t} / \mathrm{m} 3.16$. Voor schoolverlaters van de BOL en de BBL zijn aparte analyses uitgevoerd. Dit geeft een zuiverder beeld van de vergelijking van opleidingen omdat schoolverlaters van de BOL en de BBL behoorlijk van elkaar kunnen verschillen wat betreft de deelname aan vervolgonderwijs en arbeidsmarktpositie anderhalf jaar na behalen van het diploma (vergelijk ROA, 2001).

Tabel 3.1

Ongewogen en gewogen aantal respondenten per opleidingsniveau, voor het schooljaar $1997 / 1998$ en $1998 / 1999$

\begin{tabular}{lrr}
\hline & Ongewogen & Gewogen \\
\hline VBO & 3578 & \\
BOL niveau 1 & 144 & 70382 \\
BOL niveau 2 & 1482 & 2331 \\
BOL niveau 3 & 1927 & 20345 \\
BOL niveau 4 & 11088 & 10561 \\
BBL niveau 1 & 149 & 71680 \\
BBL niveau 2 & 1246 & 2701 \\
BBL niveau 3 & 874 & 24775 \\
BBL niveau 4 & 409 & 18270 \\
& & 8823 \\
\hline
\end{tabular}

\subsection{Doorstroom naar vervolgonderwijs}

Schoolverlaters die hun opleiding met succes hebben afgerond zetten de volgende stap in hun loopbaan. Daarbij kunnen ze kiezen direct toe te treden tot de arbeidsmarkt of te kiezen voor een vervolgopleiding waarmee nieuwe kennis en vaardigheden worden opgedaan. Ook kunnen ze besluiten werken en leren te combineren in de BBL. In figuur 3.1 is zowel het percentage schoolverlaters dat kiest voor een vervolgopleiding als het percentage schoolverlaters dat besluit leren en werken te combineren in de BBL weergegeven. In het onderste deel van de figuur worden schoolverlaters BOL niveau $1 \mathrm{t} / \mathrm{m} 4$ en het VBO onderling vergeleken. In het bovenste deel van figuur 3.1 is hetzelfde gedaan voor schoolverlaters van het BBL niveau $1 \mathrm{t} / \mathrm{m} 4$ en het VBO.

Uit figuur 3.1 komt naar voren - en dat is niet verwonderlijk - dat schoolverlaters van het VBO het vaakst kiezen voor een vervolgopleiding (meer dan $80 \%$ ). Opvallender is dat zowel bij de BOL als de BBL schoolverlaters van niveau 1 en niveau 2 ongeveer even vaak kiezen voor een vervolgopleiding of een combinatie van werken en leren, terwijl schoolverlaters van niveau 3 dit minder vaak doen dan schoolverlaters van niveau 2. Blijkbaar worden opleidingen op niveau 1 en niveau 2 door schoolverlaters vaker gezien als voorbereiding op een voltijd of duale vervolgopleiding dan opleidingen 
van niveau 3. Verder geldt alléén voor de BOL dat schoolverlaters van niveau 4 ongeveer even vaak besluiten door te gaan met studeren als schoolverlaters van niveau 1 en 2. Het merendeel van de schoolverlaters van BOL niveau 4 die verder gaan studeren stroomt door naar een hbo-opleiding. Bij de BBL daarentegen is het percentage schoolverlaters dat kiest voor een vervolgopleiding het laagst voor schoolverlaters van niveau 4.

Figuur 3.1

Doorstroom naar vervolgopleiding, naar voltijd en duale vervolgopleidingen

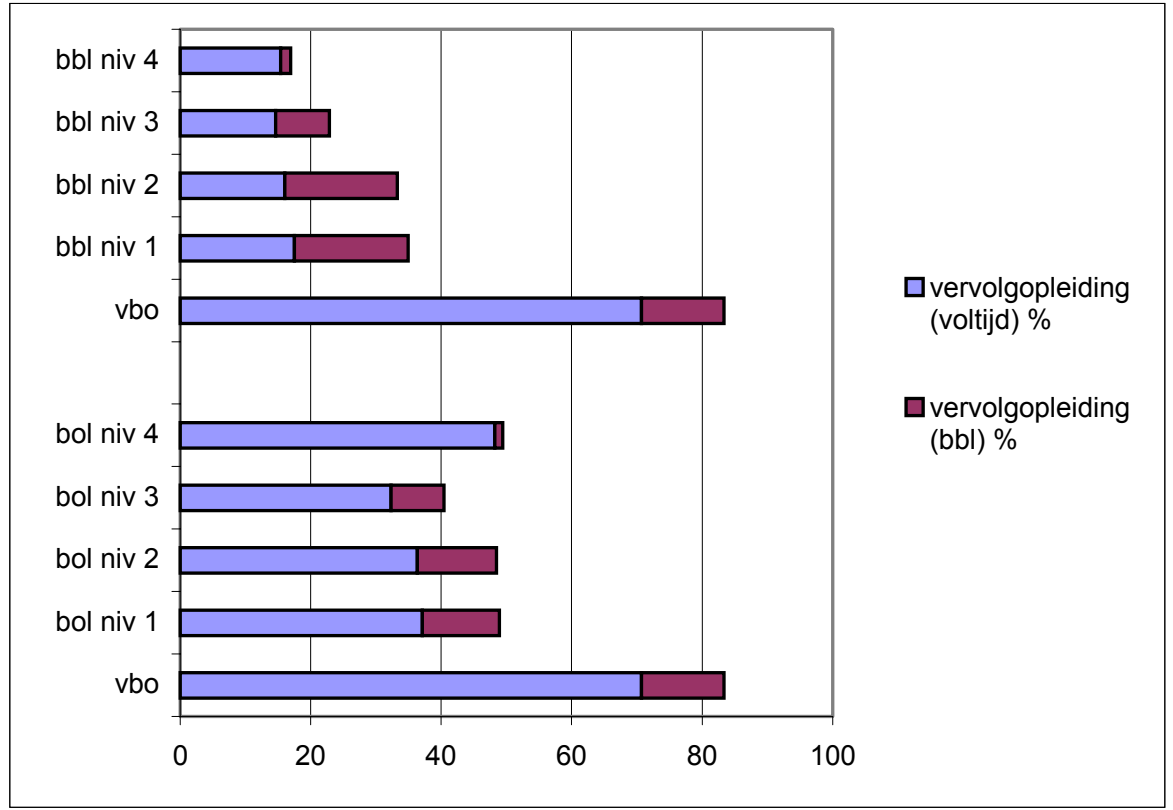

Figuur 3.2 laat voor de verder lerende schoolverlaters het percentage zien dat deze vervolgopleiding voortijdig heeft verlaten (uitval). Het gaat om schoolverlaters die de (voltijd of duale) vervolgopleiding binnen één jaar ongediplomeerd hebben verlaten. Hiervoor kunnen verschillende redenen worden gegeven; de vervolgopleiding sluit bijvoorbeeld niet goed aan bij de afgesloten opleiding, de motivatie ontbreekt om verder te gaan leren of er is een verkeerde keuze gemaakt en de schoolverlater kiest toch voor een andere studie. Dit betekent dat ook redenen die niet gerelateerd zijn aan de afgesloten opleiding er toe kunnen bijdragen dat schoolverlaters de vervolgopleiding voortijdig verlaten. Daarom moeten we voorzichtig zijn met het trekken van conclusies over de waarde van opleidingen voor verder studerende schoolverlaters op basis van een vergelijking van het percentage voortijdig schoolverlaters. Uit figuur 3.2 blijkt dat binnen de BOL verder lerende schoolverlaters van niveau 2 het vaakst de vervolgopleiding voortijdig verlaten (17\%). Zowel voor het VBO als de lagere en de hogere opleidingsniveaus van de BOL geldt dat de percentages verder lerende schoolverlaters die de opleiding voortijdig verlaten lager liggen. Voor de BBL geldt dat er een duidelijk onderscheid is tussen het VBO en BBL niveau 1 enerzijds, en BBL niveau 2, 3 en 4 anderzijds. Schoolverlaters van het VBO 
en BBL niveau 1 blijken gemiddeld vaker de opleiding voortijdig te verlaten dan schoolverlaters van een hoger opleidingsniveau. Schoolverlaters van BBL niveau 2, 3 en 4 verschillen wat dit betreft weinig van elkaar.

Figuur 3.2

Vervolgopleiding voortijdig verlaten

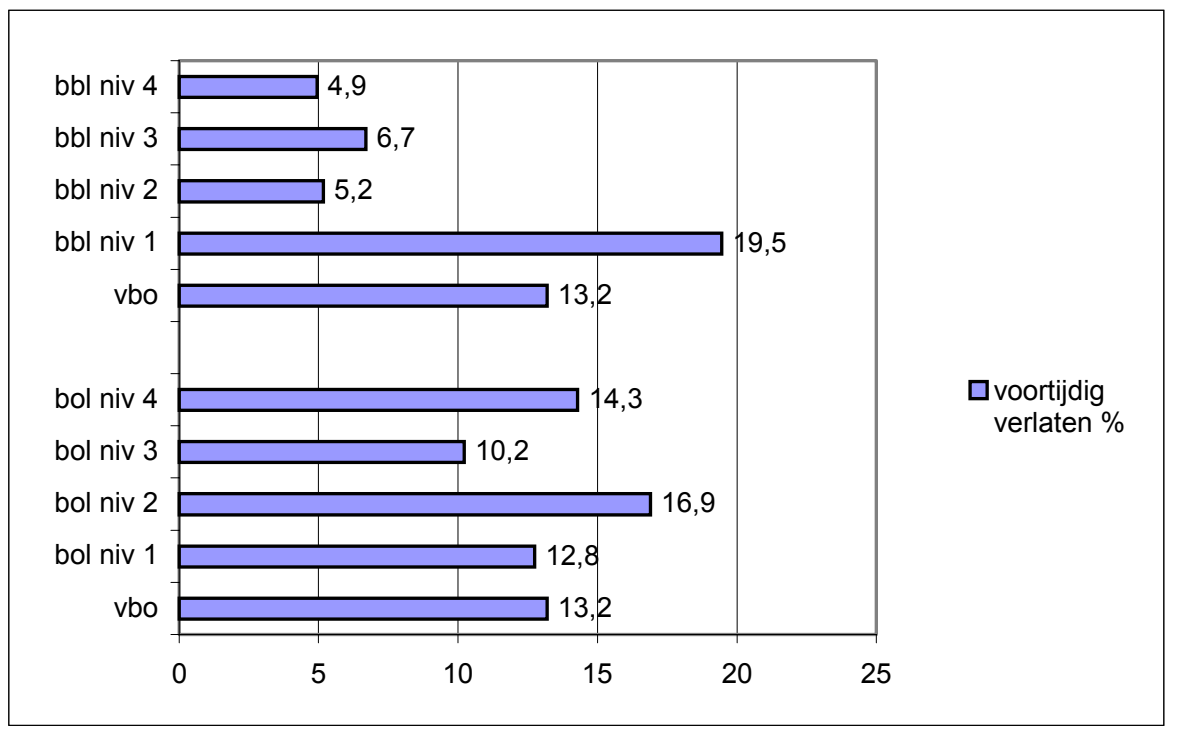

\subsection{De arbeidsmarktintrede van schoolverlaters}

De figuren $3.3 \mathrm{t} / \mathrm{m} 3.8$ geven een beeld van de arbeidsmarktpositie van gediplomeerde schoolverlaters anderhalf jaar na behalen van het diploma. Eerst wordt ingegaan op de werkgelegenheid en werkzekerheid en vervolgens wordt de kwaliteit van het werk bekeken. Bij de bespreking van de arbeidsmarktpositie van schoolverlaters mag niet worden vergeten dat na een periode van economische groei de arbeidsmarkt aan het einde van de jaren negentig uiterst krap is geworden. Schoolverlaters van de BOL en de BBL vinden daarom steeds vaker en sneller een baan (c.f. ROA, 2002). Dit blijkt ook uit figuur 3.3 waarin het werkloosheidspercentage van schoolverlaters is vermeld.

Figuur 3.3 laat zien dat het overgrote deel van de schoolverlaters die zich aanbieden op de arbeidsmarkt anderhalf jaar na behalen van het diploma betaald werk heeft gevonden. Toch bestaan er (kleine) verschillen tussen de opleidingsniveaus. Bij de BOL bestaat een onderscheid in het werkloosheidspercentage tussen schoolverlaters van BOL niveau 1 en het VBO enerzijds en schoolverlaters van BOL niveau 2, 3 en 4 anderzijds. Bij BOL niveau 1 en het VBO is rond de $5 \%$ van de schoolverlaters werkloos, terwijl voor de schoolverlaters van BOL niveau 2, 3 en 4 een werkloosheidspercentage geldt van ongeveer $2 \%$. Bij de BBL verschillen schoolverlaters van niveau 1, 2 en 3 niet veel van elkaar wat betreft het werkloosheidspercentage. Ongeveer $2 \%$ van de schoolverlaters van BBL niveau 1, 2 en 3 is werkloos. Dit percentage is lager dan voor schoolverlaters van het VBO en wat hoger dan voor schoolverlaters van BBL niveau 4, die bijna allemaal betaald werk hebben anderhalf jaar na het behalen van het diploma. 
Figuur 3.3

Werkloosheidspercentage onder gediplomeerde schoolverlaters

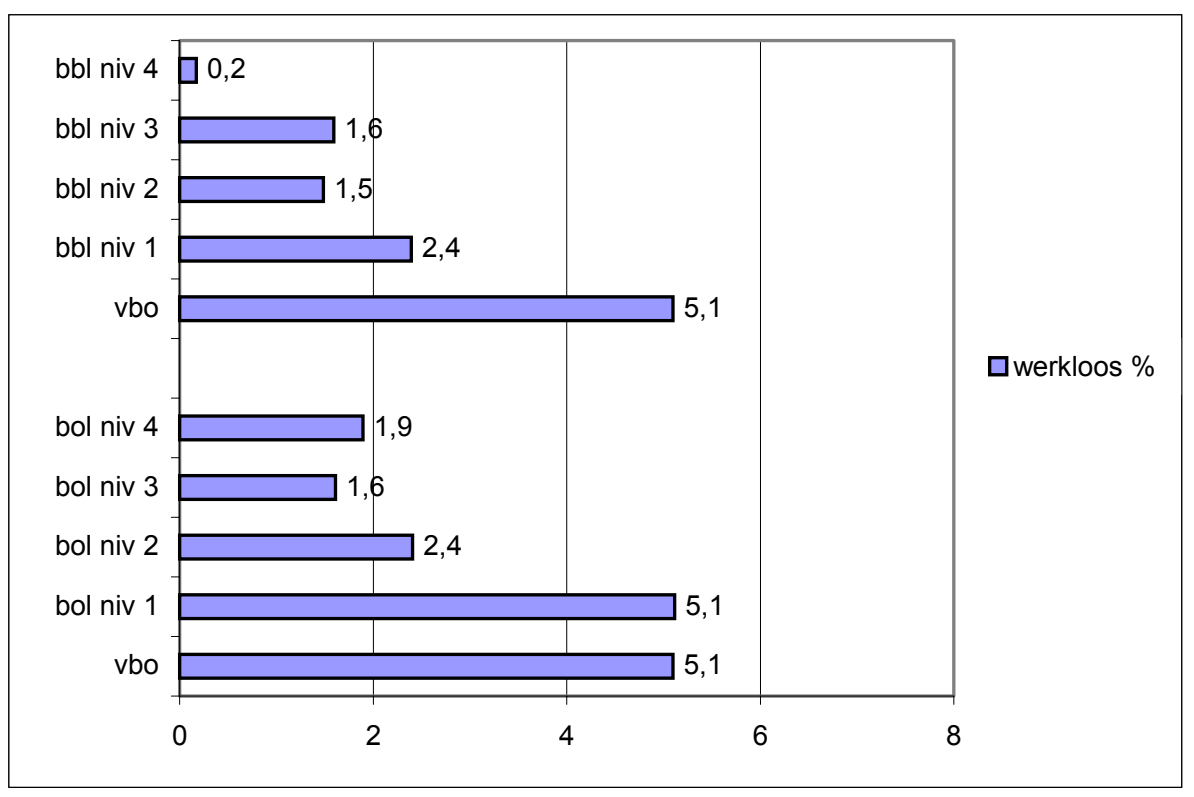

Figuur 3.4

Percentage werkzame schoolverlaters met een vast dienstverband

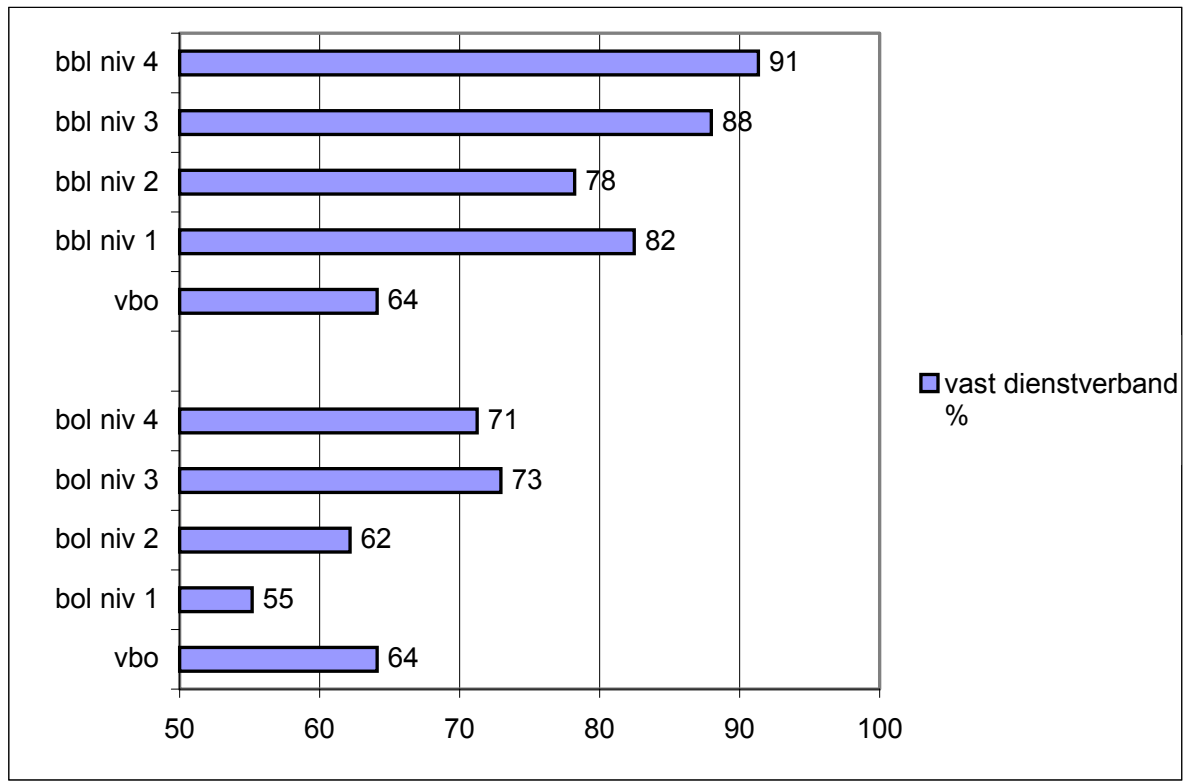

Vanwege de krappe arbeidsmarkt zijn ook de omstandigheden op de arbeidsmarkt gunstiger geworden voor schoolverlaters. Werkgevers zijn elkaar steeds meer gaan beconcurreren om goed personeel binnen te halen. Bij deze 'concurrentieslag om de werkzoekende' spelen zowel primaire als secundaire arbeidsvoorwaarden een 
belangrijke rol. De afgelopen jaren is bijvoorbeeld de werkzekerheid behoorlijk toegenomen voor schoolverlaters van de BOL en de BBL (zie ROA, 2002). Figuur 3.4 gaat in op het percentage werkzame schoolverlaters met een vast dienstverband. $\mathrm{Bij}$ de $B O L$ is er een onderscheid tussen het VBO, BOL niveau 1 en 2 enerzijds en BOL niveau 3 en 4 anderzijds. Een hoger opleidingsniveau levert hier meer werkzekerheid op. Voor de BBL geldt dat de werkzekerheid voor schoolverlaters van niveau 2 het laagst is. In vergelijking met niveau 1, 3 en 4 hebben schoolverlaters van niveau 2 minder vaak een vast dienstverband. Niettemin geldt voor elk van de onderscheiden opleidingen in het BBL dat ze beduidend meer werkzekerheid verschaffen dan VBO.

Vervolgens is in figuur 3.5 het percentage werkzame schoolverlaters met een voltijdbaan weergegeven. Bij de BOL hebben schoolverlaters van niveau 1, 2 en 3 ongeveer even vaak een voltijdbaan. Alleen schoolverlaters van BOL niveau 4 hebben vaker een voltijdbaan dan schoolverlaters van een lager opleidingsniveau. Binnen de BBL bestaat een onderscheid tussen het VBO en BBL niveau 1 enerzijds, en BBL niveau 2, 3 en 4 anderzijds. Voor VBO en BBL niveau 1 geldt dat minder dan $80 \%$ van de schoolverlaters een voltijdbaan heeft. Bij BBL niveau 2, 3 en 4 heeft tenminste $90 \%$ van de schoolverlaters een voltijdbaan. Overigens moeten we hierbij de kanttekening plaatsen dat het al dan niet hebben van een voltijd aanstelling sterk bepaald wordt door institutionele factoren als partiële leerplicht, waardoor de schoolverlaters van de lagere niveaus automatisch een lager percentage werkenden met een voltijd aanstelling kennen. Het is daarom de vraag of dit een goede indicator vormt voor de feitelijke arbeidsmarktwaarde van een opleiding.

Figuur 3.5

Percentage werkzame schoolverlaters met een voltijdbaan

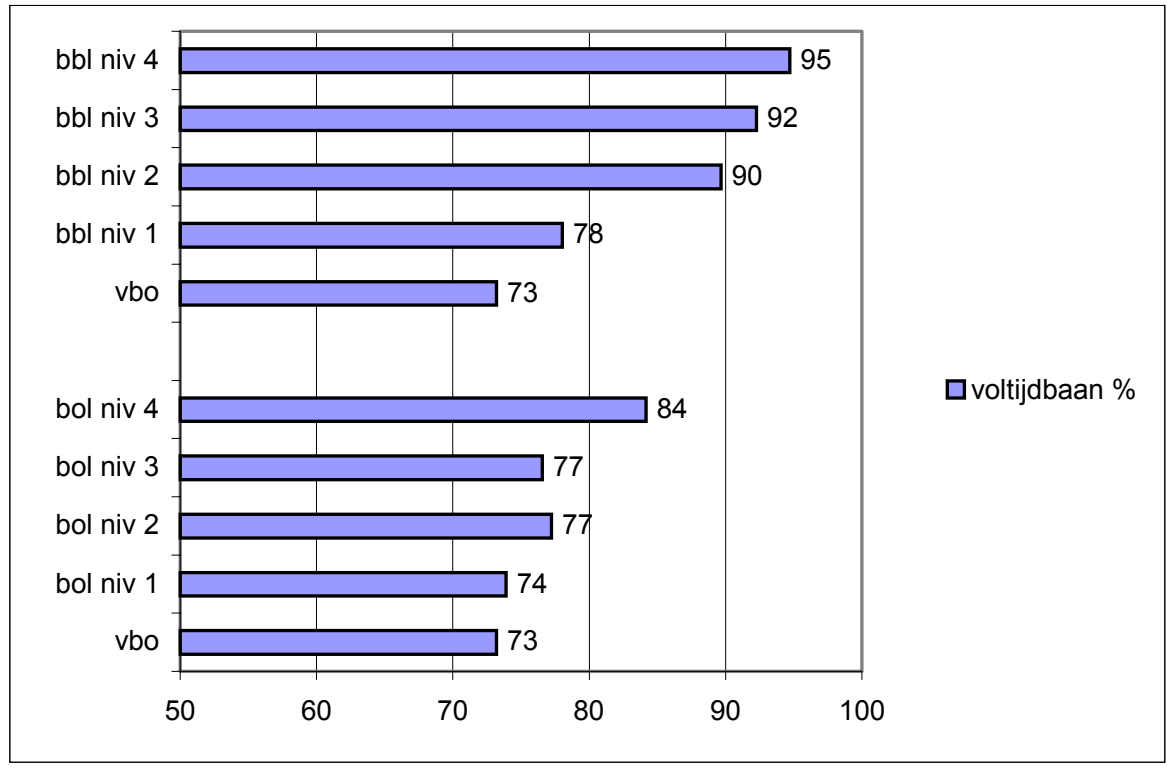


Figuur 3.6

Niveau van het beroep van werkzame schoolverlaters

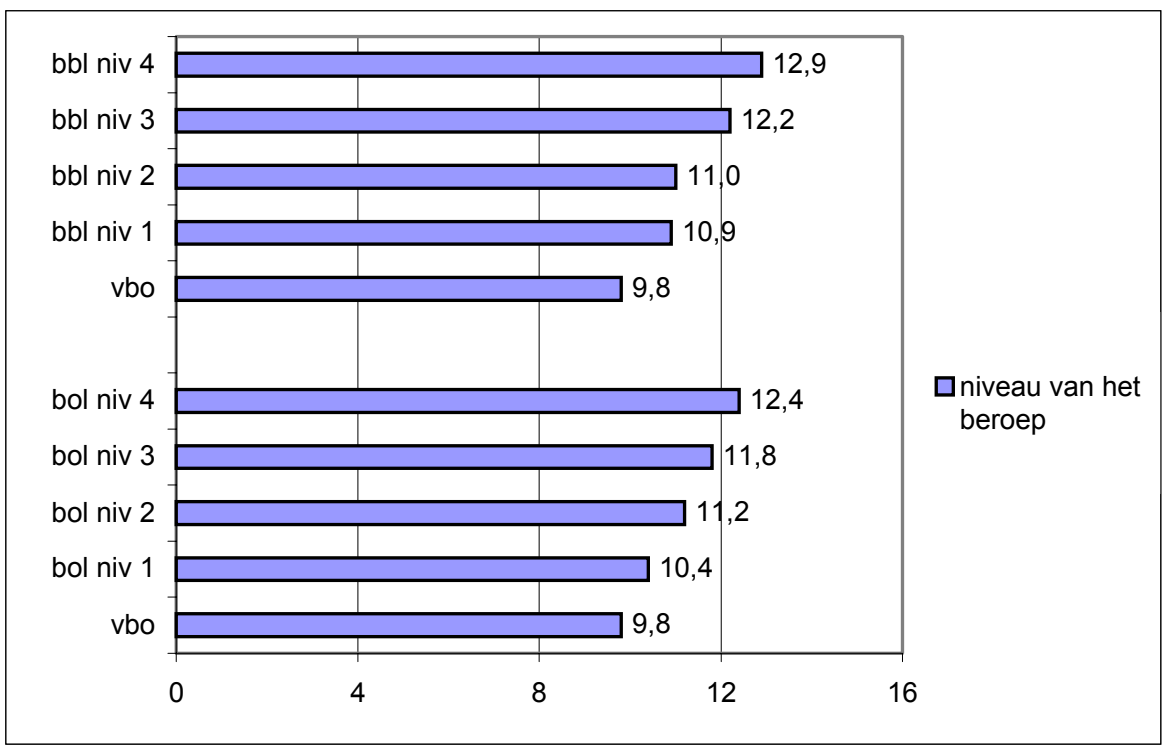

Figuur 3.6 geeft het niveau van de baan van werkzame schoolverlaters weer. Bij de meting van het beroepsniveau is gebruik gemaakt van de beroepscodes die zijn gebaseerd op de Standaard Beroepen Classificatie 1992 (SBC) van het CBS. In de SBC worden vijf niveaus onderscheiden: elementaire beroepen (vereist niveau: lager onderwijs), lagere beroepen (vereist niveau: voortgezet onderwijs, lagere trap), middelbare beroepen (vereist niveau: voortgezet onderwijs, hogere trap), hogere beroepen (vereist niveau: hoger onderwijs, eerste fase) en academische beroepen (vereist niveau: hoger onderwijs, tweede fase). Deze niveaus zijn omgerekend naar aantal jaren vereiste scholing (zie voor een verantwoording, ROA, 1999, p.60). Voor elementaire beroepen is dat 6 jaar, voor lagere beroepen 10 jaar, voor middelbare beroepen 13 jaar $^{5}$, voor hogere beroepen 17 jaar en voor academische beroepen 19 jaar.

Voor de BOL komt naar voren dat het beroepsniveau van de baan geleidelijk stijgt met de toename van het opleidingsniveau. Een toename in het opleidingsniveau levert bij de BOL ook een toename in niveau van de baan op. Voor de banen van VBO'ers is gemiddeld 9,8 jaar scholing vereist, voor de banen van de schoolverlaters van BOL niveau 4 is is dit 12,4 jaar. Dit geldt niet voor de BBL, waar opvalt dat een duidelijk onderscheid bestaat tussen de opleidingen van niveau 1 en 2 en de opleidingen van niveau 3 en 4 . Het gemiddeld beroepsniveau van schoolverlaters van niveau 1 en 2 is vrijwel gelijkwaardig en vereist elk 11 jaar, terwijl het gemiddelde beroepsniveau van schoolverlaters van niveau 3 en 4 een stuk hoger ligt. We moeten hierbij wel de kanttekening maken dat de SBC niet een zeer gedifferentieerde meting

5. Voor middelbare beroepen is uitgegaan van het gemiddelde voor beroepen waarvoor kmbo of primair leerlingwezen is vereist (12 jaar) en beroepen waarvoor mbo of voortgezet leerlingwezen is vereist (14 jaar). 
van het vereiste opleidingsniveau toelaat. Ook binnen de groep van middelbare beroepen zijn er immers nog verschillen in niveau, die in de classificatie niet worden geobserveerd.

Figuur 3.7

Percentage werkzame schoolverlaters met een baan in eigen/verwante opleidingsrichting

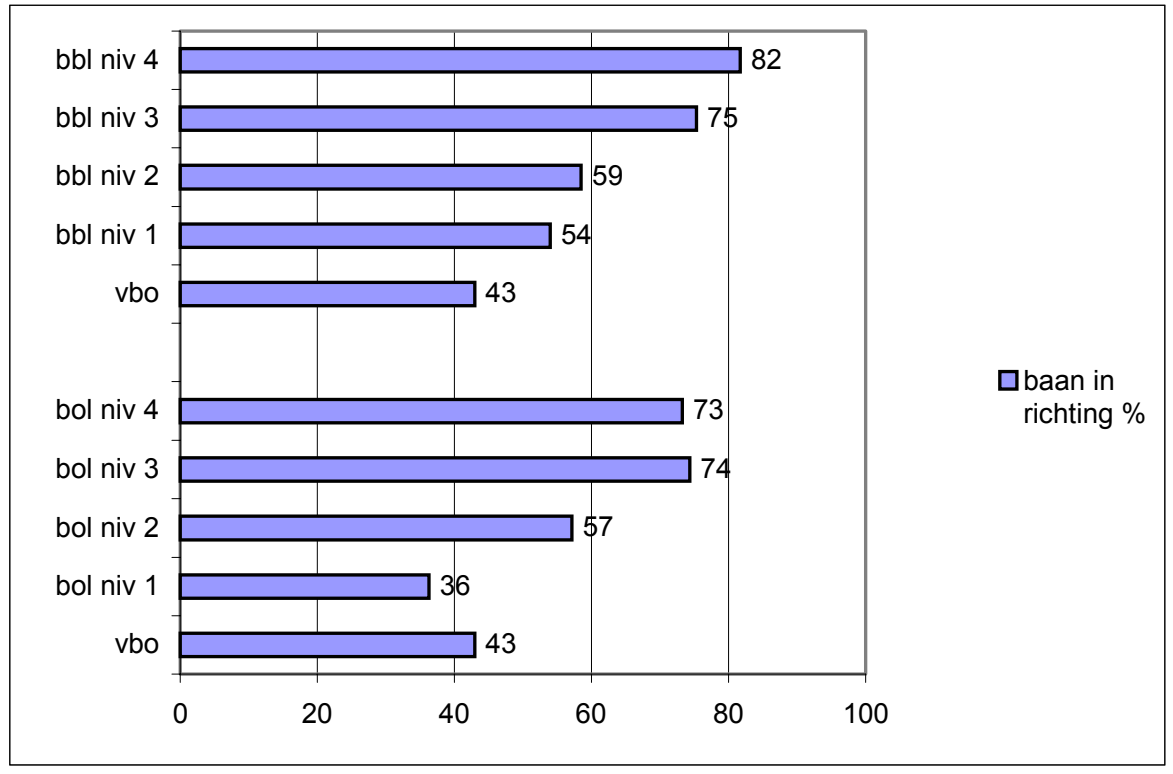

De vergelijking van het percentage schoolverlaters met een baan die aansluit bij de eigen of verwante opleidingsrichting in figuur 3.7 laat zien dat relatief weinig schoolverlaters van $\mathrm{BOL}$ niveau 1 en het $\mathrm{VBO}$, en relatief veel schoolverlaters van BOL niveau 3 en 4 een baan hebben gevonden die qua richting aansluit bij de gevolgde opleiding. Schoolverlaters van BOL niveau 2 bevinden zich wat dit betreft precies tussen beide groepen in. Voor de BBL geldt dat schoolverlaters van niveau 2 minder vaak een baan hebben gevonden die aansluit bij de gevolgde opleidingsrichting dan schoolverlaters van BBL niveau 3 en 4 . Van de schoolverlaters van BBL niveau 2 heeft ongeveer $60 \%$ van de schoolverlaters een baan die aansluit bij de gevolgde opleidingsrichting. Bij BBL niveau 3 en 4 ligt dit percentage boven de $75 \%$.

Tot slot is in figuur 3.8 het bruto uurloon van de schoolverlaters weergegeven. Het eerste wat opvalt is dat er al een behoorlijk verschil bestaat in het bruto uurloon van schoolverlaters van niveau 1 en schoolverlaters van het VBO. Dit kan overigens deels een effect zijn van leeftijdsverschillen die sterk doorwerken in het minimumjeugdloon. In de volgende paragraaf zal daarom voor leeftijd worden gecorrigeerd. Het volgende dat opvalt aan figuur 3.8 is dat zowel bij de BOL als de BBL het verschil tussen niveau 1 en niveau 2 minder groot is dan het verschil tussen niveau 2 en niveau 3. Kortom wat betreft beloning lijken schoolverlaters van niveau 2 meer op schoolverlaters van niveau 1 , dan op schoolverlaters van niveau 3. Ook hier kunnen de resultaten echter vertekend worden door leeftijdseffecten. 
Figuur 3.8

Bruto uurloon van werkzame schoolverlaters

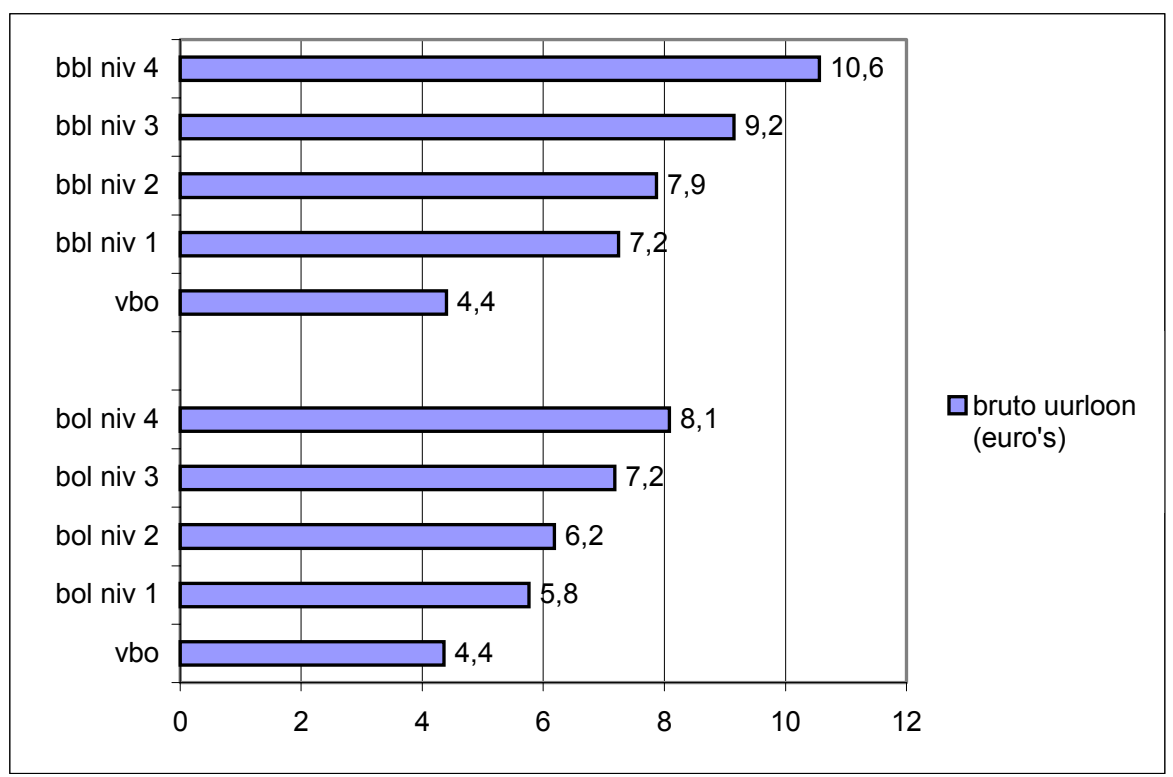

\subsection{De waarde van opleidingen op niveau 2 nader bekeken}

Bij de vergelijking van opleidingen is tot nu toe geen rekening gehouden met de individuele kenmerken van schoolverlaters. Het is goed mogelijk dat de verschillen tussen opleidingen worden veroorzaakt door bijvoorbeeld leeftijdseffecten of verschillen tussen opleidingen in het jaar van uitstroom. Daarom zijn de verschillen tussen de opleidingen opnieuw geanalyseerd, maar nu gecontroleerd voor geslacht, leeftijd, etniciteit, gevolgde opleidingssector van schoolverlaters en het jaar van behalen van het diploma. Onderstaande figuren $3.9 \mathrm{t} / \mathrm{m} 3.16$ geven de resultaten voor het VBO, BOL niveau $1 \mathrm{t} / \mathrm{m} 4$ en $B B L$ niveau $1 \mathrm{t} / \mathrm{m} 4$. De cijfers geven de parameterschattingen weer voor de betreffende opleidingsniveaus waarbij het VBO als referentiecategorie dient. De betreffende cijfers geven derhalve de afwijking ten opzichte van het VBO weer en kunnen geïnterpreteerd worden als het effect van het volgen van respectievelijk 1, 2, 3 of 4 jaar additionele scholing in hetzij BOL hetzij BBL.

In de figuren is bovendien een trendlijn gegeven. Deze geeft - voor de betreffende indicator - de gemiddelde stijging per opleidingsniveau. Bij een continu model mag worden verwacht dat de vergelijking tussen de opleidingen een lineair verband oplevert omdat een toename van één niveau ook één jaar meer scholing betekent. Bij het opleidingsniveau is het (nominale) aantal jaren scholing vanaf 6-jarige leeftijd weergegeven voor schoolverlaters van het VBO (10 jaar) tot en met niveau 4 (14 jaar).

Tevens is in de figuren vermeld of de verschillen tussen de opeenvolgende opleidingsniveaus significant zijn. Op deze manier kan worden aangegeven of een toename van één niveau (d.w.z. één jaar additionele scholing) voor schoolverlaters significant meer oplevert op de arbeidsmarkt. 
Figuur 3.9a

Kans op deelname (voltijd/duaal) vervolgonderwijs voor schoolverlaters van de BOL (gecontroleerd)

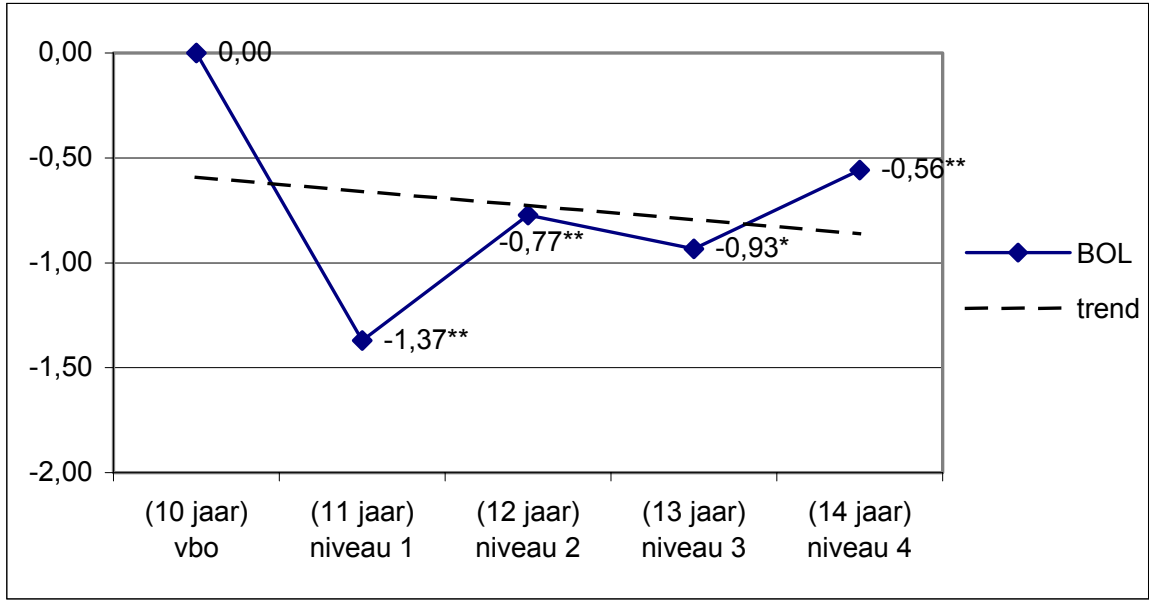

** = significant op $1 \%$-niveau

* = significant op 5\%-niveau

Figuur $3.9 b$

Kans op deelname aan (voltijd/duaal) vervolgonderwijs voor schoolverlaters van de BBL (gecontroleerd)

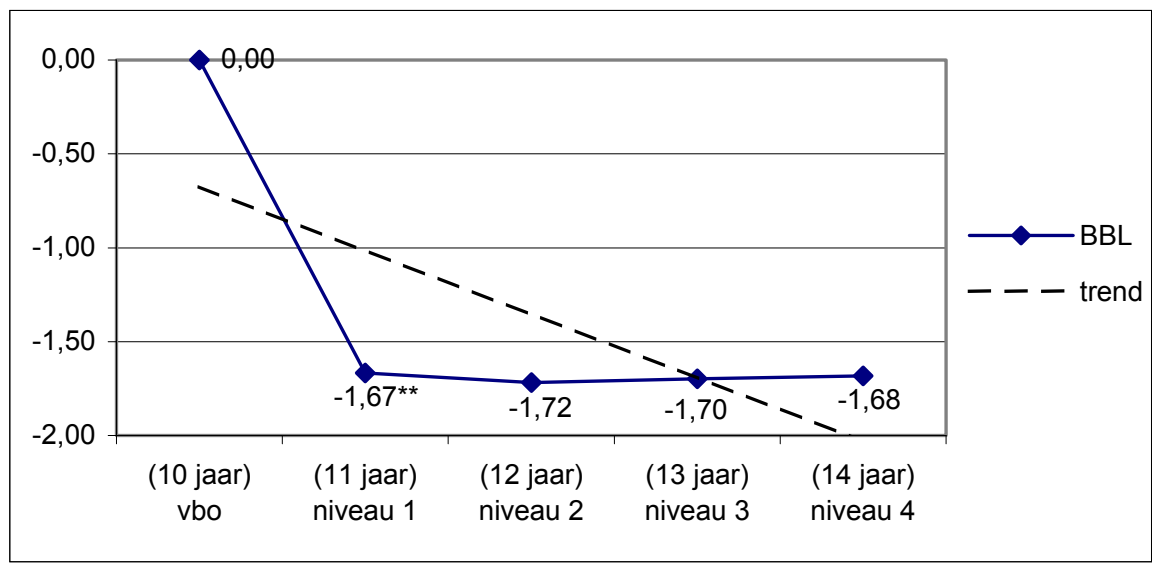

${ }^{* *}=$ significant op $1 \%$-niveau

* = significant op 5\%-niveau

Figuur 3.9a en figuur 3.9b gaan in op de doorstroom naar het vervolgonderwijs. $\mathrm{Na}$ controle voor individuele kenmerken blijkt dat schoolverlaters van het VBO significant vaker doorstromen naar een vervolgopleiding dan schoolverlaters van BOL niveau 1. Verder geldt voor de BOL dat de kans om verder te gaan leren voor schoolverlaters van niveau 1 zelfs kleiner is dan voor schoolverlaters van niveau 2. Figuur 3.9b laat zien dat schoolverlaters BBL niveau 1 beduidend minder vaak dan schoolverlaters van het VBO kiezen voor een vervolgopleiding, terwijl binnen de BBL vrijwel geen onderscheid bestaat tussen schoolverlaters van de verschillende opleidingsniveaus 
in de deelname aan vervolgonderwijs. De opleidingen BBL niveau 1 tot en met 4 verschillen ongeveer in gelijke mate van het VBO in de doorstroom van schoolverlaters naar het vervolgonderwijs.

Figuur 3.10a

Kans op uitval in het vervolgonderwijs voor verder studerende schoolverlaters van de BOL (gecontroleerd)

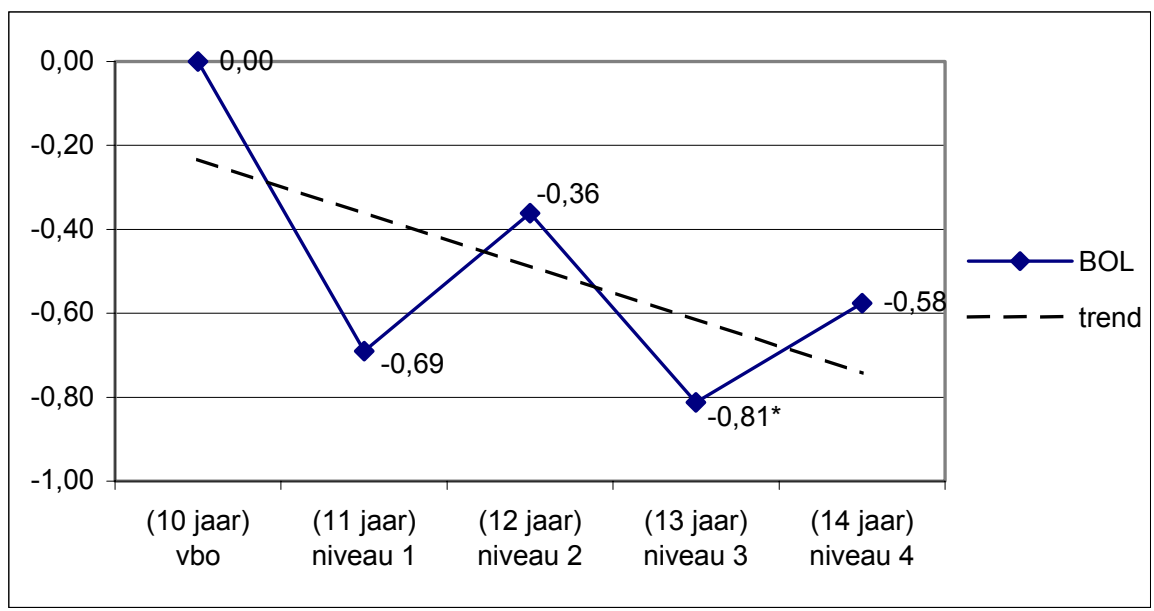

** = significant op $1 \%$-niveau

* $=$ significant op 5\%-niveau

Figuur 3.10b

Kans op uitval in het vervolgonderwijs voor verder studerende schoolverlaters van de BBL (gecontroleerd)

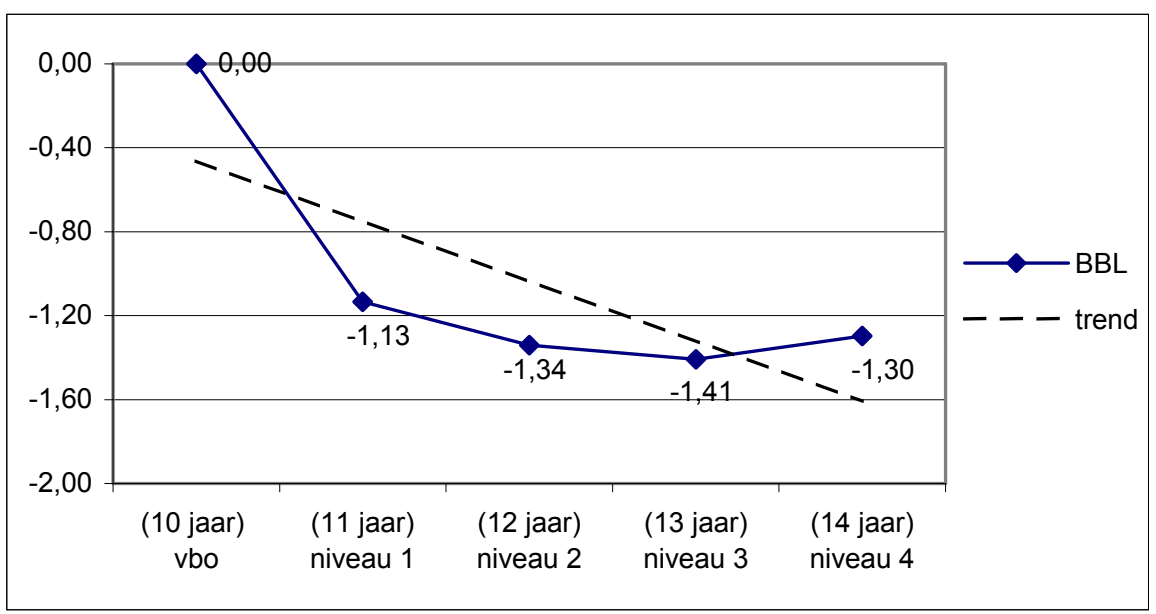

** $=$ significant op $1 \%$-niveau

* $=$ significant op $5 \%$-niveau

hoek $=-0,291(-0,287)$

In de figuren $3.10 \mathrm{a}$ en $3.10 \mathrm{~b}$ is de kans vermeld dat verder lerende schoolverlaters van de $\mathrm{BOL}$ en de BBL de vervolgopleiding voortijdig verlaten (uitval). Overigens zegt de kans op uitval in het vervolgonderwijs weinig over de waarde van een 
opleiding voor schoolverlaters op de arbeidsmarkt. Bij de uiteindelijke beoordeling van de waarde van de opleiding voor schoolverlaters zal daarom met deze indicator geen rekening gehouden. Na controle op achtergrondkenmerken van schoolverlaters blijkt dat de kans op uitval het grootst is onder verder lerende schoolverlaters van het VBO. Overigens is het verschil in de kans op uitval tussen verder lerende schoolverlaters van het VBO en opleidingen van niveau 1 niet significant. Opvallend is echter dat binnen de BOL de uitval onder verder lerende schoolverlaters het hoogst is bij niveau 2. Het verschil tussen niveau 2 en niveau 3 is hier significant. Dit kan een indicatie zijn dat voor schoolverlaters van BOL niveau 2 de opleiding minder goed aansluit op een vervolgopleiding dan voor schoolverlaters van BOL niveau 3 . Figuur 3.10b laat zien dat binnen de BBL de kans om de vervolgopleiding voortijdig te verlaten niet veel verschilt tussen de diverse opleidingsniveaus.

In figuur 3.11a en figuur 3.11b is de kans op werk weergegeven. Figuur 3.11a laat tussen schoolverlaters van het VBO en BOL niveau 1 de grootste toename zien in de kans op werk. Dit betekent dat voor schoolverlaters van VBO één jaar meer scholing een behoorlijke verbetering oplevert in de kans op werk. In vergelijking met het VBO biedt BOL niveau 1 schoolverlaters wat betreft de kans op werk al een veel betere start op de arbeidsmarkt. $\mathrm{Er}$ is slechts een lichte toename in de kans op werk tussen de schoolverlaters van $\mathrm{BOL}$ niveau 1 en schoolverlaters van $\mathrm{BOL}$ niveau 2, maar wel weer een grotere toename tussen schoolverlaters van BOL niveau 2 en BOL niveau 3. Overigens blijkt uit figuur 3.11a dat de verschillen in de kans op werk tussen de opeenvolgende opleidingsniveaus niet significant zijn.

Figuur 3.11a

Kans op werk voor schoolverlaters van de BOL (gecontroleerd)

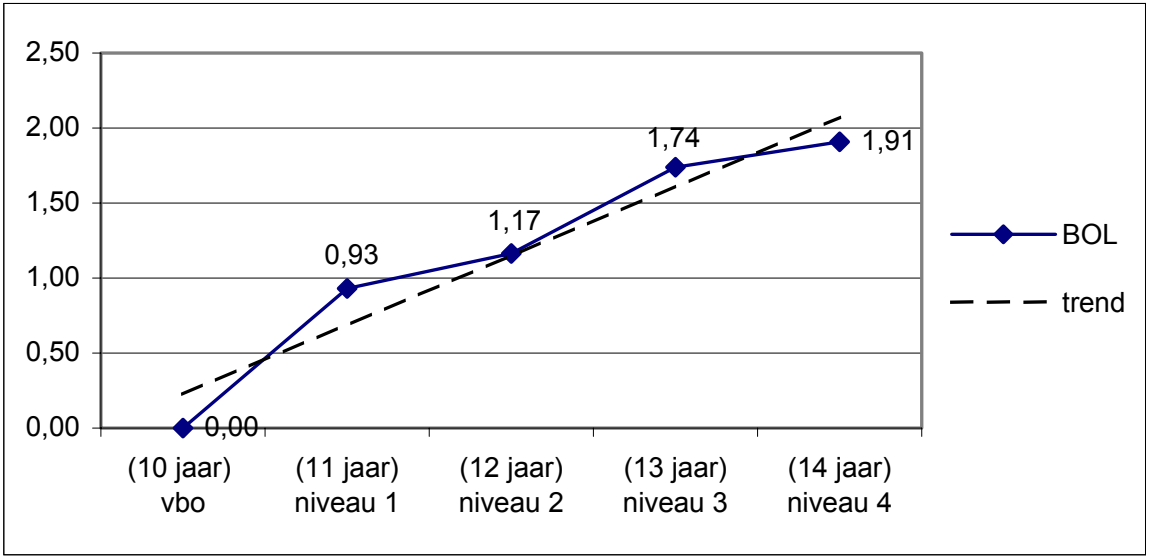

** = significant op $1 \%$-niveau

* = significant op 5\%-niveau

Figuur 3.11b laat zien dat de toename in de kans op werk bij de BBL opleidingen zich met name voordoet bij de overgang van BBL niveau 1 naar niveau 2. Daarnaast blijkt dat de kans op werk voor schoolverlaters van BBL niveau 2 en BBL niveau 3 maar weinig van elkaar verschilt. Ook hier geldt echter dat er geen significante verschillen bestaan in de kans op werk tussen de opeenvolgende opleidingsniveaus. Waar- 
schijnlijk heeft dit te maken met de krapte op de arbeidsmarkt waardoor het overgrote deel van de schoolverlaters betaald werk heeft gevonden anderhalf jaar na behalen van het diploma.

Figuur 3.11b

Kans op werk voor schoolverlaters van de BBL (gecontroleerd)

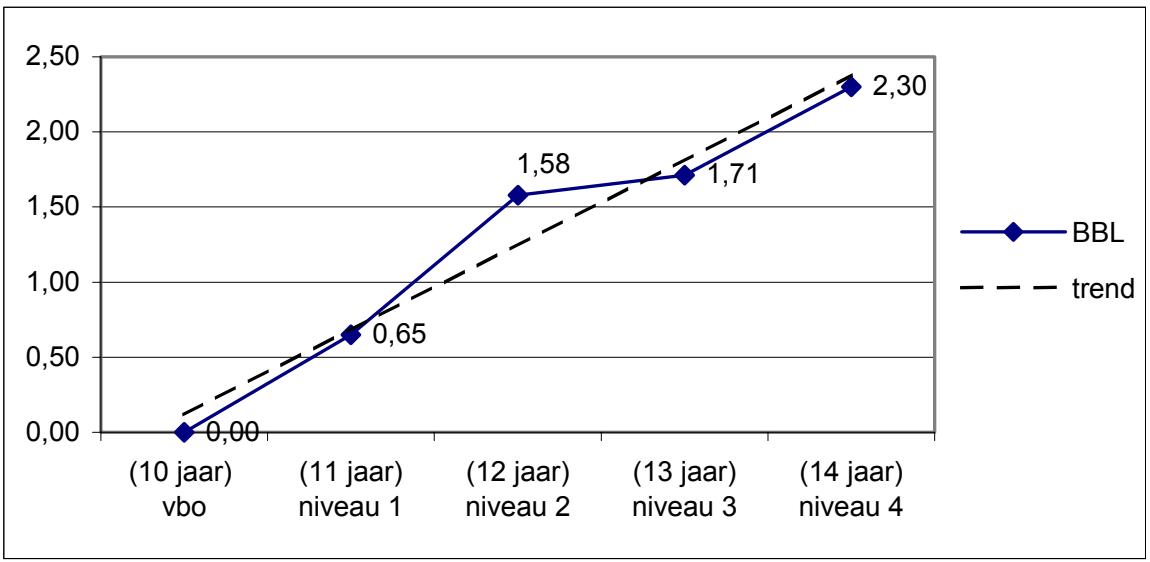

** = significant op $1 \%$-niveau

* = significant op $5 \%$-niveau

In figuur $3.12 \mathrm{a}$ en $3.12 \mathrm{~b}$ is de kans op een vaste aanstelling weergegeven. Bij de $\mathrm{BOL}$ (figuur 3.12a) bestaat een duidelijk onderscheid tussen niveau 1 en 2 enerzijds, en niveau 3 en 4 anderzijds. Daarbij is de kans op een vaste aanstelling voor schoolverlaters van niveau 3 en 4 groter dan voor schoolverlaters van niveau 1 en 2 . De figuur laat een significant verschil zien tussen schoolverlaters van niveau 2 en niveau 3 in de kans op een vaste aanstelling.

Figuur 3.12a

Kans op een vast dienstverband voor schoolverlaters van de BOL (gecontroleerd)

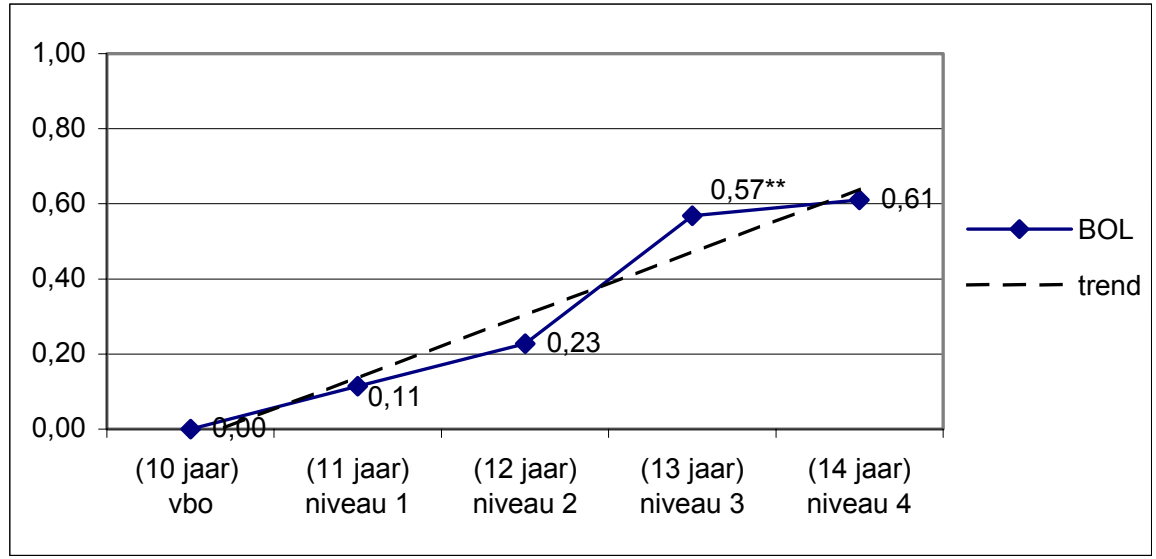

** = significant op $1 \%$-niveau

* $=$ significant op 5\%-niveau 
Figuur $3.12 b$

Kans op een vast dienstverband voor schoolverlaters van de BBL (gecontroleerd)

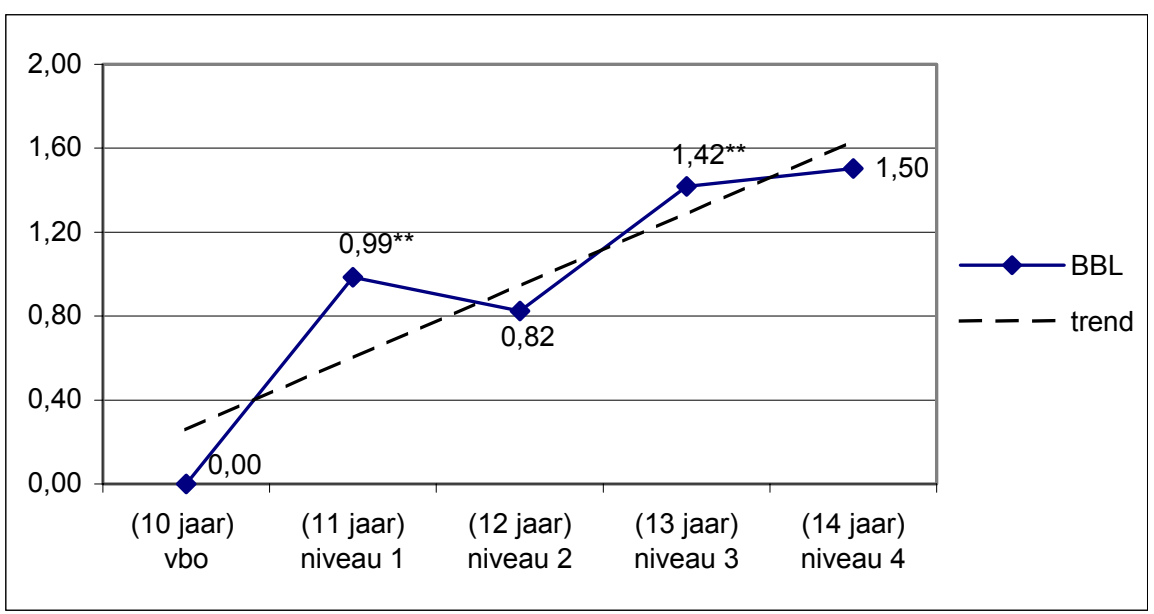

${ }^{* *}=$ significant op $1 \%$-niveau

* = significant op 5\%-niveau

Ook voor de BBL (figuur 3.12b) geldt dat schoolverlaters van niveau 2 meer lijken op schoolverlaters van niveau 1 dan op schoolverlaters van niveau 3 wat betreft de kans op een vaste aanstelling. De grote sprong doet zich hier echter voor bij de overgang van VBO naar BBL niveau 1. Eén jaar extra scholing geeft de schoolverlaters van het VBO een significante verbetering in de kans op een vaste aanstelling. De figuur laat zien dat er ook sprake is van een significante verbetering bij de overgang van BBL niveau 2 naar BBL niveau 3.

De figuren 3.13a en 3.13b laten zien dat voor schoolverlaters van de BOL en de BBL de kans op een voltijdbaan toeneemt met het opleidingsniveau. Schoolverlaters van niveau 1 hebben weliswaar minder vaak een voltijdbaan dan schoolverlaters van het VBO, maar vanaf niveau 1 neemt zowel bij de BOL als de BBL de kans op een voltijdbaan per opleidingsniveau geleidelijk toe. De relatief hoge percentages voltijd banen bij VBO schoolverlaters worden veroorzaakt door de selectie die is toegepast: degenen die na een VBO opleiding een BBL opleiding zijn gaan volgen zijn bij de bepaling van de waarde van de VBO opleiding buiten beschouwing gelaten. Bij de $\mathrm{BBL}$ is het verband vrijwel lineair. Per opleidingsniveau neemt de kans op een voltijdbaan in ongeveer gelijke mate toe. Voor de BOL geldt dit in iets mindere mate: de stijging van BOL niveau 2 naar BOL niveau 3 is groter dan de stijging van BOL niveau 1 naar BOL niveau 2. Het is overigens de vraag of we veel betekenis aan deze indicator moeten geven. De meeste schoolverlaters hebben een voltijdbaan, en degenen die geen voltijdbaan hebben doen dit bewust, bijvoorbeeld omdat ze werken en leren combineren in de BBL of omdat ze vanwege hun leeftijd geen voltijdbaan mogen hebben. Ook voor deze indicator geldt dat we deze niet mee zullen nemen in de uiteindelijke beoordeling van de waarde van de opleidingen. 
Figuur 3.13a

Kans op een voltijdbaan voor schoolverlaters van de BOL (gecontroleerd)

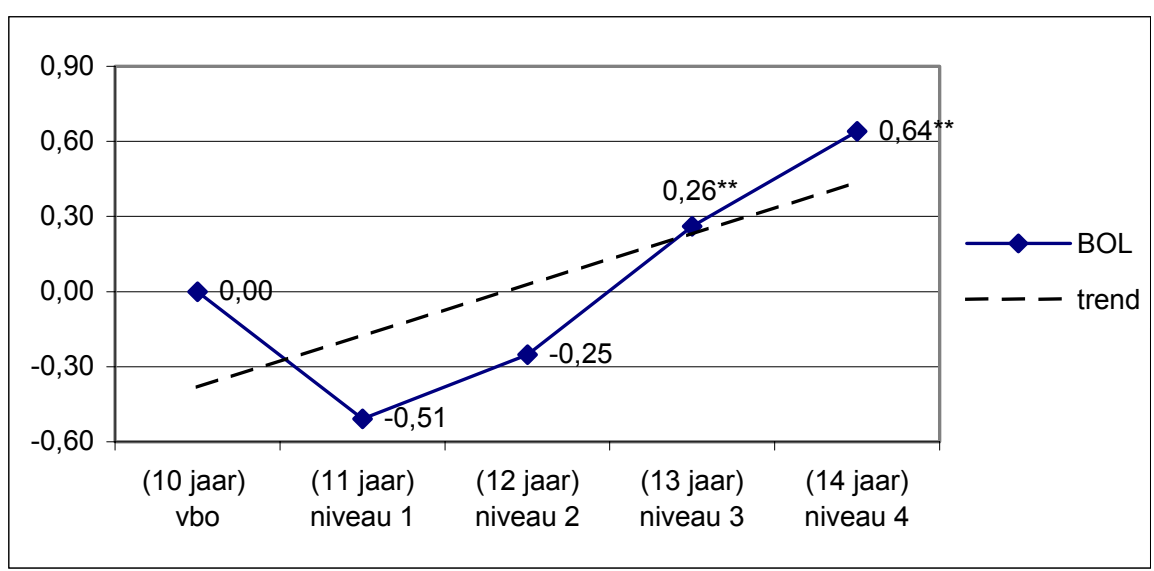

** = significant op $1 \%$-niveau

* = significant op 5\%-niveau

Figuur $3.13 b$

Kans op een voltijdbaan voor schoolverlaters van de BBL (gecontroleerd)

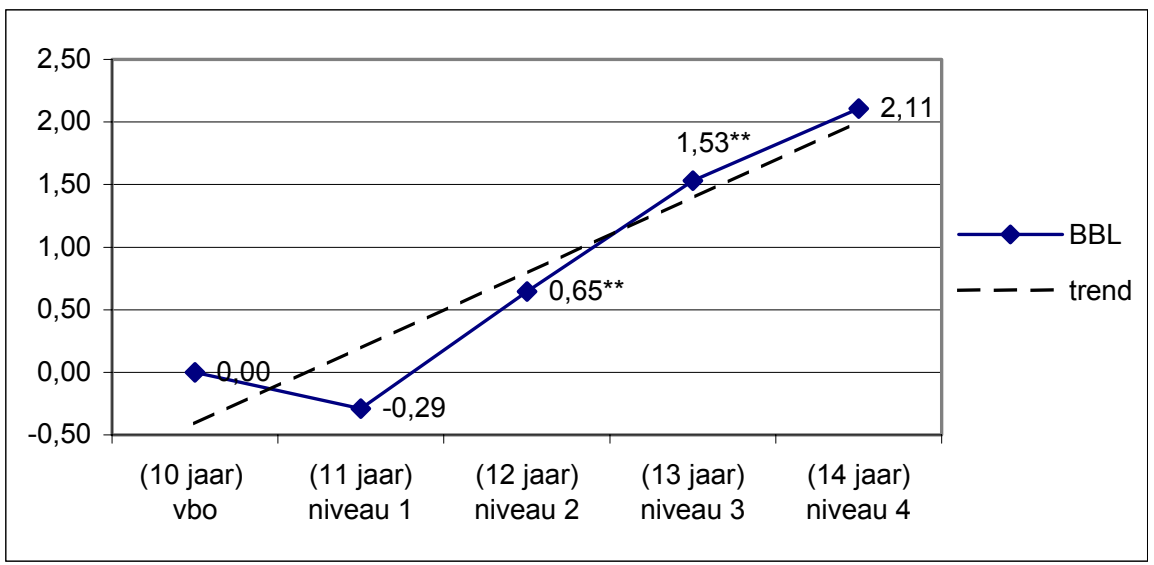

** = significant op $1 \%$-niveau

* = significant op $5 \%$-niveau

Figuur 3.14a en figuur 3.14b gaan in op het niveau van de baan van de schoolverlaters. Bij de BOL geldt dat schoolverlaters van niveau 2 zich duidelijk onderscheiden van schoolverlaters van niveau 1 wat betreft beroepsniveau. Figuur 3.14a laat zien dat de toename van het beroepsniveau het grootst is van BOL niveau 1 naar BOL niveau 2. Ook vanaf niveau 2 neemt het beroepsniveau van de baan van schoolverlaters significant toe met de toename van het opleidingsniveau, maar de sprongen zijn minder groot dan tussen niveau 1 en niveau 2.

Bij de BBL (figuur 3.14b) bestaat er geen verschil in het niveau van het beroep van schoolverlaters van BBL niveau 1 en BBL niveau 2. Voor schoolverlaters van BBL niveau 2 betekent dit dat de extra scholing geen baan oplevert van een hoger 
beroepsniveau ten opzichte van BBL niveau 1. Voor schoolverlaters van BBL niveau 3 geldt daarentegen dat ze zich in het niveau van het beroep duidelijk onderscheiden van schoolverlaters van BBL niveau 2. Figuur 3.14b laat een sterke (significante) toename zien in het beroepsniveau van de baan van BBL niveau 2 naar BBL niveau 3.

Figuur 3.14a

Niveau van het beroep voor schoolverlaters van de BOL (gecontroleerd)

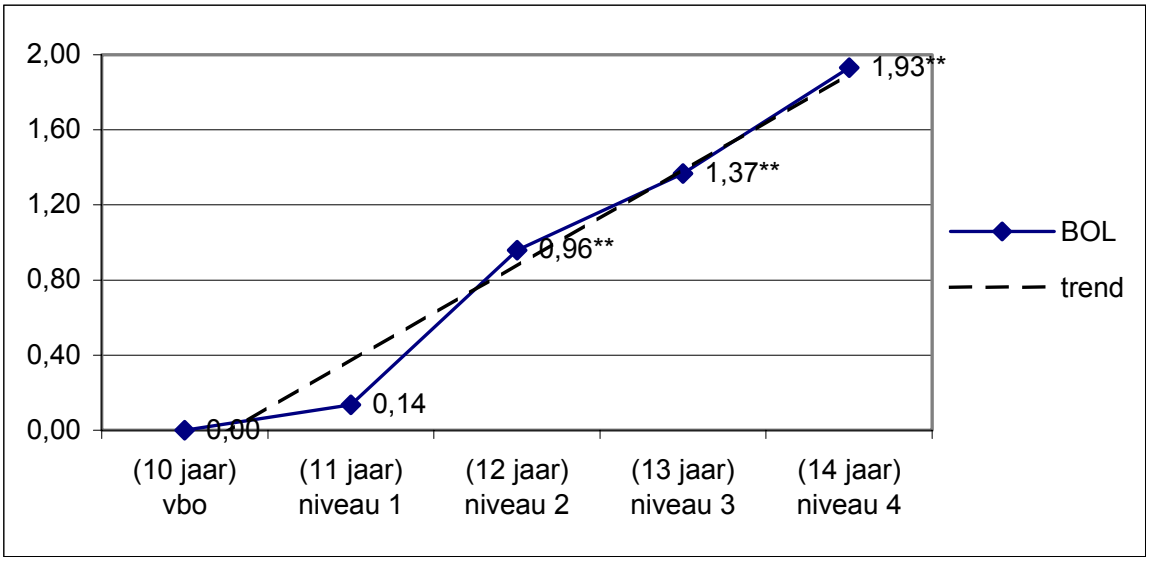

** = significant op $1 \%$-niveau

* $=$ significant op $5 \%$-niveau

Figuur $3.14 b$

Niveau van het beroep voor schoolverlaters van de BBL (gecontroleerd)

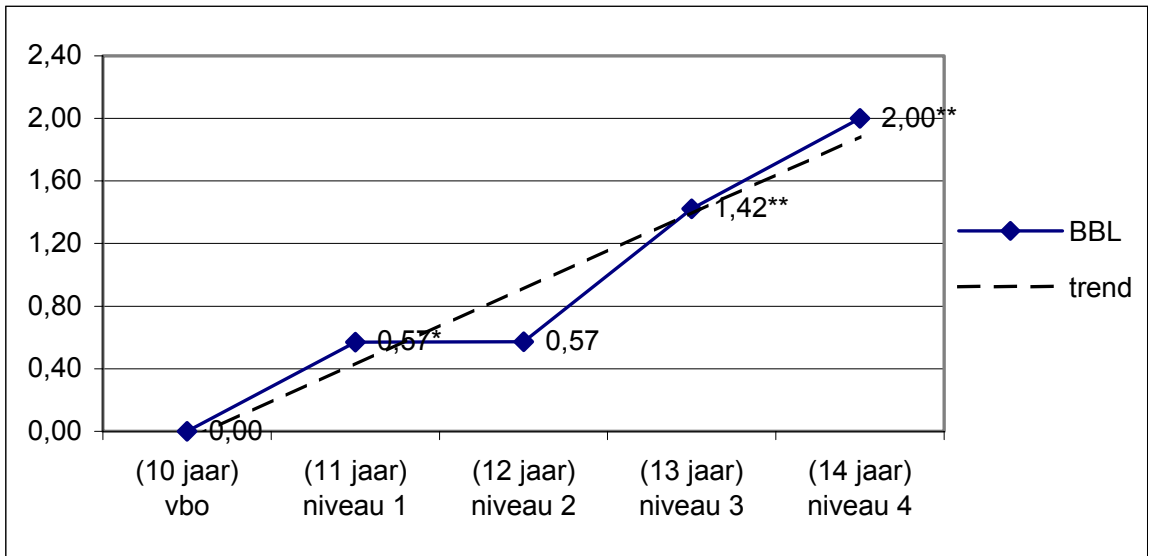

** = significant op $1 \%$-niveau

* $=$ significant op $5 \%$-niveau

In figuur 3.15a en figuur 3.15b zijn de resultaten vermeld met betrekking tot de kans op een baan die qua richting aansluit bij de gevolgde opleiding. Voor de BOL geldt dat opleidingen van BOL niveau 2 een betere kans geven op een baan die qua richting aansluit bij de gevolgde opleiding dan opleidingen op BOL niveau 1. Overigens is dit verschil niet significant. Daarnaast is voor schoolverlaters van BOL niveau 3 de kans op een baan die aansluit bij de gevolgde opleidingsrichting 
significant groter dan voor schoolverlaters van BOL niveau 2. Het verschil tussen niveau 2 en niveau 3 is echter exact gelijk aan het verschil tussen niveau 1 en niveau 2 , met de aantekening dat in het ene geval het verschil wel significant is en in het ander geval niet. Dit kan echter een gevolg zijn van het geringere aantal waarnemingen op niveau 1.

Figuur 3.15a

Kans op een baan in de eigen of verwante richting voor schoolverlaters van de BOL (gecontroleerd)

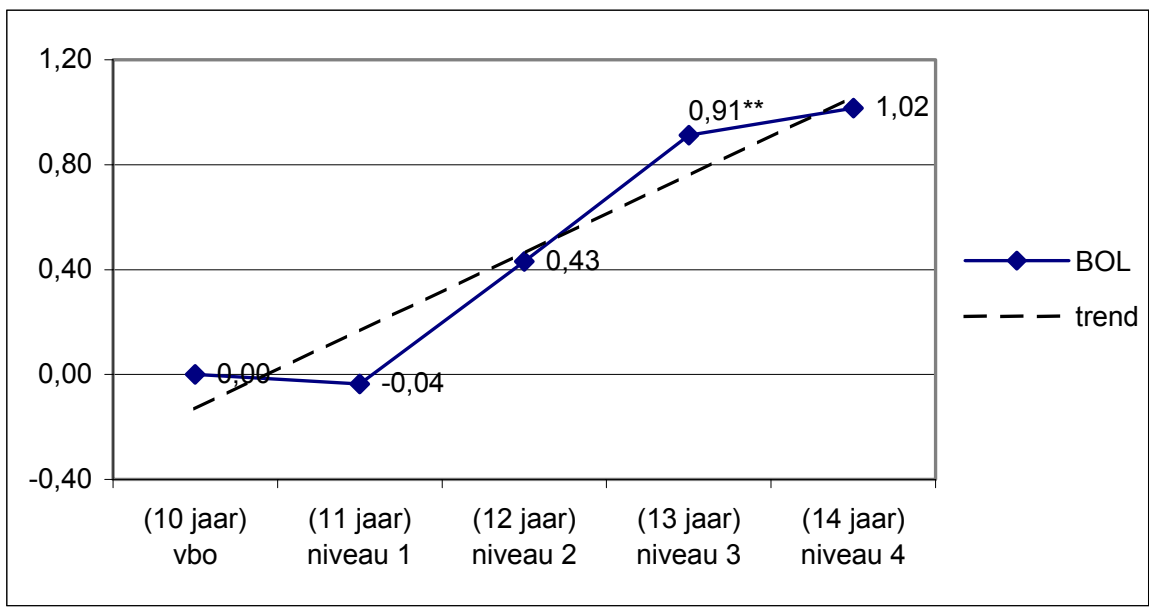

** = significant op $1 \%$-niveau

* = significant op 5\%-niveau

Figuur 3.15b

Kans op een baan in de eigen of verwante richting voor schoolverlaters van de BBL (gecontroleerd)

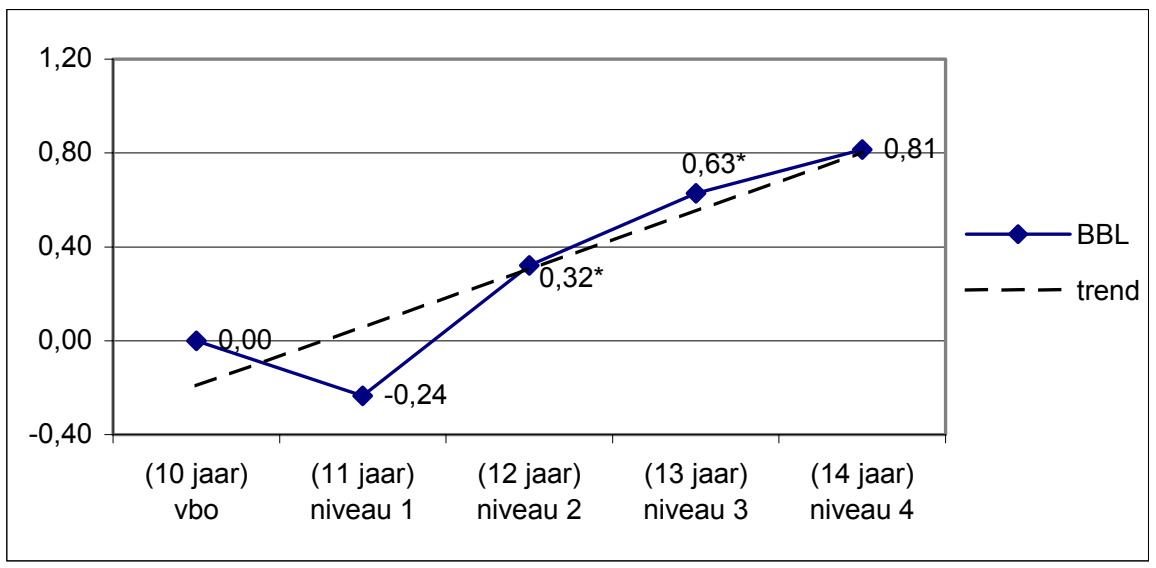

** = significant op $1 \%$-niveau

* $=$ significant op $5 \%$-niveau 
Binnen de BBL (figuur 3.15b) neemt de kans op een aansluitende baan naar richting ook toe met het niveau. Figuur 3.15b laat zien dat schoolverlaters van BBL niveau 2 een significant grotere kans hebben op een baan die aansluit bij de gevolgde opleidingsrichting dan schoolverlaters van BBL niveau 1. Tevens blijkt dat schoolverlaters van $B B L$ niveau 3 significant vaker een baan in de eigen richting hebben dan schoolverlaters van BBL niveau 2. De grootste sprong is hier echter van BBL niveau 1 naar BBL niveau 2.

Ten slotte is in figuur 3.16a en figuur 3.16b het bruto uurloon van de schoolverlaters weergegeven. Allereerst blijkt dat de grootste stijging van het bruto uurloon bij zowel de $B O L$ als de $B B L$ zich voordoet van het VBO naar niveau 1. Het extra jaar scholing ten opzichte van het VBO levert schoolverlaters van BOL niveau 1 een significante stijging op van het bruto uurloon (van 9\%). Vervolgens blijkt dat schoolverlaters van BOL niveau 2 niet significant meer verdienen dan schoolverlaters van BOL niveau 1. Boven niveau 2 stijgt het bruto uurloon wel weer significant met het opleidingsniveau. Schoolverlaters van BOL niveau 3 verdienen $6 \%$ meer dan schoolverlaters van $\mathrm{BOL}$ niveau 2 en de schoolverlaters van niveau 4 verdienen op hun beurt weer $8 \%$ meer dan de schoolverlaters van niveau 3.

Figuur 3.16a

Bruto uurloon voor schoolverlaters van de BOL (gecontroleerd)

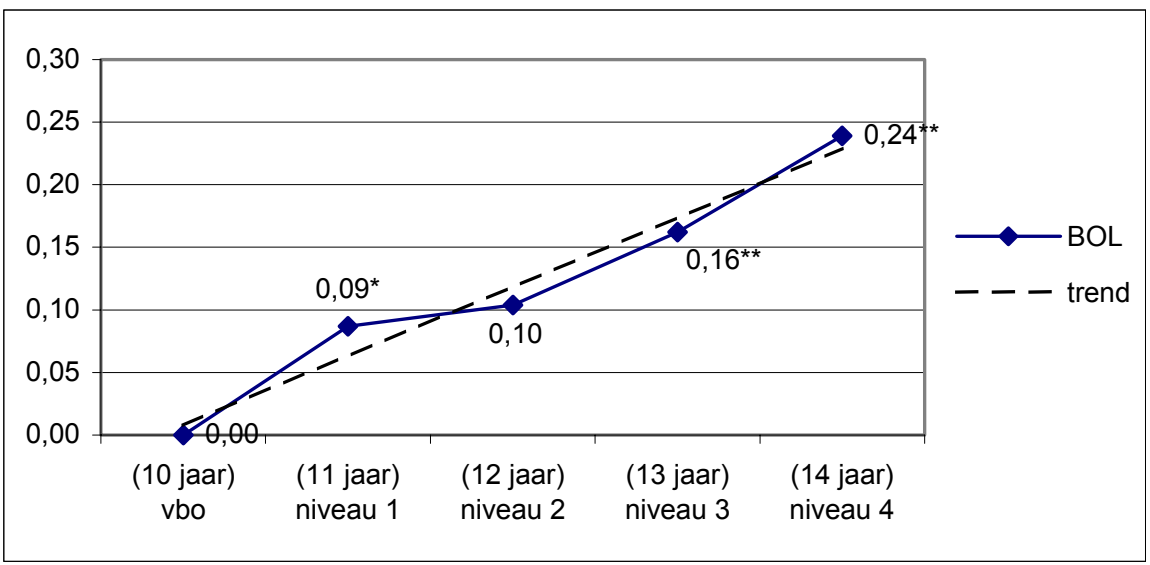

** = significant op $1 \%$-niveau

* = significant op 5\%-niveau

Voor schoolverlaters van BBL niveau 1 geldt dat een jaar extra scholing een flinke stijging oplevert van het bruto uurloon ten opzichte van schoolverlaters van het VBO (18\%). Vervolgens neemt bij de BBL het bruto uurloon per opleidingsniveau in vrijwel gelijke mate toe. Het bruto uurloon van schoolverlaters van BBL niveau 2 is $6 \%$ hoger dan voor schoolverlaters van BBL niveau 1, en ook het bruto uurloon van schoolverlaters van BBL niveau 3 is $6 \%$ hoger dan voor schoolverlaters van BBL niveau 2.

De geconstateerde discontinuïteiten sluiten een verklaring op basis van institutionele loonvorming uit. Het stelsel van minimum jeugdloon heeft immers tot gevolg dat de 
verschillen aan de onderkant kleiner worden in plaats van groter. De analyses wijzen echter uit dat de grootste discontinuïteiten zich bevinden aan de onderkant van het loongebouw tussen VBO en niveau 1.

Figuur 3.16b

Bruto uurloon voor schoolverlaters van de BBL (gecontroleerd)

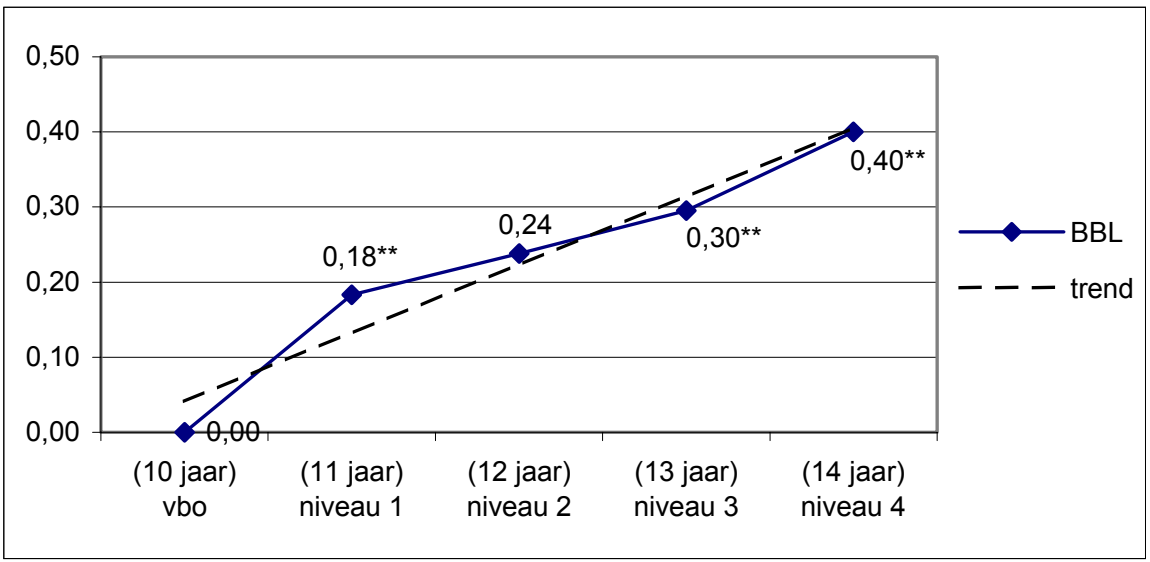

** = significant op $1 \%$-niveau

* $=$ significant op $5 \%$-niveau

\subsection{Conclusie}

Uit de analyse van de opbrengsten van opleidingen is naar voren gekomen dat in het algemeen de opbrengsten toenemen met het opleidingsniveau, maar dat die toename niet voor elk jaar additionele scholing gelijk is. In tabel 3.2 is een overzicht gegeven van de belangrijkste ${ }^{6}$ indicatoren die in dit hoofdstuk zijn geanalyseerd. In de tabel is aangegeven tussen welke opleidingsniveaus zich de grootste relatieve verbetering voor doet. Hiervoor zijn de figuren $3.9 \mathrm{t} / \mathrm{m} 3.16$ als uitgangspunt genomen.

Uit tabel 3.2 blijkt dat voor de BOL opleidingen de grens drie maal kan worden gelegd tussen het VBO en niveau 1 (kans op deelname aan vervolgonderwijs, kans op werk en bruto uurloon), één maal tussen niveau 1 en niveau 2 (niveau van het beroep) en twee maal tussen niveau 2 en niveau 3 (kans op een vaste aanstelling en kans op een baan in de eigen richting). Daarbij dient te worden aangetekend dat verschil tussen VBO en niveau 1 in het geval van de kans op werk niet significant is, en dat in het geval van de kans op een baan in de eigen richting het verschil tussen niveau 1 en niveau 2 even groot is als het verschil tussen niveau 2 en niveau 3 . Dat betekent dat vooral in het geval van de kans op een vast dienstverband schoolverlaters een aanmerkelijke verbetering in hun arbeidsmarktpositie realiseren wanneer ze een opleiding op niveau 3 in plaats van niveau 2 volgen. Voor de overige

6. De kans op uitval in het vervolgonderwijs en de kans op een voltijdbaan zijn hierbij weggelaten, vanwege het feit dat deze een minder geschikte indicator vormen voor de bepaling van de waarde van opleidingen. 
indicatoren lijkt een opleiding op niveau 2 reeds een sterke verbetering op te leveren en in 3 van de 5 gevallen ligt de grens zelfs bij een opleiding op niveau 1.

Wat betekent dit voor de startkwalificatie? Wanneer we als uitgangspunt hanteren dat de startkwalificatie op een zo groot mogelijk aantal indicatoren een substantiële verbetering van de opbrengsten moet genereren ten opzichte van de lagere opleidingsniveaus, dan kan men stellen dat niveau 2 van de BOL dit voor 5 van de 6 indicatoren realiseert en niveau 1 'slechts' voor 3 van de 6 indicatoren. Daarmee lijkt voor de BOL het gekozen niveau 2 als startkwalificatie redelijk adequaat te zijn, tenzij men zou stellen dat de startkwalificatie op alle indicatoren een verbetering moet realiseren. In dat laatste geval zou de startkwalificatie op niveau 3 gesitueerd moeten worden.

Tabel 3.2

Bepaling van de grens van opleidingen die een relatief goede start bieden op de arbeidsmarkt, voor zes indicatoren

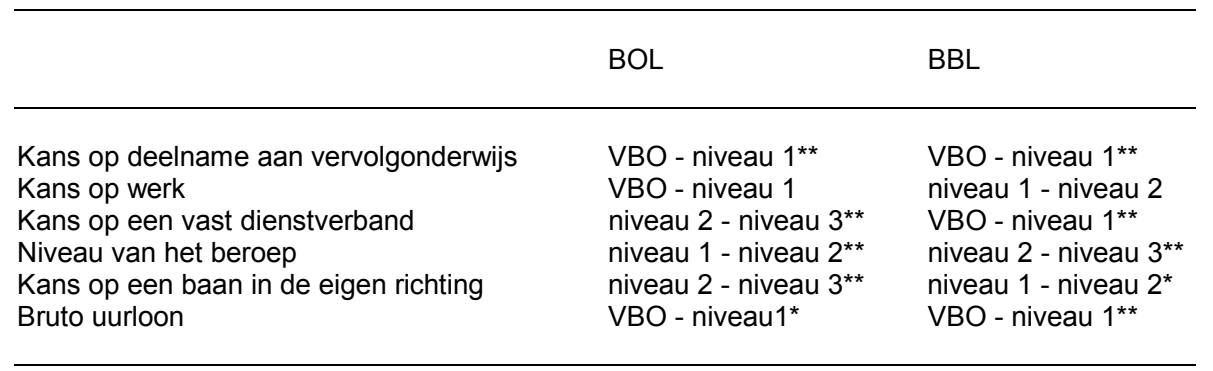

Voor de BBL geldt dat de belangrijkste sprongen zich ook driemaal voordoen bij de overgang van VBO naar niveau 1 (kans op deelname aan vervolgonderwijs, kans op een vaste aanstelling en bruto uurloon), twee maal bij de overgang van niveau 1 naar niveau 2 (kans op werk ${ }^{7}$ en kans op een baan in de eigen richting) en één maal bij de overgang van niveau 2 naar niveau 3 (niveau van het beroep). Daarmee hebben we in feite een vergelijkbare situatie als bij de BOL. Voor vijf van de zes indicatoren geldt dat opleidingen van BBL niveau 2 schoolverlaters relatief goede mogelijkheden bieden op de arbeidsmarkt. In het geval van de opleidingen op niveau 1 geldt dit slechts voor drie van de zes indicatoren. Ook hier kan geconcludeerd worden dat voor de opleidingen in BBL niveau 2 adequaat gekozen lijkt als startkwalificatie, tenzij men zou stellen dat een startkwalificatie op alle onderscheiden indicatoren een relatief sterke verbetering moet geven. Uitsluitend in dat laatste geval zou het niveau van startkwalificatie op niveau 3 gesitueerd moeten worden.

7. Wederom met de aantekening dat het verschil niet significant is. 


\section{De waarde van een startkwalificatie vanuit een internationaal perspectief}

\subsection{Inleiding}

In dit hoofdstuk wordt de waarde van de Nederlandse startkwalificatie vanuit een internationaal perspectief bestudeerd. Daartoe wordt op empirische wijze nagegaan in hoeverre het extern rendement van ISCED3C short opleidingen verschilt tussen Nederland en enkele andere Europese landen, waaronder Frankrijk en het Verenigd Koninkrijk. Een vergelijking met laatstgenoemde landen is vooral interessant, omdat opleidingen op het niveau van ISCED 3C short in deze twee landen - in tegenstelling tot Nederland - wel als level completion worden beschouwd door de OECD. De referentie voor de Nederlandse opleidingen op niveau ISCED 3C short zijn de buitenlandse opleidingen op niveau ISCED $3 C$ short, waarbij tevens een vergelijking plaatsvindt met andere opleidingen op niveau ISCED 3 (3A, 3B en 3C long) en met opleidingen op niveau ISCED 2. De volgende twee onderzoeksvragen zijn geformuleerd:

1. Wat is de waarde van de Nederlandse ISCED 3 C short opleidingen in termen van doorstroom naar vervolgonderwijs en kansen op de arbeidsmarkt in vergelijking met buitenlandse ISCED 3C short opleidingen?

2. Hoe verhoudt deze waarde zich tot die van andere opleidingen op niveau ISCED 3 (3A, 3B en $3 C$ long) enerzijds en opleidingen op niveau ISCED 2 anderzijds?

Voor wat betreft de toepassing van deze ISCED niveaus op de Nederlandse opleidingen wordt verwezen naar tabel 4.1. Hierin staat weergegeven hoe de opleidingen van het Nederlandse onderwijssysteem zijn ingedeeld in de ISCED 1997 (zie Bernelot Moens (2000) voor meer details).

Tabel 4.1

Toepassing ISCED 2-3 niveau op Nederlandse opleidingen

\begin{tabular}{|c|c|c|}
\hline ISCED 1997 niveau & Omschrijving & Nederlandse equivalent \\
\hline ISCED 2 & Lower secondary education & $\begin{array}{l}\text { HAVO (klas 1-3); VWO (klas 1- } \\
\text { 3); MAVO; VBO; BOL/BBL } \\
\text { niveau 1 }\end{array}$ \\
\hline ISCED 3C short & $\begin{array}{l}\text { Upper secondary education, not } \\
\text { designed to lead to tertiary education, } \\
<3 \text { years }\end{array}$ & BOL/BBL niveau 2 \\
\hline ISCED 3C long & $\begin{array}{l}\text { Upper secondary education, not } \\
\text { designed to lead to tertiary education, } \\
\geq 3 \text { years }\end{array}$ & BOL/BBL niveau 3 \\
\hline ISCED 3B & $\begin{array}{l}\text { Upper secondary education, designed } \\
\text { to give access to short, practically } \\
\text { oriented tertiary education }\end{array}$ & - \\
\hline ISCED 3A & $\begin{array}{l}\text { Upper secondary education, designed } \\
\text { to give access to tertiary education }\end{array}$ & $\begin{array}{l}\text { HAVO (klas 4-5); VWO (klas 4- } \\
\text { 6); BOL/BBL niveau } 4\end{array}$ \\
\hline
\end{tabular}

- : niet van toepassing 


\subsection{Onderzoeksopzet}

Voor het beantwoorden van bovengenoemde onderzoeksvragen wordt gebruik gemaakt van de European Union Labour Force Survey (EU LFS), verzameld in 2000. Dit gecombineerde gegevensbestand - beschikbaar gesteld door Eurostat - bevat data van een deel van de oorspronkelijke, nationale Labour Force Surveys (LFS) voor Nederland de Enquête Beroepsbevolking (EBB) - zoals die jaarlijks in de vijttien lidstaten van de Europese Unie worden gehouden. Voor de huidige analyse worden slechts gegevens gepresenteerd over Nederland (NL), Frankrijk (FR), het Verenigd Koninkrijk (UK), Griekenland (GR), Spanje (ES) en Italië (IT). De reden hiervoor is dat voor de overige lidstaten geen onderscheid bestaat dan wel wordt gemaakt op het niveau van ISCED $3 \mathrm{C}$ short opleidingen. In tabel 4.2 is per onderzocht land het aandeel van de bevolking in de leeftijd van 15-64 jaar met een opleiding op ISCED23 niveau weergegeven. Tevens is daarbij vermeld om hoeveel individuen het gaat. In Nederland, bijvoorbeeld, heeft 5,9\% van de 15-64 jarigen een diploma op het niveau van ISCED 3C short, wat overeenkomt met een aantal van 628.000 individuen.

Tabel 4.2

Het aandeel van de bevolking met een opleiding op ISCED2-3 niveau per land, 15-64 jarigen (percentages en absolute aantallen ( $\left.{ }^{*} 1.000\right)$ )

\begin{tabular}{lllllll}
\hline Opleidingsniveau & NL & FR & UK & GR & ES & IT \\
& & & & & & \\
\hline \multirow{2}{*}{ ISCED 2 } & $24,2 \%$ & $23,5 \%$ & $18,5 \%$ & $15,1 \%$ & $25,7 \%$ & $23,5 \%$ \\
& 2.566 & 8.847 & 6.110 & 1.036 & 6.597 & 8.847 \\
ISCED 3C short & $5,9 \%$ & $26,8 \%$ & $16,9 \%$ & $2,5 \%$ & $0,2 \%$ & $8,2 \%$ \\
ISCED 3C long & 628 & 10.105 & 5.586 & 170 & 47 & 3.099 \\
& $16,6 \%$ & - & $14,2 \%$ & $6,8 \%$ & $0,1 \%$ & $2,0 \%$ \\
ISCED 3B & 1.768 & & 4.698 & 466 & 28 & 756 \\
& - & $1,6 \%$ & - & $2,2 \%$ & $5,7 \%$ & $0,4 \%$ \\
ISCED 3A & $19,3 \%$ & $11,5 \%$ & $25,1 \%$ & $26,1 \%$ & $13,8 \%$ & $26,1 \%$ \\
& 2.055 & 4.337 & 8.317 & 1.790 & 3.551 & 9.826 \\
\end{tabular}

- : niet van toepassing

Bron: Eurostat, EU LFS 2000, eigen berekeningen

Om de waarde van een startkwalificatie tijdens de transitie van school naar werk adequaat vast te stellen, beperkt de analyse zich tot de leeftijdsgroep van 15-24 jarigen. De volgende aspecten van het extern rendement van opleidingen worden geanalyseerd:

- Deelname aan vervolgonderwijs;

- Deelname aan beroepsbevolking;

- Betaald werk;

- Vast werk;

- Voltijd werk;

- Beroepsprestige.

Bij de deelname aan vervolgonderwijs gaat het om onderwijsactiviteiten (zowel initiële opleidingen als aanvullende scholing) die in de vier weken voorafgaand aan 
het moment van ondervraging hebben plaatsgevonden. Daarmee geeft deze indicator aan voor wie het tot dan toe hoogst bereikte opleidingsniveau geen eindonderwijs is gebleken. De deelname aan de beroepsbevolking is bepaald aan de hand van een enigszins aangepaste ILO-definitie (ILO, 1990). Alle personen die op het moment van ondervraging strikt genomen tot de beroepsbevolking zouden behoren, maar tegelijkertijd deelnemen aan een initiële opleiding, zijn uitgesloten van de beroepsbevolking. De overige indicatoren hebben betrekking op de werkzame beroepsbevolking. Het gaat daarbij om individuen die ten minste één uur betaald werk hebben verricht in de week waarin zij werden ondervraagd en individuen die niet hebben gewerkt in die week, maar wel een betaalde baan hebben waarvan zij in de betreffende week verlof hadden. De duur van het dienstverband is gemeten door een onderscheid te maken tussen vast en tijdelijk werk. Vast werk verwijst naar een contract voor onbepaalde tijd. Verder is de tegenstelling tussen voltijd en deeltijd werk geanalyseerd. Dit onderscheid is gebaseerd op de inschatting van de ondervraagde en niet op het werkelijk aantal gewerkte uren per week. Tot slot is het bereikte beroepsprestige vastgesteld. Beroepen zijn ingedeeld volgens de ISCO-88 classificatie (ILO 1990). Het bereikte beroepsprestige is bepaald door gebruik te maken van de ISEI (Ganzeboom, De Graaf en Treiman 1992; Ganzeboom en Treiman 1996). Op basis van dit veelgebruikte meetinstrument voor sociale status worden scores toegewezen aan beroepstitels (op basis van driecijferige informatie uit de ISCO-88 classificatie) volgens een schaal die loopt van 16 voor beroepen met de laagste status tot 90 voor beroepen met de hoogste status.

De empirische analyse begint met een beschrijving van bovengenoemde aspecten van het extern rendement van opleidingen in de verschillende landen. Het gaat daarbij om absolute verschillen. Vervolgens worden verschillen in het extern rendement van opleidingen tussen landen vastgesteld waarbij rekening wordt gehouden met individuele kenmerken. Het is goed mogelijk dat de geconstateerde verschillen in de positie van opleidingen worden veroorzaakt door variatie tussen opleidingen in de samenstelling naar leeftijd en sekse. Om die reden zijn de verschillen tussen opleidingen opnieuw geanalyseerd, maar nu gecontroleerd voor leeftijd en sekse. De parameterschattingen geven logodds ratio's weer voor de betreffende opleidingsniveaus, waarbij het niveau van ISCED $3 \mathrm{C}$ short telkens als referentiecategorie dient. De betreffende cijfers geven de afwijking ten opzichte van dit opleidingsniveau weer en kunnen worden geïnterpreteerd als relatieve kansen. Een logodds ratio groter dan 0 voor een bepaald opleidingsniveau duidt op de grotere kans dan die voor de referentiecategorie (dat wil zeggen ISCED 3C short), een logodds ratio kleiner dan 0 slaat op een kleinere kans en een logodds ratio van precies 0 impliceert dat de kans voor een bepaald opleidingsniveau gelijk is aan die van de referentiecategorie. Alleen bij de analyse van het bereikte beroepsprestige geven de parameterschattingen geen logodds ratio's weer, maar ongestandaardiseerde regressie-coëfficiënten. Deze kunnen worden geïnterpreteerd als geschatte verschillen in het bereikte beroepsprestige tussen opleidingen.

Om de gevonden verschillen op hun statistische significantie te beoordelen, zijn de aantallen respondenten per land gelijkgesteld en teruggewogen naar 5.000 respondenten per land. Hierdoor vindt bij het toetsen van de statistische significantie 
geen vertekening plaats als gevolg van ongelijke steekproefgrootte tussen de verschillende landen.

\subsection{Resultaten}

\subsubsection{Deelname aan vervolgonderwijs}

In figuur 4.1 is te zien dat er aanzienlijke verschillen zijn tussen opleidingsniveaus in de doorstroom naar vervolgonderwijs. Een groot deel van de 15-24 jarigen met een diploma op het niveau van ISCED 2 stroomt door naar een vervolgopleiding. Dit betreft vooral een opleiding in het secundair beroepsonderwijs. Er zijn wel enkele verschillen tussen landen te constateren. In Frankrijk, Griekenland en Nederland is voor ongeveer $80 \%$ van de jongeren ISCED 2 niveau geen eindonderwijs, terwijl het overeenkomstige percentage voor het Verenigd Koninkrijk en Italië rond de $60 \%$ ligt. In Spanje stroomt minder dan de helft van de jongeren met een diploma op het niveau van ISCED 2 door naar een vervolgopleiding. Deelname aan vervolgonderwijs onder jongeren met een ISCED 3 C short opleiding ligt een heel stuk lager. In Nederland, Frankrijk en het Verenigd Koninkrijk bedraagt de participatiegraad ongeveer $40 \%$. In de onderscheiden Zuid-Europese landen is dit aandeel nog een stuk lager, waarbij Griekenland verreweg het laagste cijfer laat zien (8\%). Deelname aan vervolgonderwijs onder jongeren met een ISCED 3 C long opleiding ligt in alle onderscheiden landen beduidend hoger. Een uitzondering wordt gevormd door Nederland, waar het percentage jongeren dat doorstroomt naar een vervolgopleiding iets lager is bij ISCED 3C long dan bij ISCED 3C short opleidingen. Het verschil is echter niet groot $(40 \%-37 \%=3 \%)$. Ook de deelname aan vervolgonderwijs onder jongeren met ISCED 3B is een stuk hoger dan bij ISCED 3C short. In Griekenland en Italië is de deelname aan vervolgonderwijs bij jongeren met een ISCED 3B opleiding zelfs hoger dan bij hen met ISCED $3 \mathrm{C}$ long. De deelname aan vervolgonderwijs onder jongeren met ISCED 3A ligt in alle landen ongeveer op hetzelfde hoge peil als onder degenen met een opleiding op het niveau van ISCED 2. Het gaat hier echter om doorstroom naar het hoger onderwijs.

In tabel 4.3 zijn bovengenoemde bevindingen nader geanalyseerd met behulp van multivariate analyse. De resultaten bevestigen de eerder gevonden verschillen in de kans op deelname aan vervolgonderwijs tussen opleidingsniveaus en landen. In alle landen - met uitzondering van Spanje - is de relatieve kans op doorstroom naar vervolgonderwijs voor 15-24 jarigen met een opleiding op het niveau van ISCED 2 significant hoger dan voor hen met een ISCED 3C short opleiding. Dat geen significant effect wordt gevonden voor Spanje, hangt vooral samen met het kleine aantal individuen in dit land dat een opleiding op het niveau van ISCED 3C short heeft (de referentiecategorie). De geschatte logodds ratio bedraagt voor Nederland 0,70 . Voor Griekenland, Italië en Frankrijk is de overeenkomstige logodds ratio significant groter, hetgeen impliceert dat de relatieve kans op doorstroom naar vervolgonderwijs voor degenen met een ISCED 2 opleiding in deze landen groter is dan in Nederland. Ten aanzien van ISCED $3 \mathrm{C}$ long geldt dat in het Verenigd Koninkrijk en Italië de doorstroom naar vervolgonderwijs onder jongeren met dit opleidingsniveau hoger is dan onder hen met een opleiding op het niveau van ISCED 
3C short. Daarmee geldt tevens dat voor beide landen de geschatte logodds ratio significant groter is dan voor Nederland. Ook wat betreft opleidingen op het niveau van ISCED 3B zijn enkele significante verschillen aanwezig. In Italië, Griekenland en Frankrijk is de deelname aan vervolgonderwijs onder jongeren met een diploma op dit opleidingsniveau hoger dan onder hen met een kwalificatie op het niveau van ISCED 3C short. Verder laten de bevindingen met betrekking tot ISCED 3A zien dat de deelname aan vervolgonderwijs onder degenen met dit opleidingsniveau significant hoger is dan onder hen met een opleiding op het niveau van ISCED 3C short. Dit is het geval in alle onderscheiden landen. Het is echter wel zo dat de geschatte logodds ratio voor Griekenland, Spanje, Italië en Frankrijk significant groter is dan de overeenkomstige schatting voor Nederland.

\section{Figuur 4.1}

Kans op deelname aan vervolgonderwijs, 15-24 jarigen (percentages)

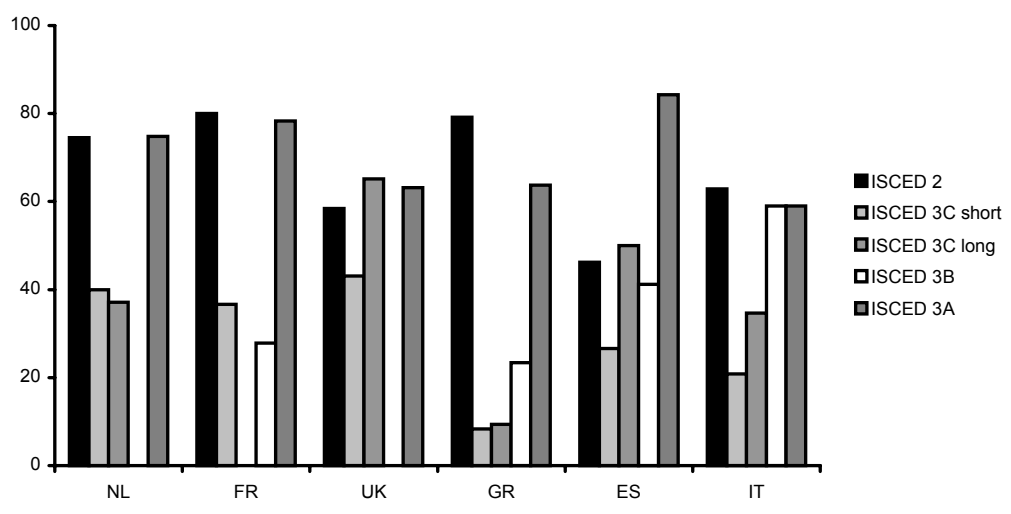

Bron: Eurostat, EU LFS 2000, eigen berekeningen

Tabel 4.3

Relatieve kans op deelname aan vervolgonderwijs, 15-24 jarigen (logodds ratio's) ${ }^{a}$

\begin{tabular}{|c|c|c|c|c|c|c|}
\hline Opleidingsniveau & $\mathrm{NL}$ & FR & UK & GR & ES & IT \\
\hline ISCED 2 & $0,70^{* *}$ & $0,76^{\star \star \# \#}$ & $0,41^{* *}$ & $2,93^{\star \star \star \# \# ~}$ & 0,46 & $1,16^{\star \star \# \#}$ \\
\hline ISCED $3 C$ short & 0,00 & 0,00 & 0,00 & 0,00 & 0,00 & 0,00 \\
\hline ISCED 3C long & 0,05 & - & $0,85^{\star \star \# \#}$ & 0,87 & 1,68 & $1,68^{* \star \# \#}$ \\
\hline ISCED 3B & - & $0,39^{*}$ & - & $1,55^{\star *}$ & 0,98 & $2,62^{* *}$ \\
\hline ISCED 3A & $1,52^{* *}$ & $2,36^{\star \star \# \#}$ & $1,48^{* *}$ & $3,55^{\star \star \# \#}$ & $3,25^{\star \star \# \#}$ & $2,63^{\star \star \# \#}$ \\
\hline
\end{tabular}

a : statistisch gecontroleerd voor leeftijd en sekse

* : $p<0,05$

**: $p<0,01$ (test van verschillen ten opzichte van ISCED 3 C short; per land)

\# : $p<0,01$ (test van verschillen ten opzichte van Nederland; per opleidingsniveau)

- : niet van toepassing

Bron: Eurostat, EU LFS 2000, eigen berekeningen 


\subsubsection{Deelname aan beroepsbevolking}

Figuur 4.2 toont in hoeverre de deelname aan de beroepsbevolking onder jongeren verschilt tussen opleidingsniveaus en landen. Min of meer vormt deze indicator het spiegelbeeld van de deelname aan vervolgonderwijs. Uit figuur $4.2 \mathrm{komt}$ dan ook naar voren dat de participatiegraad verreweg het laagst is onder degenen met alleen ISCED 2 niveau. Er bestaat echter wel aanzienlijk wat variatie tussen landen. De deelname aan de beroepsbevolking is het laagst in Frankrijk en Griekenland, waar deze $17 \%$ bedraagt. Het hoogst is de deelname in Spanje met een aandeel van $52 \%$. De arbeidsmarktparticipatie van personen met een opleiding op het niveau van ISCED 3C short ligt een aanzienlijk stuk hoger. In Griekenland is dit percentage het hoogst (88\%); in Frankrijk het laagst (62\%). De deelname aan het arbeidsproces van individuen met ISCED 3 C long ontloopt nauwelijks dat van hen met ISCED 3C short. In Nederland en Griekenland is het eerstgenoemde aandeel iets hoger; in Spanje, Italië en het Verenigd Koninkrijk ligt het lager. De arbeidsmarktparticipatie van degenen met een ISCED 3B opleiding ligt een stuk lager dan die van hen met een opleiding op het niveau van ISCED 3C short. Een uitzondering vormt Frankrijk, waar het percentage voor hen met ISCED 3B 11\% hoger ligt (73\% - 62\%). De arbeidsmarktdeelname van individuen met ISCED $3 \mathrm{~A}$ is in bijna alle landen een heel stuk lager dan die van individuen met ISCED 3C (short en long) en ISCED 3B. Alleen in het Verenigd Koninkrijk heeft de arbeidsmarktparticipatie min of meer een vergelijkbaar niveau.

Figuur 4.2

Kans op deelname aan beroepsbevolking, 15-24 jarigen (percentages)

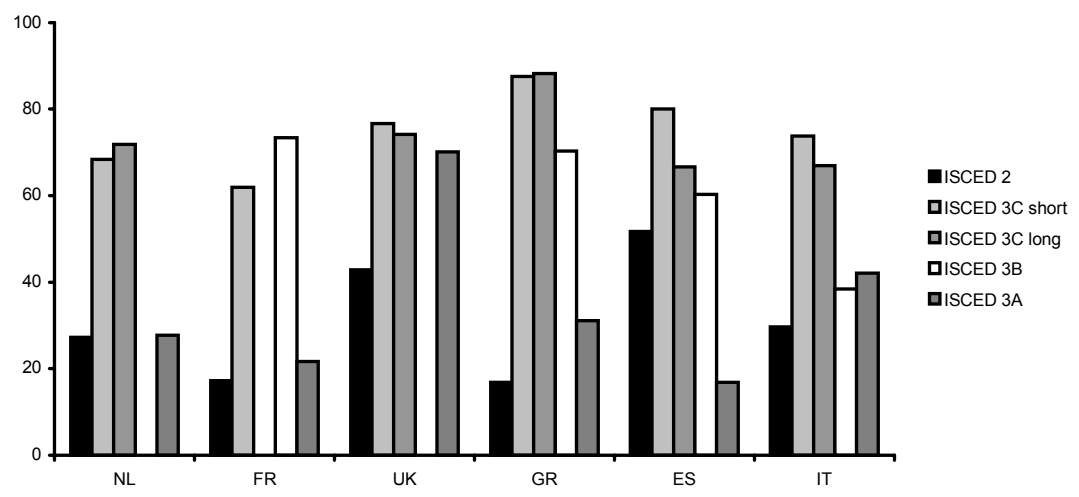

Bron: Eurostat, EU LFS 2000, eigen berekeningen

In tabel 4.4 zijn bovenstaande bevindingen wederom getoetst met behulp van multivariate analyse. Zoals eigenlijk al te verwachten viel op basis van figuur 4.2 is de deelname aan de beroepsbevolking onder degenen met een opleiding op het niveau van ISCED 2 significant lager dan onder hen met een ISCED 3C short opleiding. Opnieuw is het effect niet significant voor Spanje. Daarnaast blijkt uit tabel 4.4 dat de relatief geringere arbeidsmarktdeelname van degenen met ISCED 2 in Griekenland significant lager is dan in Nederland. Uit tabel 4.4 komt verder naar 
voren dat in Italië de relatieve kans op deelname aan de beroepsbevolking significant lager is onder degenen met een diploma op het niveau van ISCED 3C long dan onder hen met ISCED $3 C$ short. De betreffende logodds ratio bedraagt $-0,94$. Ook is in Italië - evenals in Spanje - de relatieve kans op deelname aan de beroepsbevolking significant lager onder degenen met een diploma op het niveau van ISCED 3B. Voor wat betreft ISCED 3A ten slotte geldt dat de arbeidsmarktparticipatie van jongeren met dit opleidingsniveau in de meeste onderzochte landen significant lager is dan de deelname van hen met een opleiding op het niveau van ISCED 3C short. In het Verenigd Koninkrijk is het effect niet significant, hoewel de logodds ratio in de verwachte richting wijst. De geschatte logodds ratio voor dit land wijkt dan ook significant af van de overeenkomstige logodds ratio voor Nederland. Dit is eveneens het geval voor Spanje, maar hier is de logodds ratio significant groter dan die voor Nederland.

Tabel 4.4

Relatieve kans op deelname aan beroepsbevolking, 15-24 jarigen (logodds ratio's) ${ }^{a}$

\begin{tabular}{lclllll}
\hline Opleidingsniveau & NL & FR & UK & GR & ES & IT \\
\hline & & & & & \\
ISCED 2 & $-1,04^{* *}$ & $-1,00^{* *}$ & $-1,41^{* *}$ & $-2,51^{* *}$ & $-1,10$ & $-1,29^{* *}$ \\
ISCED 3C short & 0,00 & 0,00 & 0,00 & 0,00 & 0,00 & 0,00 \\
ISCED 3C long & $-0,03$ & - & $-0,04$ & $-0,33$ & $-1,49$ & $-0,94^{* *}$ \\
ISCED 3B & - & $-0,17$ & - & $-1,25$ & $-1,47^{*}$ & $-2,02^{* *}$ \\
ISCED 3A & $-1,76^{* *}$ & $-2,17^{* *}$ & $-0,48^{\# \#}$ & $-3,01^{* *}$ & $-3,73^{* *}$ & $-1,96^{* *}$
\end{tabular}

a : statistisch gecontroleerd voor leeftijd en sekse

* : $p<0,05$;

**: $p<0,01$ (test van verschillen ten opzichte van ISCED3C short; per land)

\# : $p<0,05$.

\#\# : $p<0,01$ (test van verschillen ten opzichte van Nederland; per opleidingsniveau)

- : niet van toepassing

Bron: Eurostat, EU LFS 2000, eigen berekeningen

\subsubsection{Betaald werk}

In figuur 4.3 is de kans op betaald werk weergegeven voor jongeren die tot de beroepsbevolking behoren, uitgesplitst naar opleidingsniveau en land. Wat verschillen tussen opleidingsniveaus betreft laten de cijfers geen eenduidig beeld zien. Zo geldt in het Verenigd Koninkrijk dat de kans op betaald werk groter is voor degenen met een hoger opleidingsniveau. In Griekenland daarentegen wordt er een negatieve samenhang waargenomen tussen de kans op betaald werk en het hoogst bereikte opleidingsniveau. In Nederland lijkt er helemaal geen verband te bestaan tussen de kans op betaald werk en het hoogst bereikte opleidingsniveau. In Spanje valt vooral op dat de kans op betaald werk voor jongeren met ISCED 3C long aanmerkelijk groter is dan voor jongeren met een ander opleidingsniveau. Wat betreft verschillen in de kans op betaald werk tussen landen komt naar voren dat de arbeidsmarktsituatie in Nederland momenteel het meest gunstig is. Ongeacht het bereikte opleidingsniveau hebben individuen in Nederland de grootse kans op betaald werk. Ten aanzien van ISCED 3C short, bijvoorbeeld, geldt dat in Nederland 95\% van de individuen met dit opleidingsniveau betaald werk verrichten tegenover $71 \%$ in Griekenland. 
Figuur 4.3

Kans op betaald werk, 15-24 jarigen (percentages)

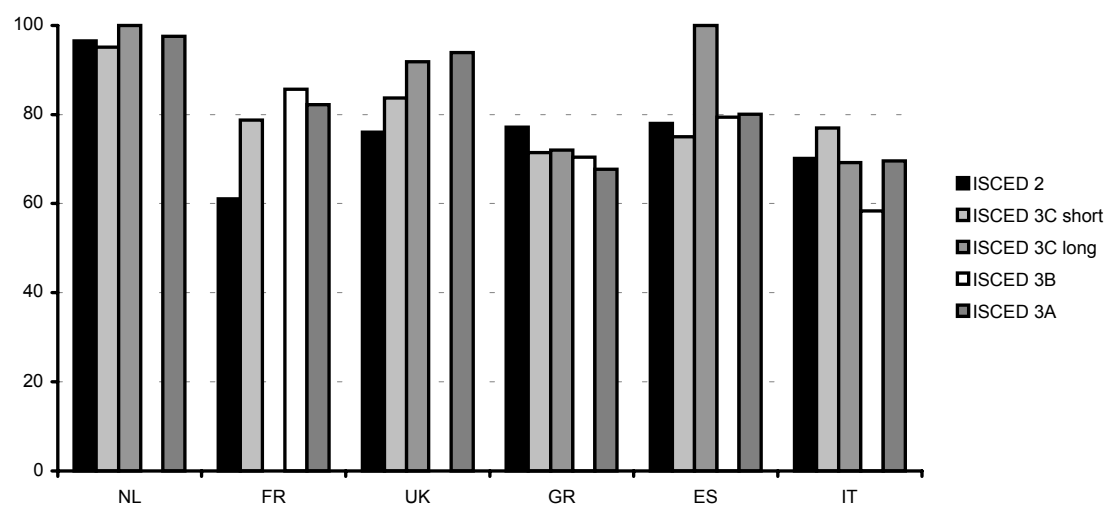

Bron: Eurostat, EU LFS 2000, eigen berekeningen

Tabel 4.5 laat zien dat in Frankrijk, het Verenigd Koninkrijk en Italië de relatieve kans op betaald werk voor individuen met een opleiding op het niveau van ISCED 2 significant lager is dan voor individuen met een opleiding op het niveau van ISCED $3 \mathrm{C}$ short. In Griekenland is de relatieve kans op betaald werk voor degenen met ISCED 2 daarentegen significant groter. Wat betreft ISCED 3C long komt naar voren dat in Nederland en in het Verenigd Koninkrijk de relatieve kans op betaald werk voor jongeren met dit opleidingsniveau significant groter is dan voor degenen met ISCED $3 \mathrm{C}$ short. Het gaat hier slechts om kleine absolute verschillen (zie figuur 4.3). In Italië daarentegen hebben jongeren met een opleiding op het niveau van ISCED $3 \mathrm{C}$ long een kleinere relatieve kans op betaald werk dan degenen met ISCED 3C short. Daarmee wijkt het effect van Italië significant af van het overeenkomstige effect voor Nederland. Wat betreft ISCED 3B geldt dat in Frankrijk de relatieve kans op betaald werk voor degenen met dit opleidingsniveau groter is dan voor degenen met ISCED $3 C$ short. In Italië geldt precies het omgekeerde. Ten aanzien van ISCED 3A tot slot valt op te merken dat in het Verenigd Koninkrijk en Frankrijk de relatieve kans op betaald werk voor jongeren met dit opleidingsniveau significant groter is dan voor degenen met ISCED 3C short, terwijl in Italië de relatieve kans op betaald werk voor jongeren met ISCED 3A juist significant kleiner is. Deze relatieve kans wijkt bovendien significant af van de overeenkomstige relatieve kans in Nederland.

\subsubsection{Vast werk}

Figuur 4.4 gaat in op de kans op vast werk. De figuur laat zien dat - evenals bij de kans op betaald werk - er geen duidelijk patroon tussen de opleidingsniveaus valt waar te nemen. In Nederland hebben jongeren met een opleiding op het niveau van ISCED 3C long de grootste kans op een vaste baan. In Frankrijk hebben degenen met ISCED 3B het vaakst een vaste aanstelling. In Spanje hebben jongeren met ISCED 3A de grootste kans op vast werk; in Italië betreft dit degenen met ISCED 2. In het Verenigd Koninkrijk en Griekenland ten slotte hebben jongeren met een 
opleiding op het niveau van ISCED 3C short de grootste kans op vast werk. Als we kijken naar verschillen tussen landen in de kans op betaald werk dan valt meteen op dat jongeren in Spanje - ongeacht hun opleidingsniveau - de kleinste kans op betaald werk hebben. De grootste kans op vast werk hebben jongeren in het Verenigd Koninkrijk.

Tabel 4.5

Relatieve kans op betaald werk, 15-24 jarigen (logodds ratio's) ${ }^{a}$

\begin{tabular}{llllllc}
\hline Opleidingsniveau & NL & FR & UK & GR & ES & IT \\
\hline ISCED 2 & & & & & & \\
ISCED 3C short & 0,17 & $-0,76^{\star * \#}$ & $-0,48^{* *}$ & $0,50^{* *}$ & 0,36 & $-0,33^{* *}$ \\
ISCED 3C long & 0,00 & 0,00 & 0,00 & 0,00 & 0,00 & 0,00 \\
ISCED 3B & $2,12^{* *}$ & - & $0,78^{\star *}$ & $0,26^{\# \#}$ & 1,41 & $-0,46^{\star \#}$ \\
ISCED 3A & - & $0,41^{* *}$ & - & 0,10 & 0,42 & $-0,91^{*}$ \\
& 0,56 & $0,23^{*}$ & $1,08^{* *}$ & 0,06 & 0,43 & $-0,44^{* \star \#}$ \\
\hline
\end{tabular}

statistisch gecontroleerd voor leeftijd en sekse

*: $p<0,05$

**: $p<0,01$ (test van verschillen ten opzichte van ISCED3C short; per land)

$\#: p<0,05$.

\#: $p<0,01$ (test van verschillen ten opzichte van Nederland; per opleidingsniveau)

- : niet van toepassing

Bron: Eurostat, EU LFS 2000, eigen berekeningen

Figuur 4.4

Kans op vast werk, 15-24 jarigen (percentages)

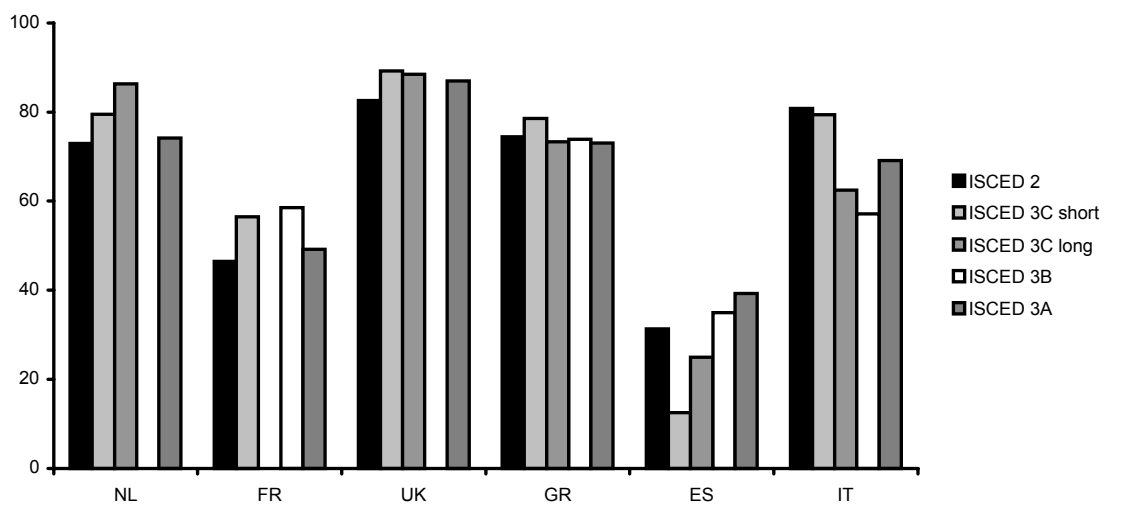

Bron: Eurostat, EU LFS 2000, eigen berekeningen

Wanneer rekening wordt gehouden met verschillen in de samenstelling naar leeftijd en sekse, dan blijkt dat in Frankrijk en het Verenigd Koninkrijk de relatieve kans op vast werk voor individuen met een opleiding op het niveau van ISCED 2 significant lager is dan voor degenen met een opleiding op het niveau van ISCED 3C short (zie tabel 4.6). In Italië is de relatieve kans op vast werk voor degenen met ISCED 2 juist groter. Bovendien wijkt de geschatte logodds ratio significant af van de overeenkomstige schatting voor Nederland. Wat betreft ISCED $3 \mathrm{C}$ long komt naar 
voren dat dit opleidingsniveau in Nederland een grotere relatieve kans op vast werk met zich meebrengt, terwijl hetzelfde opleidingsniveau in Griekenland en Italië gepaard gaat met een kleinere relatieve kans op vast werk. De gevonden effecten voor deze twee landen wijken dan ook significant af van het overeenkomstige effect voor Nederland. Wat betreft ISCED 3B geldt dat Spaanse jongeren met een opleiding op dit niveau een grotere relatieve kans hebben op een vaste baan dan degenen met een opleiding op het niveau van ISCED $3 C$ short. In Italië is het omgekeerde het geval. Als het gaat om ISCED $3 A$ dan zien we dat in alle onderzochte landen jongeren met dit opleidingsniveau een significant kleinere relatieve kans op vast werk hebben dan jongeren met ISCED 3 C short. Een uitzondering wordt gevormd door Spanje waar jongeren met een opleiding op het niveau van ISCED $3 \mathrm{~A}$ juist een significant grotere relatieve kans hebben op een vaste aanstelling.

Tabel 4.6

Relatieve kans op vast werk, 15-24 jarigen (logodds ratio's) ${ }^{a}$

\begin{tabular}{lllllll}
\hline Opleidingsniveau & NL & FR & UK & GR & ES & IT \\
\hline ISCED 2 & $-0,06$ & $-0,29^{* *}$ & $-0,47^{* *}$ & $-0,17$ & $0,95^{* \#}$ & 0,13 \\
ISCED 3C short & 0,00 & 0,00 & 0,00 & 0,00 & 0,00 & 0,00 \\
ISCED 3C long & $0,33^{*}$ & - & $-0,02$ & $-0,38^{\star \# \#}$ & 0,15 & $-1,06^{* *}$ \\
ISCED 3B & - & $-0,01$ & - & $-0,29$ & $0,98^{*}$ & $-1,29^{* *}$ \\
ISCED 3A & $-0,34^{*}$ & $-0,36^{* *}$ & $-0,38^{* *}$ & $-0,33^{*}$ & $1,09^{\star \# \#}$ & $-0,72^{* *}$
\end{tabular}

a : statistisch gecontroleerd voor leeftijd en sekse

* : $p<0,05$;

$\star *: p<0,01$ (test van verschillen ten opzichte van ISCED3C short; per land)

\# : $p<0,05$

\#\# : $p<0,01$ (test van verschillen ten opzichte van Nederland; per opleidingsniveau)

- : niet van toepassing

Bron: Eurostat, EU LFS 2000, eigen berekeningen

\subsubsection{Voltijd werk}

Figuur 4.5 vermeldt de kans op voltijd werk. Wederom zijn de verschillen tussen opleidingsniveaus binnen landen niet eenvoudig te systematiseren. Een patroon dat enigszins te ontdekken valt is dat in een aantal landen jongeren met een opleiding op het niveau van ISCED 2 of ISCED 3A wat minder vaak in deeltijd werkzaam zijn dan jongeren met een ander opleidingsniveau. Dit kan samenvallen met het feit deze groepen opgeleiden ook het meest vaak doorstromen naar een vervolgopleiding (zie figuur 4.1), hetgeen een voltijdbaan in de weg staat. Wat betreft verschillen tussen landen komt naar voren dat in de Zuid-Europese landen Griekenland, Spanje en Italië het meest in voltijd wordt gewerkt. Ongeveer $90 \%$ van de werkzame jongeren daar heeft een voltijd aanstelling. In Nederland, Frankrijk en het Verenigd Koninkrijk daarentegen is het aandeel jongeren dat voltijd werkt met zo'n $75 \%$ een stuk lager. 
Figuur 4.5

Kans op voltijd werk, 15-24 jarigen (percentages)

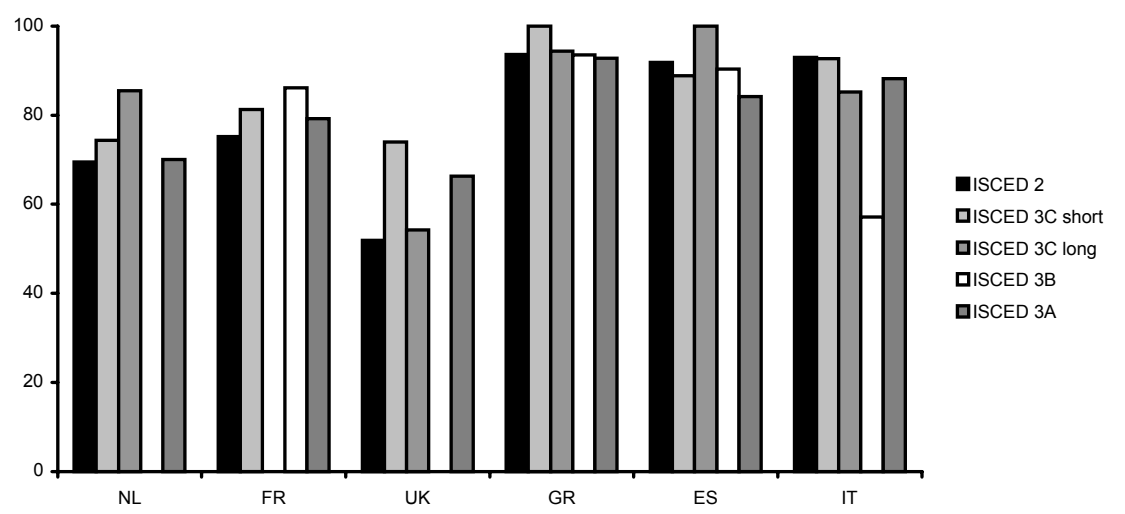

Bron: Eurostat, EU LFS 2000, eigen berekeningen

Tabel 4.7

Relatieve kans op voltijd werk, 15-24 jarigen (logodds ratio's) ${ }^{a}$

\begin{tabular}{lllllll}
\hline Opleidingsniveau & NL & FR & UK & GR & ES & IT \\
\hline ISCED 2 & & & & & & \\
ISCED 3C short & $-0,04$ & $-0,41^{* *}$ & $-0,97^{* \star \# \#}$ & $-0,70$ & 0,48 & $-0,04$ \\
ISCED 3C long & 0,00 & 0,00 & 0,00 & 0,00 & 0,00 & 0,00 \\
ISCED 3B & $0,73^{* *}$ & - & $-0,76^{* * \#}$ & $-0,62^{\#}$ & $-0,00$ & $-0,62^{\star \#}$ \\
ISCED 3A & - & $0,42^{* *}$ & - & $-0,68$ & 0,38 & $-2,12^{\star *}$ \\
& $-0,13$ & 0,20 & $-0,81^{* * \#}$ & $-0,75^{*}$ & $-0,19$ & $-0,44^{* *}$
\end{tabular}

a : statistisch gecontroleerd voor leeftijd en sekse

**: $p<0,01$ (test van verschillen ten opzichte van ISCED3C short; per land)

\# : $p<0,05$

\#: $p<0,01$ (test van verschillen ten opzichte van Nederland; per opleidingsniveau)

- : niet van toepassing

Bron: Eurostat, EU LFS 2000, eigen berekeningen

Uit tabel 4.7 komt naar voren dat - in vergelijking met andere hier onderzochte aspecten van het extern rendement van opleidingen - slechts enkele significante verschillen bestaan tussen opleidingsniveaus als het gaat om de relatieve kans op voltijd werk. Allereerst geldt op het niveau van ISCED 2 dat individuen met zo'n opleiding in Frankrijk en het Verenigd Koninkrijk significant minder vaak in voltijd werkzaam zijn dan degenen met een opleiding op het niveau van ISCED 3C short. De geschatte logodds ratio voor het Verenigd Koninkrijk wijkt daarmee significant af van die voor Nederland. Wat betreft ISCED $3 \mathrm{C}$ long geldt dat jongeren met dit opleidingsniveau in Nederland vaker in voltijd werkzaam zijn dan degenen met een opleiding op het niveau van ISCED $3 \mathrm{C}$ short. In het Verenigd Koninkrijk en Italië daarentegen is het omgekeerde het geval. Als het gaat om ISCED 3B dan zien we dat in Frankrijk jongeren met een opleiding op dit niveau een grotere relatieve kans op voltijd werk hebben dan degenen met ISCED 3C short, terwijl in Italië jongeren met ISCED 3B juist een kleinere relatieve kans op voltijd werk hebben. Voor wat 
betreft ISCED 3A tot slot komt naar voren dat in Griekenland, het Verenigd Koninkrijk en Italië de relatieve kans op voltijd werk voor jongeren met een opleiding op dit niveau kleiner is dan voor hen met een opleiding op het niveau van ISCED 3C short. In de twee laatstgenoemde landen wijkt de geschatte logodds ratio significant af van die voor Nederland.

\subsubsection{Beroepsprestige}

Als laatste aspect van het extern rendement van opleidingen is het bereikte beroepsprestige bestudeerd. In figuur 4.6 zijn de resultaten van deze analyse weergegeven. Uit de figuur blijkt dat het opleidingsniveau van individuen over het algemeen positief samenhangt met hun bereikte beroepsprestige. De verschillen tussen opleidingsniveaus zijn redelijk groot bij aanvang van de beroepsloopbaan. Zo is in Nederland het gemiddeld bereikte beroepsprestige van 15-24 jarigen met een ISCED 2 opleiding 36 statuspunten op een schaal van 16-90, terwijl het gemiddeld bereikte beroepsprestige van degenen met een ISCED 3 A opleiding 42 statuspunten bedraagt. Ook binnen opleidingsniveaus zijn er opmerkelijke verschillen tussen landen. Zo komt naar voren dat in Nederland werkzame jongeren met een opleiding op het niveau van ISCED 2 het hoogste beroepsprestige bereiken - met zoals zojuist vermeld 36 statuspunten -, terwijl overeenkomstig opgeleiden in Spanje het laagste beroepsprestige bereiken (d.w.z. 31 statuspunten). Ten aanzien van ISCED 3C short geldt een soortgelijke verschil. Een dergelijke opleiding levert in Nederland het meest op in termen van beroepsprestige (37 statuspunten), terwijl hetzelfde opleidingsniveau in Spanje het minst oplevert (32 statuspunten). Het hoogste beroepsprestige met een ISCED 3C long opleiding wordt bereikt in Italië; het laagste in het Verenigd Koninkrijk en Nederland. Wat betreft ISCED 3B geldt dat dit opleidingsniveau het meeste waard is Frankrijk en het minst in Spanje en Italië. Een ISCED 3A opleiding ten slotte levert het meest op in Italië en het minst in Griekenland en Spanje.

Figuur 4.6

Bereikte beroepsprestige, 15-24 jarigen (statuspunten)

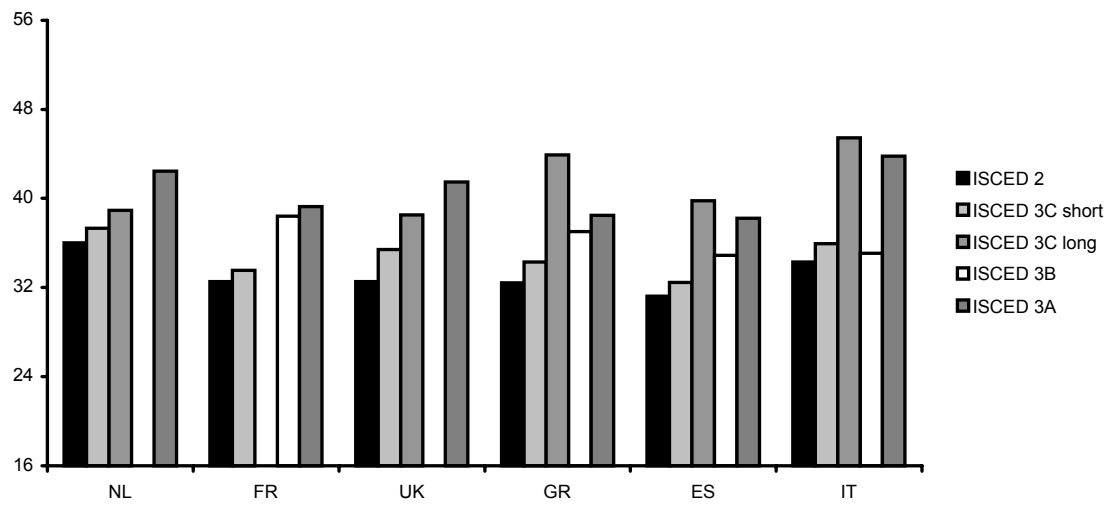

Bron: Eurostat, EU LFS 2000, eigen berekeningen 
Tabel 4.8 laat tot slot verschillen in het bereikte beroepsprestige tussen opleidingsniveaus en landen zien, na correctie voor verschillen in leeftijd en sekse. Uit de resultaten komt naar voren dat het beroepsprestige van personen met een opleiding op maximaal ISCED 2 niveau in alle landen - uitgezonderd Nederland en Spanje significant lager is dan dat van degenen met een opleiding op het niveau van ISCED $3 \mathrm{C}$ short. Voor het Verenigd Koninkrijk is het geschatte verschil -2,61 statuspunten. Daarmee is dit verschil significant groter dan het geschatte verschil in Nederland. Individuen met een ISCED3C long opleiding bereiken daarentegen een significant hoger beroepsprestige dan degenen met een ISCED 3C short opleiding. Dit geldt voor elk land waar dit opleidingsniveau is onderscheiden. Voor Nederland bedraagt het geschatte verschil 1,49 statuspunten. Dit verschil is voor Italië, Griekenland en het Verenigd Koninkrijk echter significant groter. Verschillen tussen ISCED 3B en ISCED 3C short zijn alleen voor Frankrijk en Griekenland significant. Zo bereiken werkzame jongeren met een opleiding op het niveau van ISCED 3B in Frankrijk bijna 5 statuspunten meer dan degenen met een ISCED 3C short opleiding. Met betrekking tot ISCED 3A geldt dat in alle onderzochte landen individuen met dit opleidingsniveau een hoger beroepsprestige bereiken dan individuen met ISCED 3C short. Voor Italië is het geschatte verschil significant groter dan voor Nederland.

Tabel 4.8

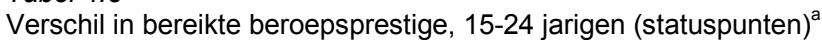

\begin{tabular}{lcccccc}
\hline Opleidingsniveau & NL & FR & UK & GR & ES & IT \\
\hline & & & & & \\
ISCED 2 & $-0,56$ & $-0,84^{*}$ & $-2,61^{* * \#}$ & $-2,09^{* *}$ & $-1,22$ & $-1,60^{* *}$ \\
ISCED 3C short & 0,00 & 0,00 & 0,00 & 0,00 & 0,00 & 0,00 \\
ISCED 3C long & $1,49^{*}$ & - & $3,08^{* \star \#}$ & $7,34^{* * \#}$ & $7,20^{*}$ & $9,45^{\star \star \#}$ \\
ISCED 3B & - & $4,76^{* *}$ & - & $1,63^{*}$ & 2,04 & $-1,11$ \\
ISCED 3A & $5,04^{* *}$ & $5,27^{* *}$ & $5,42^{* *}$ & $2,75^{* * \#}$ & $5,21^{* *}$ & $7,83^{* \star \#}$
\end{tabular}

a : statistisch gecontroleerd voor leeftijd en sekse

* : $p<0,05$

**: $p<0,01$ (test van verschillen ten opzichte van ISCED3C short; per land)

$\#: p<0,05$

\#\# : p < 0,01 (test van verschillen ten opzichte van Nederland; per opleidingsniveau)

- : niet van toepassing

Bron: Eurostat, EU LFS 2000, eigen berekeningen

\subsection{Samenvatting en conclusie}

Om de waarde van de Nederlandse startkwalificatie te bepalen is in dit hoofdstuk de (arbeidsmarkt)positie van jongeren met een opleiding op het niveau van ISCED 3C short internationaal vergeleken. Op empirische wijze is nagegaan in hoeverre het extern rendement van ISCED $3 C$ short opleidingen verschilt tussen Nederland en enkele andere Europese landen, waaronder Frankrijk en het Verenigd Koninkrijk. Hiertoe is gebruik gemaakt van gegevens uit de European Union Labour Force Survey (EU LFS) van 2000. Deze vergelijking heeft een aantal interessante bevindingen opgeleverd waarvan de resultaten in tabel 4.9 zijn samengevat. In de tabel is aangegeven tussen welke opleidingsniveaus een relatief sterke verbetering optreedt in de verschillende aspecten van het extern rendement. Hiervoor zijn de 
analyseresultaten uit de tabellen 4.3 tot en met 4.8 als uitgangspunt genomen. In het geval dat er sprake is van inconsistente patronen (bijvoorbeeld een relatieve verslechtering van de arbeidsmarktpositie bij verhoging van het opleidingsniveau) is een vraagteken ingevuld.

Tabel 4.9

Bepaling van de grens voor relatief sterk verbeteringen op basis van de zes onderzochte aspecten van het extern rendement van opleidingen, per land

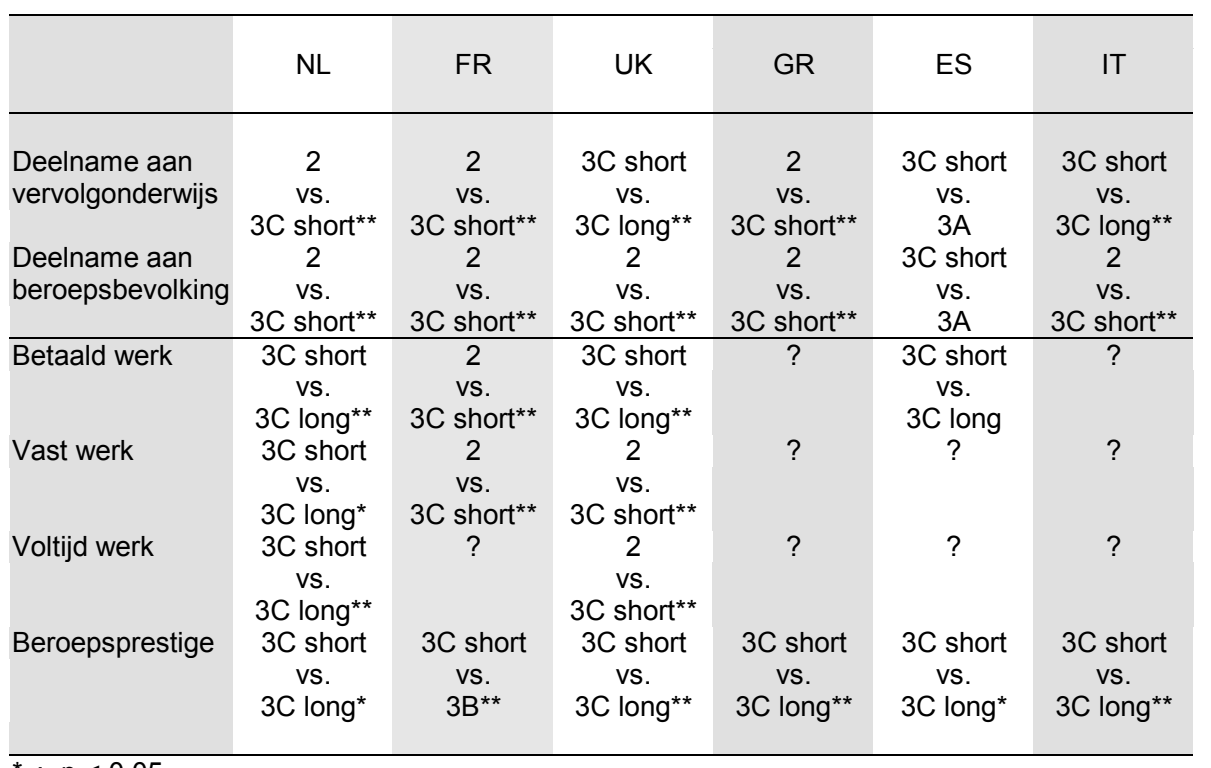

*: $\mathrm{p}<0,05$

**: $p<0,01$

$?$ : verschillen tussen opleidingsniveaus inconsistent of te gering

Bron: Eurostat, EU LFS 2000, eigen berekeningen

Op basis van tabel 4.9 kan worden geconcludeerd dat met betrekking tot de vraag welk opleidingsniveau toeleidt naar de arbeidsmarkt, de meeste verschillen zich voordoen tussen de niveaus ISCED 2 en ISCED 3C short. Dit geldt allereerst voor de deelname aan vervolgonderwijs. In de onderzochte landen is ISCED 2 geen eindonderwijs, terwijl ISCED 3C short (grotendeels) wel als eindonderwijs kan worden beschouwd. Voor het Verenigd Koninkrijk geldt wellicht een uitzonderingspositie. Daar ligt de grens eerder tussen ISCED 3C short en ISCED 3C long. Hier staat echter tegenover dat de deelname aan de beroepsbevolking onder jongeren met ISCED 2 in het Verenigd Koninkrijk een heel stuk lager is dan onder degenen met een opleiding op het niveau van ISCED 3C short. Dit geldt ook voor alle andere onderscheiden landen.

Ten aanzien van het bereikte beroepsprestige zijn de grootste verschillen te vinden tussen de niveaus ISCED 3 C short en ISCED 3 C long. Jongeren met een opleiding op het niveau van ISCED 3 C short bereiken een lager beroepsprestige dan degenen met een opleiding op het niveau van ISCED 3C long. Hoewel er in de meeste landen - uitgezonderd Nederland en Spanje - ook een verschil in bereikt beroepsprestige bestaat tussen jongeren met ISCED 2 en ISCED 3C short, is dit verschil - met 
uitzondering van het Verenigd Koninkrijk wellicht - aanzienlijk kleiner dan het verschil tussen de niveaus ISCED 3C short en ISCED 3C long. In Frankrijk bevindt het onderscheid zich overigens - bij afwezigheid van niveau ISCED $3 C$ long - tussen opleidingen op het niveau van ISCED 3C short en ISCED 3B.

Voor de overige aspecten van het extern rendement van opleidingen (kansen op betaald werk, vast werk en voltijd werk) verschillen de uitkomsten per land. Voor Frankrijk en het Verenigd Koninkrijk is sprake van een relatief sterke verbetering tussen ISCED 2 en ISCED 3C short. Voor Nederland daarentegen komt duidelijk naar voren dat de grens tussen ISCED $3 C$ short en ISCED 3 C long ligt. In Nederland bieden opleidingen op het niveau van ISCED 3 C short relatief minder goede kansen op betaald werk, vast werk en voltijd werk dan opleidingen op het niveau van ISCED 3C long. Wel moet hierbij aangetekend worden dat in absolute termen gezien de kans op betaald werk voor Nederlandse schoolverlaters op niveau ISCED 2 en ISCED 3C short beduidend hoger ligt dan zelfs de hogere opleidingsniveaus in het buitenland. Voor de overige landen (Italië, Griekenland en Spanje) is het patroon dusdanig inconsistent dat geen duidelijke demarcatielijn kan worden getrokken.

Wat kan op basis van deze bevindingen worden geconcludeerd over de waarde van de Nederlandse startkwalificatie vanuit een internationaal perspectief? De resultaten die in dit hoofdstuk zijn gepresenteerd, tonen aan dat wat betreft de voorbereiding op de arbeidsmarkt de grootste verschillen zich voordoen tussen de opleidingsniveaus ISCED 2 en ISCED 3C short. Nederland loopt daarbij aardig in de pas met andere Europese landen. Als naar het bereikte beroepsprestige wordt gekeken, dan manifesteren de grootste verschillen zich tussen de niveaus ISCED 3C short en ISCED 3 C long. Ook hier geldt weer dat de Nederlandse situatie niet echt afwijkt van andere landen. Maar als het gaat om kansen op betaald werk, vast werk en voltijd werk, dan geldt met name voor Nederland dat ook bij deze arbeidsmarktuitkomsten de grens tussen ISCED 3C short en ISCED 3C long ligt. Met andere woorden: in Nederland bereidt een opleiding op het niveau van ISCED $3 C$ short jongeren voor op de arbeidsmarkt, maar of het hen daarmee ook voldoende startbekwaam maakt is de vraag. In ieder geval valt de relatieve verbetering die geboekt kan worden met een opleiding op het niveau van ISCED 3 C short in Nederland wat tegen.

Dit lijkt in tegenspraak met de bevindingen uit het vorige hoofdstuk. In het slothoofdstuk zullen we uitgebreid stilstaan bij de verschillen tussen beide typen analyses en de interpretatie daarvan. Wel willen we hier reeds twee kanttekeningen plaatsen bij de huidige analyse. In de eerste plaats is het mogelijk dat de specifieke bevindingen voor Nederland te maken hebben met het feit dat in dit land relatief veel schoolverlaters met een opleiding op het niveau van (ISCED 2 of) ISCED 3C short nog een opleiding in het leerlingwezen volgen en dus om die reden vaker part-time werken en een tijdelijke aanstelling hebben. In de analyse is geprobeerd hiermee rekening te houden door alle personen die op het moment van ondervraging strikt genomen tot de beroepsbevolking zouden behoren, maar tegelijkertijd deelnemen aan een initiële opleiding, uit te sluiten van de beroepsbevolking. Het is echter twijfelachtig of in de gebruikte gegevens het leerlingwezen ook altijd als initieel onderwijs is beschouwd. In de tweede plaats tonen de absolute cijfers een positiever 
beeld over Nederland. Zo is in Nederland dankzij de huidige hoogconjunctuur de kans op betaald werk voor jongeren met een opleiding op het niveau van ISCED 3C short groter dan in andere landen. Ook bereiken zij momenteel het hoogste beroepsprestige vergeleken met andere landen. 


\section{$5 \quad$ Samenvatting en conclusies}

\subsection{De belangrijkste bevindingen}

Een belangrijk beleidsstreven van de Nederlandse overheid is om zoveel mogelijk jongeren een zogenaamde startkwalificatie te laten behalen, dat wil zeggen een opleiding op minimaal niveau 2 van de kwalificatiestructuur. De veronderstelling hierachter is dat dit opleidingsniveau minimaal noodzakelijk is om goed te kunnen functioneren op de arbeidsmarkt. Ondanks het feit dat dit een van de belangrijkste doelstellingen is in het onderwijsbeleid gericht op schoolverlaters van de eerste fase voortgezet onderwijs, is in empirische zin betrekkelijk weinig bekend over deze problematiek. Zo wordt niet systematisch bijgehouden hoeveel jongeren uit een leeftijdscohort nu een startkwalificatie behalen, en is ook weinig bekend over de opbrengsten van een startkwalificatie in vergelijking tot andere opleidingsniveaus.

In dit rapport zijn de opbrengsten van opleidingen op niveau 2 van de BOL en de $B B L$ vergeleken met de opleidingen die qua niveau daar vlak onder zitten (niveau 1 en VBO) en de opleidingen die er boven zitten (niveau 3 en 4). Daarnaast is een internationale vergelijking gemaakt waarbij is nagegaan wat de positie is van de opleidingen op ISCED niveau $3 C$ short vergeleken met ISCED niveau 2 enerzijds en de overige opleidingen op niveau 3 (3A, 3B en $3 \mathrm{C}$ long) anderzijds.

In de analyse is een accent gelegd op de vraag of de relatie tussen opleidingsniveau en opbrengsten monotoon verloopt, zoals sommige theorieën voorspellen, of dat er sprake is van bepaalde discontinuïteiten. Dit onderscheid is van belang omdat ze mede een antwoord kan geven op de vraag welk opleidingsniveau als startkwalificatie betiteld moet worden. In het geval dat de relatie tussen aantal jaren scholing en opbrengsten monotoon verloopt, zullen maatschappelijke overwegingen de doorslag moeten geven welk opleidingsniveau als minimaal wordt beschouwd om goed te kunnen functioneren op de arbeidsmarkt. Deze overwegingen kunnen echter niet rechtstreeks uit de empirie worden afgeleid. Wanneer echter de relatie discontinu verloopt, dan kan een mogelijke grens gelegd worden bij dat opleidingsniveau waar de relatieve verbetering als gevolg van één jaar additionele scholing het grootst is. ${ }^{8}$ Met name segmenteringstheorieën en institutionele theorieën bieden een verklaring voor het mogelijk bestaan van dergelijke discontinuïteiten. Zo kan het minimum jeugdloon tot gevolg hebben dat schoolverlaters over een minimaal opleidingsniveau moeten beschikken om de productiviteit te garanderen die met dit jeugdloon overeenkomt. Een andere mogelijke oorzaak voor een discontinuïteit zou gelegen kunnen zijn in de segmentering van de arbeidsmarkt op grond van kwalificatievereisten. In de optiek van de gesegmenteerde arbeidsmarkt is een minimaal kwalificatieniveau noodzakelijk om toegang te verschaffen tot de bedrijfsspecifieke of vakspecifieke deelmarkten. Schoolverlaters die niet over een dergelijke minimale kwalificatie beschikken zijn aangewezen op de banen in het secundaire

8. Ook dat laat overigens onverlet dat op grond van maatschappelijke overwegingen de startkwalificatie op een ander niveau gedefinieerd zou kunnen worden. 
segment: banen van een laag niveau met slechte primaire en secundaire arbeidsvoorwaarden.

Voor de analyse is gebruik gemaakt van twee soorten databronnen: de schoolverlatersenquêtes van het ROA en de European Union Labour Force Surveys (EU LFS). De eerste databron maakt het mogelijk om op een heel gedetailleerd niveau de arbeidsmarktsituatie van schoolverlaters in ogenschouw te nemen. Groot voordeel daarvan is vooral de mogelijkheid die de in het schoolverlatersonderzoek gebruikte opleidingsclassificatie biedt voor een exacte operationalisering van voor het beleid relevante niveaus, alsmede de hoeveelheid beschikbare indicatoren over de arbeidsmarktpositie van schoolverlaters. Bovendien is de steekproefopzet direct toegesneden op een analyse van de positie van schoolverlaters. Het voordeel van de tweede databron is de mogelijkheid tot internationale benchmarking.

De belangrijkste conclusies zijn van beide analyses zijn als volgt samen te vatten:

1. In de Nederlandse situatie ligt een belangrijk onderscheid tussen VBO enerzijds en BOL/BBL niveau 1 anderzijds als het gaat om de vraag wat als eindonderwijs moet worden beschouwd. Een vergelijkbaar onderscheid zien we terug in de onderscheiden EU landen, waar ISCED 2 niet als eindonderwijs en ISCED 3C short wel (voor een belangrijk deel) als eindonderwijs wordt beschouwd. Bovendien ligt de deelname aan de beroepsbevolking voor de opleidingen op ISCED niveau 3C short veel hoger dan voor ISCED 2. In die zin kan men zeggen dat opleidingen op niveau 1 en de ISCED $3 C$ short opleidingen (mede) voorbereiden op de arbeidsmarkt, hoewel daarmee nog niet is gezegd of ze de schoolverlaters daarvoor ook voldoende toerusten.

2. Als het gaat om de kans op betaald werk, vast werk en voltijd werk, dan verschillen de uitkomsten tussen de beide soorten analyses. Concentreren we ons op de internationale vergelijking, dan valt vooral op dat de uitkomsten per land sterk uiteenlopen. Voor Frankrijk en het Verenigd Koninkrijk lijkt de grens getrokken te moeten worden tussen niveau ISCED 2 en ISCED 3C short, maar daarbij dient aangetekend te worden dat het bewijs hiervoor maar voor twee van de drie indicatoren geleverd wordt. In het geval van Nederland wijzen alle drie indicatoren op een demarcatie tussen niveau ISCED 3C short en ISCED 3C long. Voor de overige landen is het patroon dusdanig inconsistent dat daar geen duidelijke demarcatie gevonden kan worden.

3. Bij de analyse van de Nederlandse schoolverlatersdata blijken de grootste verschillen tussen de opleidingsniveaus voor wat betreft de kans op betaald werk gevonden te worden tussen $\mathrm{VBO}$ en niveau 1 bij de $\mathrm{BOL}$ en tussen niveau 1 en niveau 2 bij de BBL. In beide gevallen echter zijn de verschillen niet significant te zijn. Voor de kans op een vast dienstverband zijn die significante verschillen er wel. Voor de opleidingen in BOL ligt het grootste onderscheid tussen de niveaus 2 en 3 en bij de opleidingen in BBL tussen VBO en niveau 1.

4. Voor de schoolverlatersdata zijn ook analyses mogelijk waarbij de kwalitatieve aansluiting tussen opleiding en beroep centraal staat. Daarbij gaat het om het niveau van de verworven banen en om de aansluiting van de baan bij de gevolgde richting. Hier is het beeld wat gemixt. Waar het gaat om het niveau van de baan, ligt het onderscheid bij de BOL tussen niveau 1 en 2, maar bij de BBL 
tussen niveau 2 en niveau 3. Bij de aansluiting van de baan bij de gevolgde opleidingsrichting is het net andersom, al moet daarbij worden aangetekend dat in het geval van de BOL het onderscheid tussen niveau 2 en 3 net zo groot is als tussen niveau 1 en 2 (zij het dat het laatste onderscheid niet significant is).

5. Als het gaat om de beloning, dan blijken de Nederlandse schoolverlaters de grootste relatieve verbetering te realiseren bij de overgang van VBO naar niveau 1. Dit geldt zowel voor de BOL als voor de BBL. Vergelijkbare gegevens ontbreken bij de internationale data.

6. Bij de analyse van het bereikte beroepsprestige laten de onderzochte landen een duidelijk verschil tussen opleidingen op niveau van ISCED $3 \mathrm{C}$ short en $3 \mathrm{C}$ long zien. Jongeren met laatstgenoemde opleidingsniveau bereiken gemiddeld genomen een hoger beroepsprestige.

\subsection{Verschillen in uitkomsten}

Een problematisch gegeven is dat de beide analyses deels in verschillende richting wijzen. Concentreren we ons op de data van de EU LFS, dan moeten we voor Nederland concluderen dat de grootste relatieve verbetering te vinden is in de overgang van ISCED $3 C$ short naar ISCED 3 C long. Kijken we echter naar de Nederlandse schoolverlatersdata, dan blijkt de grootste relatieve verbetering te vinden bij de overgang van niveau 2 (is ISCED 2) naar niveau 3 (is ISCED 3C short) van de kwalifcatiestructuur. Hoe kunnen deze verschillen verklaard worden? In hoofdlijn zijn er drie belangrijke oorzaken: verschillen in de aard van de indicatoren, verschillen in meetjaar en verschillen in steekproefdesign.

De Nederlandse schoolverlatersdata omvatten meer en betere indicatoren voor de arbeidsmarktpositie van schoolverlaters dan de EU LFS. Met name indicatoren als kans op betaald werk, niveau van de baan, aansluiting naar richting en beloning gelden als goede indicatoren voor de waarde van een opleiding (ROA, 2002). Van schoolverlaters is bekend dat ze in de regel voltijds werkzaam zijn, behalve wanneer ze een opleiding in het kader van het leerlingwezen volgen. Dan zijn ze per definitie in deeltijd werkzaam (ROA, 2002). Ook is bekend dat tijdelijke aanstellingen niet altijd hoeven te wijzen op een slechte arbeidsmarktpositie. Met name banen die gecombineerd worden met een opleiding (bv. leerlingwezen; AIO's; trainees), hebben vaak een tijdelijk karakter, namelijk voor de duur van de opleiding. Het beroepsprestige geeft wel een goede indicatie van de algemene sociale waardering van beroepen, maar dit hoeft niet één op één te sporen met de economische waardering op de arbeidsmarkt. Het is daarom ook niet zo heel verrassend dat het grootste onderscheid gevonden wordt tussen niveau $3 \mathrm{C}$ short en $3 \mathrm{C}$ long, omdat dat ook een grens markeert tussen typisch blauwe boorden en witte boorden beroepen. Dat hoeft echter nog niet te impliceren dat een opleiding voor de geschoolde blauwe boorden beroepen geen goede startkwalificatie leveren.

Een tweede oorzaak van het verschil tussen beide typen analyses kan gelegen zijn in het verschil in meetjaar. De schoolverlatersdata hebben betrekking op de metingen die verricht zijn in 1999 en 2000. De steekproef bestaat uit schoolverlaters die ongeveer anderhalf jaar op de arbeidsmarkt zitten. Daarmee bestrijken deze data 
een periode van grofweg 1998 tot 2000 . De EU LFS data hebben betrekking op de meting van 2000. De steekproef uit de analyse bestaat uit schoolverlaters in de leeftijd van 15 tot 24 jaar. Afhankelijk van de gevolgde opleiding kan men tot maximaal 8 jaar arbeidservaring hebben. Daarmee bestrijkt deze analyse grofweg de periode die loopt van 1992 tot 2000, met een accent op de tweede helft van deze periode. De betreffende periode heeft een sterk dynamiek gekend in de arbeidsmarktcondities voor schoolverlaters met een sterke stijging van de werkloosheid tot 1996, gevolgd door een scherpe daling tot 2000 . Het is mogelijk dat de analyse die betrekking had op de schoolverlatersdata een te rooskleurig beeld geeft voor met name de laagstopgeleiden. Het zou kunnen dat in een periode van economische teruggang de demarcatie tussen relatief goed presterende en relatief slecht presterende opleidingen naar boven schuift. Dit is ook precies wat voorspeld zou worden in de screeningstheorie (zie hoofdstuk 2). Of dat ook empirisch het geval is valt op dit moment nog niet te zeggen. De analyses met de EU LFS lijken in die richting te wijzen, maar die verschillen kunnen even goed verklaard worden door verschillen in het steekproefdesign (zie hierna). Het verdient daarom aanbeveling om de analyse voor de Nederlandse schoolverlatersdata nog eens te herhalen met gebruik van meerdere meetjaren.

Zoals hierboven is aangegeven kan het verschil tussen beide analyses ook verklaard worden door verschillen in steekproefdesign. In het ene geval wordt een uitstroomcohort geanalyseerd die verschillen in opleiding en leeftijd, maar niet in arbeidservaring. Door in de analyse te controleren voor leeftijd wordt geprobeerd het 'zuivere' opleidingseffect te schatten. In de andere analyse wordt een leeftijdsgroep geanalyseerd (15-24 jarigen), die verschillen in opleiding, maar ook - per definitie in arbeidservaring. De laagst opgeleiden in dat cohort hebben ook de meeste arbeidservaring. Door deze extra arbeidservaring compenseren ze een deel van de achterstand die ze hebben ten opzichte van de hoger opgeleiden. Dit kan als volgt grafisch worden weergegeven. Figuur 5.1 geeft een hypothetisch voorbeeld van de effecten van opleidingen 1, 2 en 3 op het inkomen. Verondersteld wordt dat de schoolverlaters van opleiding 1 meer arbeidservaring hebben dan de schoolverlaters van de opleidingen 2 en 3 . Zonder controle voor arbeidservaring, lijkt het alsof de relatief grootste verbetering te realiseren is bij de overgang van opleiding 2 naar opleiding 3. Kijken we echter naar de verschillen met controle voor arbeidservaring, dan blijkt de grootste sprong gerealiseerd te worden bij de overgang van opleiding 1 naar opleiding 2. Een dergelijk effect lijkt zich ook voor te doen bij de analyse van de EU LFS. Weliswaar is geprobeerd hiervoor te controleren door in de multivariate analyse een dummyvariabele op te nemen voor leeftijd (20-24 versus 15-19), maar wellicht is dat onvoldoende precies. Een aanwijzing hiervoor blijkt uit het feit dat een vergelijkbare analyse op de gehele beroepsbevolking (zie appendix 1) een ander beeld oplevert. Het voordeel van een analyse over de gehele beroepsbevolking is dat het effect van arbeidservaring voor de onderscheiden opleidingsniveaus grosso modo even groot is. Uit deze analyse blijkt dat de grens toch weer vaker tussen ISCED 2 en ISCED 3 C short gelegd moet worden. 
Figuur 5.1

Hypothetische effecten van opleiding en arbeidservaring op inkomen

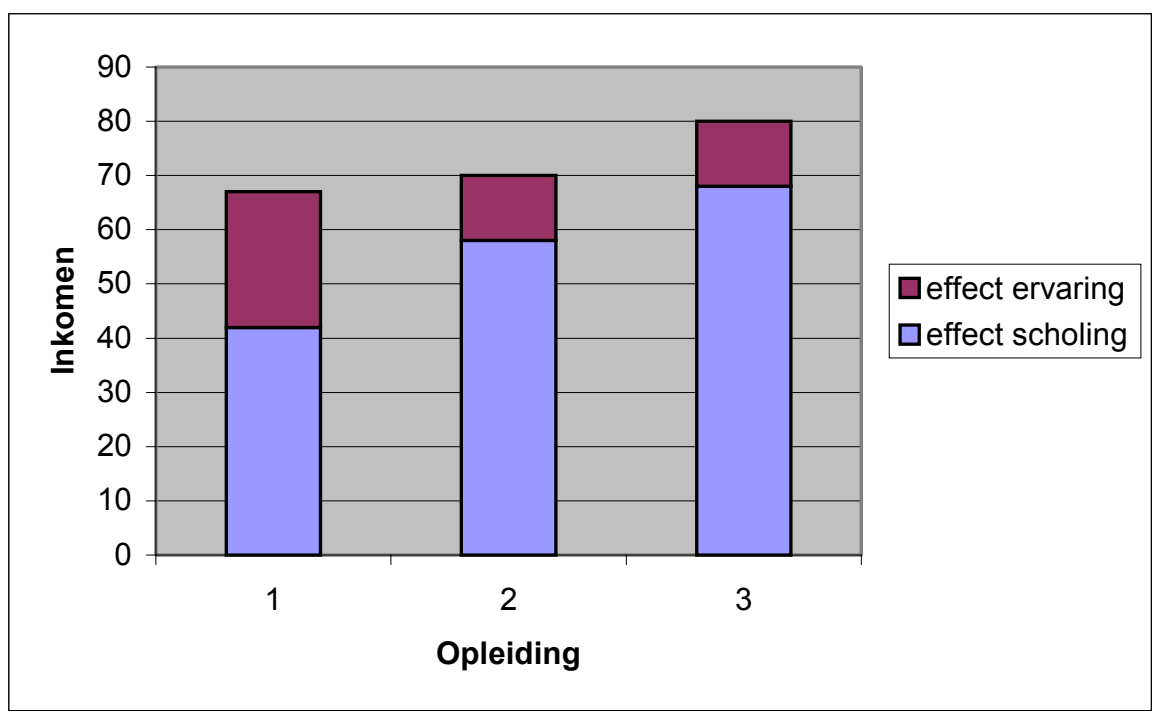

\subsection{Conclusies}

Zoals eerder is aangegeven kan het beleid om zoveel mogelijk jongeren een opleiding te laten halen op het niveau van - wat in de Nederlandse context wordt aangeduid met de term - startkwalificatie, gebaseerd worden op zowel maatschappelijke overwegingen als op empirische gronden. Over de maatschappelijke overwegingen hebben we ons in dit rapport niet uitgelaten. Op empirische gronden echter kunnen we concluderen dat op basis van de analyse voor Nederlandse schoolverlaters voor een groot aantal - doch niet alle - indicatoren geconstateerd kan worden dat niveau 2 van de kwalificatiestructuur relatief goede opbrengsten genereert op de arbeidsmarkt. Voor een aantal indicatoren blijkt zelfs een opleiding op niveau 1 al een aanmerkelijke verbetering te zijn ten opzichte van het VBO. Daarmee lijkt het gekozen niveau 2 als startkwalificatie redelijk adequaat te zijn.

Bij deze conclusie dient echter een belangrijk voorbehoud gemaakt te worden. De analyses die in dit rapport zijn gepresenteerd hebben betrekking op de arbeidsmarktsituatie voor Nederlandse schoolverlaters op het eind van de jaren 1999 en 2000 , een periode waarin sprake was van een zeer gespannen arbeidsmarkt. Hierdoor verschuift de waardering van opleidingen alsmede de grens van wat op de arbeidsmarkt wel en niet wordt gewaardeerd. Het is goed mogelijk dat in een periode van economische neergang de grens verschuift naar hogere opleidingen. Dit is wat op grond van de wachtrijtheorie (Thurow, 1975) voorspeld wordt, maar of dat empirisch ook klopt is nog de vraag. Daarvoor is een analyse over een langere tijdsperiode gewenst. Het lijkt daarom verstandig om het onderzoek over enige tijd nog eens te herhalen. Dat is te meer van belang om ook beter zicht te krijgen op de waarde van opleidingen die betrekkelijk nieuw zijn, zoals de meeste opleidingen op niveau 1. 
De uitkomsten van het internationale onderzoek geven aanleiding om de opleidingen op ISCED niveau $3 \mathrm{C}$ short in ieder geval te beschouwen als eindonderwijs met een belangrijke allocatiefunctie naar de arbeidsmarkt. Of de betreffende opleidingen de schoolverlaters ook voldoende uitrusten om goed op de arbeidsmarkt te kunnen functioneren is echter nog de vraag. Voor Frankrijk en het Verenigd Koninkrijk lijkt het antwoord voorzichtig positief te zijn. Voor Nederland lijkt het antwoord eerder negatief te zijn, maar er zijn redenen om daaraan te twijfelen. Daarbij lijkt vooral een gevaar te schuilen in het gebruik van leeftijdscohorten, indien onvoldoende gecorrigeerd kan worden voor het aantal jaren arbeidservaring. Bij gebrek aan een goede indicator hiervoor, kan ook gewerkt worden met een ruwe benadering van een leeftijdsrelevant cohort. Een dergelijke methodiek is gebruikt in Müller et al. (te verschijnen). Zij construeren per ISCED niveau per land een relevante leeftijdsrange op basis van de voor dat land en dat ISCED niveau gebruikelijke leeftijd van schoolverlaten.

De theoretische implicaties van de analyses lijken te wijzen in de richting van de segmenteringstheorie. De geconstateerde discontinuïteiten sluiten een verklaring op basis van institutionele loonvorming uit. Het stelsel van minimum jeugdloon heeft immers tot gevolg dat de verschillen aan de onderkant kleiner worden in plaats van groter. De analyses wijzen echter uit dat de grootste discontinuïteiten zich bevinden aan de onderkant van het loongebouw tussen VBO en niveau 1. De bevindingen zijn daarentegen wel in lijn met wat voorspeld zou worden op basis van de segmenteringstheorie. Schoolverlaters van het VBO en gedeeltelijk ook niveau 1 van het secundair beroepsonderwijs zijn grotendeels aangewezen op banen in het secundair segment, waar weinig of geen specifieke competenties voor vereist zijn. Dit uit zich in lagere kansen op werk, minder werkzekerheid en slechtere arbeidsvoorwaarden. De opleidingen op niveau 2 en daarboven bieden de schoolverlaters toegang tot de banen in de beroepsspecifieke deelmarkten en de interne arbeidsmarkten. Dit gaat gepaard met een hogere beloning, meer werkzekerheid, en een groter belang van het niveau en de richting van de gevolgde opleiding. 


\section{$6 \quad$ Literatuur}

Adviescommissie Onderwijs-Arbeidsmarkt (1990), Onderwijs-arbeidsmarkt: naar een werkzaam traject, Samson H.D. Tjeenk Willink, Alphen aan de Rijn.

Becker, G.S. (1964), Human capital: a theoretical and empirical analysis with special reference to Education, NBER, New York.

Bernelot Moens, W. (2000), ISCED 1997 en het Nederlandse onderwijs. In: CBS, Kwartaalschrift Onderwijsstatistieken 2000-IV, Voorburg: Centraal Bureau voor de Statistiek.

Droste, J.F.M., Grönloh, J.H.O. \& Hövels, B.W.M. (1993), Startkwalificaties voor iedereen, maar hoe bereik je dat? In: J.F.M. Droste \& J.H.O. Grönloh (ed.), Startkwalificaties voor iedereen, maar hoe bereik je dat? pp. 11-33, Enschede/Den Bosch: SLO, CIBB.

Eijs, P. van \& Farag, S. (2002), Het rendement van de opleidingskeuze van schoolverlaters van het $V B O$ en de MAVO, Maastricht: ROA.

Ganzeboom, H., Graaf, P. de \& Treiman, D. (1992), A standard international socio-economic index of occupational status. Social Science Research, 21, 1-56.

Ganzeboom, H. \& Treiman D. (1996), Internationally comparable measures of occupational status for the 1998 International Standard Classification of Occupations, Social Science Research, 25, 201-239.

Hartog, J. (2000), 'On returns to education: wandering along the hills of oru land', in: Heijke, H, en J. Muysken (red.), Education and training in a knowledge-based economy, MacMillan Press, Houndsmills.

ILO (1990), Statistical sources and methods, [Volume 3: Economically active population, employment, unemployment and hours of work (household surveys), second edition.] Geneva: International Labour Organisation.

Jong, U. de \& Berkenbosch, J. (2001), Toegankelijkheid, In: Velden, R. van der (red.), Toegankelijkheid, intern rendement en doorstroom, pp. 95-132, Zoetermeer: Stuurgroep Evaluatie WEB.

Lutz, B. \& W. Sengenberger (1974), Arbeitsmarktstrukturen und öffentliche Arbeitsmarktpolitik, Otto Schwartz \& Co., Göttingen.

Ministerie van Onderwijs, Cultuur en Wetenschappen (1993a), Blijven Leren: ontwikkelperspectief voor de volwasseneneducatie in brede zin, Den Haag.

Ministerie van Onderwijs, Cultuur en Wetenschappen (1993b), Naar een goed voorbereide start, Den Haag.

Ministerie van Onderwijs, Cultuur en Wetenschappen (2002), Onderwijs, Cultuur en Wetenschappen in kerncijfers 2003, Den Haag.

Müller, W., Gangl, M., Couppié, Th., Mansuy, M., Velden, R. van der, \& Wolbers, M. (te verschijnen), Transitions from education to work in Europe. The integration of youth in EU labour markets, Oxford: Oxford University Press.

Nijhof, W.J. \& Sterumer, J.N. (1994), Verbreed beroepsonderwijs, Academisch Boeken Centrum ABC, De Lier.

OECD (1999), Classifying educational programmes. Manual for ISCED-97. Implementation in OECD Countries, 1999 Edition, Paris: Organisation for Economic Co-operation and Development.

OECD (2000), From initial education to working life: making transitions work, Paris: Organisation for Economic Co-operation and Development.

OECD (2001), Education at a Glance, Paris: Organisation for Economic Co-operation and Development.

Researchcentrum voor Onderwijs en Arbeidsmarkt (1999), Schoolverlaters tussen onderwijs en arbeidsmarkt 1998, Maastricht: ROA. 
Researchcentrum voor Onderwijs en Arbeidsmarkt (2001), Schoolverlaters tussen onderwijs en arbeidsmarkt 2000, Maastricht: ROA.

Researchcentrum voor Onderwijs en Arbeidsmarkt (2002), Schoolverlaters tussen onderwijs en arbeidsmarkt 2001, Maastricht: ROA.

Thurow, L.C. (1975), Generating inequality, Basic Books, New York.

Velden, R. van der (red.) (2001), Toegankelijkheid, intern rendement en doorstroom, Zoetermeer: Stuurgroep Evaluatie WEB.

Wolbers, M., De externe effecten van het secundair beroepsonderwijs, In: Velden, R. van der (red.), Toegankelijkheid, intern rendement en doorstroom, pp. 175-202, Zoetermeer: Stuurgroep Evaluatie WEB. 


\section{Appendix A}

Tabel A1

Relatieve kans op betaald werk, 15-64 jarigen (logodds ratio's) ${ }^{a}$

\begin{tabular}{lcclccc}
\hline Opleidingsniveau & NL & FR & UK & GR & ES & IT \\
\hline ISCED 1-2 & & & & & & \\
ISCED 3C short & 0,54 & $-0,71^{* *}$ & $-0,58^{* *}$ & 0,14 & 0,01 & $-0,62^{* *}$ \\
ISCED 3C long & 0,00 & 0,00 & 0,00 & 0,00 & 0,00 & 0,00 \\
ISCED 3B & 0,37 & - & $0,41^{*}$ & 0,22 & 0,24 & $-0,24$ \\
ISCED 3A & - & 0,26 & - & $-0,03$ & 0,25 & $-0,69$ \\
& 0,06 & 0,12 & $0,54^{* *}$ & 0,13 & 0,58 & $-0,13$ \\
\hline
\end{tabular}

a : statistisch gecontroleerd voor leeftijd en sekse

* : $p<0,05$

**: $p<0,01$ (test van verschillen ten opzichte van ISCED3C short; per land)

- : niet van toepassing

Bron: Eurostat, EU LFS 2000, eigen berekeningen

Tabel A2

Relatieve kans op vast werk, 15-64 jarigen (logodds ratio's) ${ }^{a}$

\begin{tabular}{lcccccc}
\hline Opleidingsniveau & NL & FR & UK & GR & ES & IT \\
\hline ISCED 1-2 & $-0,40^{*}$ & $-0,34^{* *}$ & $-0,03$ & $-0,82^{* *}$ & 0,03 & $-0,37^{*}$ \\
ISCED 3C short & 0,00 & 0,00 & 0,00 & 0,00 & 0,00 & 0,00 \\
ISCED 3C long & 0,25 & - & 0,05 & 0,04 & 0,51 & $-0,42$ \\
ISCED 3B & - & 0,09 & - & $-0,42$ & 0,46 & $-0,56$ \\
ISCED 3A & 0,00 & $-0,08$ & $-0,03$ & 0,02 & 0,89 & $-0,15$ \\
\hline
\end{tabular}

a : statistisch gecontroleerd voor leeftijd en sekse

* : $p<0,05$

**: $p<0,01$ (test van verschillen ten opzichte van ISCED3C short; per land)

- : niet van toepassing

Bron: Eurostat, EU LFS 2000, eigen berekeningen

Tabel A3

Relatieve kans op voltijd werk, 15-64 jarigen (logodds ratio's) ${ }^{a}$

\begin{tabular}{lccccrr}
\hline Opleidingsniveau & NL & FR & UK & GR & ES & IT \\
\hline & & & & & \\
ISCED 1-2 & $-0,22$ & $-0,34^{* *}$ & $-0,34^{* *}$ & $-0,97$ & 0,28 & $-0,09$ \\
ISCED 3C short & 0,00 & 0,00 & 0,00 & 0,00 & 0,00 & 0,00 \\
ISCED 3C long & $-0,08$ & - & $-0,01$ & $-0,42$ & 0,17 & 0,13 \\
ISCED 3B & - & 0,41 & - & $-0,65$ & 0,50 & $-0,06$ \\
ISCED 3A & $-0,03$ & 0,12 & $0,33^{* *}$ & $-0,42$ & 0,83 & 0,21 \\
\end{tabular}

a : statistisch gecontroleerd voor leeftijd en sekse

**: $p<0,01$ (test van verschillen ten opzichte van ISCED3C short; per land)

- : niet van toepassing

Bron: Eurostat, EU LFS 2000, eigen berekeningen 
Tabel A4

Verschil in bereikt beroepsprestige, 15-64 jarigen (statuspunten) ${ }^{\mathrm{a}}$

\begin{tabular}{|c|c|c|c|c|c|c|}
\hline Opleidingsniveau & $\mathrm{NL}$ & FR & UK & GR & ES & IT \\
\hline ISCED 1-2 & $-3,70^{* *}$ & $-3,50^{* *}$ & $-6,88^{* * \# \#}$ & $-4,17^{* *}$ & $-3,89$ & $-6,18^{* * \#}$ \\
\hline ISCED 3C short & 0,00 & 0,00 & 0,00 & 0,00 & 0,00 & 0,00 \\
\hline ISCED 3C long & $4,51^{* *}$ & - & $3,05^{\star \star \#}$ & $10,85^{* * \#}$ & $10,54^{*}$ & $8,43^{* * \# \#}$ \\
\hline ISCED 3B & - & $6,39^{* *}$ & - & 1,97 & 0,93 & $6,93^{\star *}$ \\
\hline ISCED 3A & $6,78^{* *}$ & $9,14^{* * \# \#}$ & $2,97^{* * \# \#}$ & $5,21^{* *}$ & $8,06^{* *}$ & $7,65^{\star *}$ \\
\hline
\end{tabular}

a : statistisch gecontroleerd voor leeftijd en sekse

* : $p<0,05$;

$* *$ : $p<0,01$ (test van verschillen ten opzichte van ISCED3C short; per land)

\# : $\mathrm{p}<0,05$

\#\# : $p<0,01$ (test van verschillen ten opzichte van Nederland; per opleidingsniveau)

- : niet van toepassing

Bron: Eurostat, EU LFS 2000, eigen berekeningen 